\title{
AVALIAÇÃO DA RESISTÊNCIA À FRATURA DE DENTES TRATADOS ENDODONTICAMENTE COM PINOS PRÉ-FABRICADOS E RESINAS COMPOSTAS VARIANDO A QUANTIDADE DE REMANESCENTE DENTÁRIO CORONAL
}

MURILO PEREIRA DE MELO

Dissertação apresentada à Faculdade de Odontologia de Bauru, da Universidade de São Paulo, como parte dos requisitos para obtenção do título de Mestre em Odontologia - Área de Reabilitação Oral.

(Edição Revisada)

BAURU-SP

2003 


\section{AVALIAÇÃO DA RESISTÊNCIA À FRATURA DE DENTES TRATADOS ENDODONTICAMENTE COM PINOS PRÉ-FABRICADOS E RESINAS COMPOSTAS VARIANDO A QUANTIDADE DE REMANESCENTE DENTÁRIO CORONAL}

MURILO PEREIRA DE MELO

Dissertação apresentada à Faculdade de Odontologia de Bauru, da Universidade de São Paulo, como parte dos requisitos para obtenção do título de Mestre em Odontologia - Área de Reabilitação Oral.

Orientador: Prof. Dr. Accácio Lins do Valle

(Edição Revisada)

BAURU-SP

2003 


\begin{tabular}{|l|}
\hline Melo, Murilo Pereira de \\
M491a Avaliação da resistência à fratura de dentes tratados \\
endodonticamente com pinos pré-fabricados e resinas compostas \\
variando a quantidade de remanescente dentário coronal / Murilo \\
Pereira de Melo \\
Bauru, 2003. \\
138p.: il.; $31 \mathrm{~cm}$. \\
Dissertação (Mestrado) - Faculdade de Odontologia de \\
Bauru. Universidade de São Paulo. \\
Orientador: Prof. Dr. Accácio Lins do Valle \\
\hline
\end{tabular}

Autorizo, exclusivamente para fins acadêmicos e científicos, a reprodução total ou parcial desta dissertação/tese, por processos fotocopiadores e outros meios eletrônicos.

Assinatura:

Comitê de Ética da FOB

No. do Protocolo: ODON - 425 / 02

Data: 07 / 05 / 2002 


\section{MURILO PEREIRA DE MELO}

25 de julho de 1958 Nascimento

Curitiba-PR

$1978-1981$

Curso de Odontologia - Universidade Federal de Pelotas.

$1982-1983$

Curso de Especialização em Prótese dental na Universidade Federal de Pelotas.

$1993-1996$

$1994-1995$

$1995-2002$

Professor do curso Paraná de Prótese Dentária, nas disciplinas de Prótese Fixa I e II.

Professor Colaborador de Estomatologia Integral, área de concentração em Prótese Dental,do Curso de Odontologia da Universidade Estadual de Maringá.

Professor Auxiliar em Estomatologia Integral, área de concentração em Prótese Dental, do Curso de Odontologia da Universidade Estadual de Maringá.

1998-2000 Diretor de Cursos do Instituto de Pesquisa e Estudos Odontológicos do Departamento de Odontologia da Universidade Estadual de Maringá.

1999-2002 Professor do Curso de Aperfeiçoamento em Odontologia Adesiva Estética na Universidade Estadual de Maringá.

1999-2002 Professor do Curso de Especialização em Prótese Dental da Escola de Aperfeiçoamento Profissional da Associação Maringaense de Odontologia.

1999-2001 Coordenador do Curso de Aperfeiçoamento em Prótese Dental Fixa,do Curso de Odontologia da Universidade Estadual de Maringá.

$1999-2002$

Professor do Curso de Atualização em Implantes, do Departamento de Odontologia da Universidade Estadual de Maringá. 
$1999-2002$

$2001-2002$

2002

Associações
Professor do Curso de Aperfeiçoamento em Prótese Dental Fixa,do Curso de Odontologia da Universidade Estadual de Maringá.

Curso de Pós-Graduação em Reabilitação Oral em nível de Mestrado, na Faculdade de Odontologia de Bauru, USP.

Professor do Curso de Especialização em Implantes, da Faculdade de Odontologia da Universidade Estadual de Maringá.

ABO - Associação Brasileira de Odontologia - Secção do Paraná.

AMO - Associação Maringaense de Odontologia Maringá-PR. 


\section{DEDICATÓRIA}

Aos meus pais, lolanda e Gumercindo, exemplo de trabalho, dedicação, perseverança e amor;

À minha esposa Vanessa e meus filhos Júlia e Felipe, que me ofereceram como um ato de amor e confiança, apoio constante na realização deste trabalho;

Dedico a Vocês este Trabalho. 
"A VERDADEIRA VIAGEM DE DESCOBRIMENTO NÃO CONSISTE EM BUSCAR NOVAS PAISAGENS, MAS EM TER NOVOS OLHOS."

MARCEL PROUST 


\section{AGRADECIMENTOS}

A Deus, por estar presente em todos os momentos da minha vida.

Ao Prof. Dr. Accácio Lins do Valle, por sua orientação segura, pela amizade, pelos ensinamentos transmitidos, pela liberdade concedida no desenvolvimento deste trabalho e pela confiança em mim depositada.

À Prof. Dra. Maria Fidela de Lima Navarro, pessoa lluminada, que, pela competência e dedicação ao ensino fez com que o Mestrado Interinstitucional se tornasse realidade.

Prof. Newton Expedito de Moraes, idealizador do Mestrado Interinstitucional, um exemplo de vida, um verdadeiro pai.

Aos meus queridos amigos Carlos Salles e Renata Pascotto, responsáveis pelo meu ingresso na carreira docente, que, além de exemplo de competência e dedicação ao ensino, fazem do amor, humildade e respeito ao ser humano suas maiores características.

Ao mestre e amigo Luiz Fernando Alves Pereira Gastal, responsável direto pela minha formação acadêmica, que, por seu exemplo e dedicação inspirou-me a buscar constantemente o aperfeiçoamento profissional, ensinando-me acima de tudo, "como é bom tá vivo". 
Ao Sidney Kina, um amigo especial, que sempre tem me apoiado em toda iniciativa de busca ao conhecimento.

Ao Jefferson Ricardo Pereira, colega de mestrado de quem tive o privilégio de me tornar amigo, muito obrigado pelo grande auxílio na condução dos trabalhos laboratoriais e nas pesquisas.

Ao Rafael dos Santos Silva por sua amizade e companheirismo durante o período de convívio.

Aos meus colegas de Mestrado, Francisco, Raphael, Rolando, Sávio, Vagner, Clóvis, Thais, René, pela amizade que hoje se faz presente.

Ao amigo Denis, por seu apoio constante na elaboração deste trabalho.

Aos Professores da Faculdade de Odontologia da Universidade Estadual de Maringá, disciplina de prótese, que supriram minha carga horária para que pudesse realizar este trabalho. 
À Faculdade de Odontologia de Bauru da Universidade de São Paulo, pelas condições oferecidas para a execução deste trabalho.

À Universidade Estadual de Londrina e às demais associadas, principalmente à Universidade Estadual de Maringá, pela oportunidade oferecida com o Mestrado Interinstitucional.

Ao Presidente da Comissão de Pós-Graduação da Faculdade de Odontologia de Bauru da Universidade de São Paulo, Prof. Dr. José Carlos Pereira.

\section{MEUS AGRADECIMENTOS.}


Aos Professores do Departamento de Prótese Doutores Accácio Lins do Valle, Luiz Fernando Pegoraro, Milton Carlos Gonçalves Salvador, Renato de Freitas, José Henrique Rubo, Lucimar Falavinha Vieira, Paulo César Rodrigues Conti, Paulo Francischoni, Carlos dos Reis Pereira de Araújo, José Roberto Pereira Lauris, exemplos de mestres e pesquisadores, pela sua dedicação, amizade e por ensinar a importância e o verdadeiro sentido de ser professor e pesquisador.

\section{MEUS SINCEROS AGRADECIMENTOS.}




\section{SUMÁRIO}

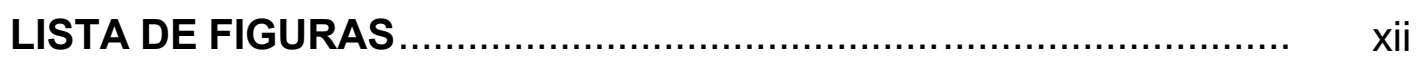

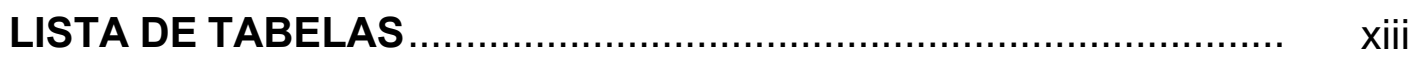

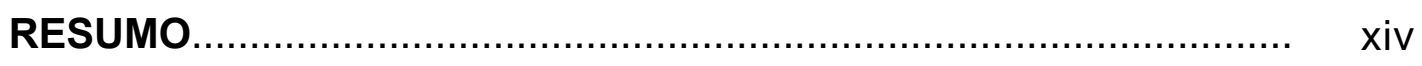

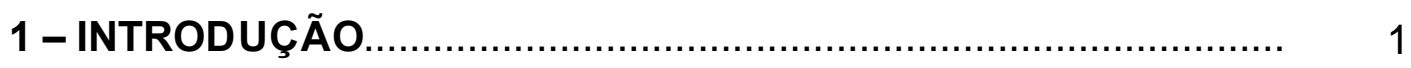

2 - REVISÃO DE LITERATURA.................................................. 6

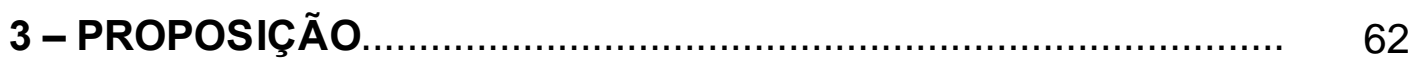

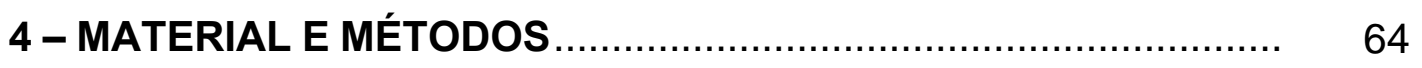

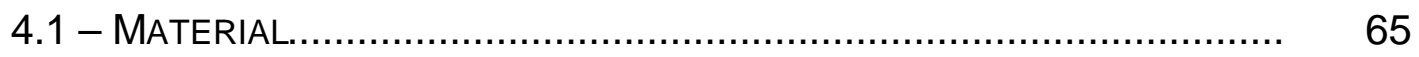

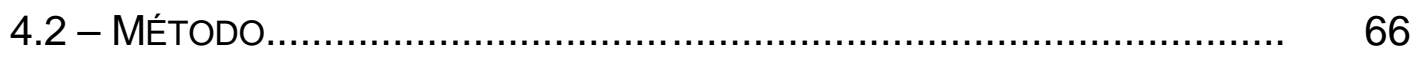

4.2.1 - SELEÇÃO dOS DENTES, LIMPEZA E ARMAZENAMENTO.................... 66

4.2.2 - TRATAMENTO ENDODÔNTICO................................................. 66

4.2.3 - DISTRIBUIÇÃO DOS GRUPOS................................................... 67

4.2.4 - PREPARO DOS DENTES............................................................ 68

4.2.4.1 - GRupos I E II COM REMANESCENTE CORONAL.......................... 68

4.2.4.2 - Grupos III E IV SEM REMANESCENTE CoRONAL....................... 69

4.3 - PREPARO DOS CONDUTOS.......................................................

4.4 - CIMENTAÇÃO DOS PINOS............................................................

4.5 - CoNFECÇÃO DOS NÚCLEOS DE PREENCHIMENTO............................ 72

4.5.1 - OBTENÇÃO dAS MATRIZES DE PLÁSTICO.....................................

4.5.2 - INSERÇÃO DA RESINA DE PREENCHIMENTO................................. 73

4.6 - INCLUSÃO DOS DENTES.........................................................

4.7 - ENSAIO DE RESISTÊNCIA À FRATURA.......................................... 75

5 - RESULTADOS

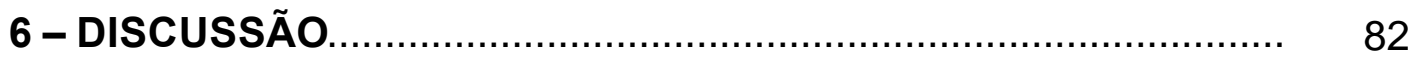

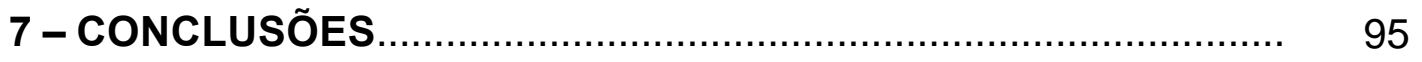

ANEXOS

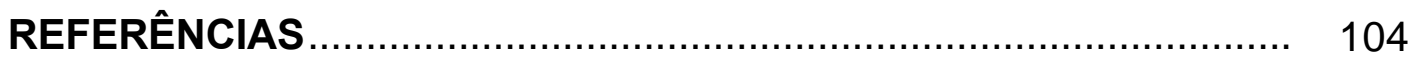

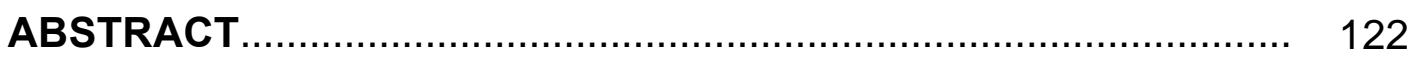




\section{LISTA DE FIGURAS}

FIGURA 1 - Preparo dos dentes com remanescente coronal

FIGURA 2 - Preparo dos dentes sem remanescente coronal - etapa de seccionamento

FIGURA 3 - Preparo dos condutos

71

FIGURA 4 - Cimentação dos pinos intra-radiculares

72

FIGURAS 5 - Confecção das matrizes de polietileno

73

FIGURA 6 - Confecção dos núcleos de preenchimento com remanescente coronal..

FIGURA 7 - Confecção dos núcleos de preenchimento sem remanescente coronal.

FIGURA 8 - Esquema da aplicação de força à 45ํㅜㄴ

FIGURA 9 - Visualização do aparato utilizado para a fixação e posicionamento dos corpos de prova submetidos ao teste de resistência à fratura em uma máquina universal de ensaios

FIGURA 10 - Representação gráfica das médias de resistência à fratura dos quatro grupos experimentais.

FIGURA 11 - Enforce Core sem remanescente coronal.

FIGURA 12 - Enforce Core com remanescente coronal

FIGURA 13 - Z-250 sem remanescente coronal.

FIGURA 14 - Z-250 com remanescente coronal. 


\section{LISTA DE TABELAS}

TABELA 1 - Materiais de consumo utilizados. .65

TABELA 2 - Valores individuais, médias e respectivos desvios-padrão para cada condição experimental 79

TABELA 3 - Teste estatístico de análise de variância a dois critérios aplicado aos valores de resistência à fratura. .80

TABELA 4 - Comparações individuais - Teste de Tukey 80

TABELA 5 - Padrão de fraturas .98 


\section{RESUMO}

O objetivo desta pesquisa foi avaliar a influência do remanescente dentário coronal de dentes tratados endodonticamente, restaurados com pinos pré-fabricados e duas resinas como núcleos de preenchimento, uma de presa dual (Enforce Core) e outra fotopolimerizável (Z-250). Foram utilizados 40 caninos superiores humanos extraídos, divididos em quatro grupos de 10 espécimes: Grupo I - com remanescente dentário coronal de $3 \mathrm{~mm}$ e restaurados com Enforce Core; Grupo II - com remanescente dentário coronal de $3 \mathrm{~mm}$ e restaurado com Z-250; Grupo III - sem remanescente dentário coronal e restaurado com Enforce Core; Grupo IV - sem remanescente dentário coronal e restaurado com Z-250. Após restaurados, os dentes foram levados a uma Máquina de Ensaio Universal e submetidos a uma força de compressão à $45^{\circ}$ até que ocorresse fratura da restauração. A análise dos resultados (ANOVA, p>0,05) mostrou não haver diferença estatisticamente significativa entre os dentes com e sem remanescente dentário coronal. Com relação ao material utilizado para o preenchimento coronário, constatou-se diferença significativa, sendo que os valores mais elevados de resistência à fratura foram encontrados no grupo restaurado com a resina fotopolimerizável.

Palavras-chave: resistência, pino, núcleo, resinas compostas. 


\section{INTRODUÇÃO}

A Reabilitação Oral tem como principais objetivos à conservação ou o restabelecimento da função e estética dos dentes. A maioria dos tratamentos protéticos realizados utiliza dentes pilares submetidos à tratamento endodôntico, recebendo núcleos metálicos fundidos $^{15,45,46,60,88,92,118}$. Este tipo de restauração, segundo muitos autores, fragiliza e torna os dentes mais susceptíveis à fratura ${ }^{19,23,24,36,73,89,123,126}$. A partir deste momento a recuperação estrutural de um dente despolpado torna-se muito importante para garantir que uma futura restauração seja bem sucedida. De acordo com AKKAYAN et al. ${ }^{2}$, o que torna ainda mais complexa a restauração destes dentes é que não existe um consenso com relação às melhores técnicas e aos materiais a serem utilizados.

Alguns métodos de restauração de dentes despolpados foram descritos há mais de cem anos. O tratamento para dentes que se encontram nesta situação tem se baseado na confecção de núcleos intra-radiculares com o propósito de reforçar o dente estruturalmente comprometido e prover retenção à futura restauração ${ }^{36,62,63,70,104,125}$.

Por outro lado, quando existe uma perda mínima de estrutura dentária a utilização do pino não se torna necessária $5,29,45,48,76,77,84,106,111,127,132$.

O método mais utilizado para a reconstrução de dentes tratados endodonticamente é os núcleos metálicos fundidos 15,47,45,60,88,118. Segundo MORGANO; MILOT ${ }^{86}$, estes núcleos possuem desvantagens relacionadas à necessidade de moldagem, de uma fase laboratorial, de duas sessões clínicas para sua confecção e à presença de imperfeições originadas durante a sua fundição. 
O aparecimento de novos materiais permitiu alternativas para 0 tratamento de dentes tratados endodonticamente como, por exemplo, a utilização de pinos intra-radiculares pré-fabricados e de material de preenchimento, tal como, as resinas compostas $9,10,41,86,78$.

Relatou BARABAN ${ }^{9}$, em 1970, que estes sistemas se apresentam com uma grande variação de formas e características superficiais, tendo sido adotados pela sua praticidade, rapidez de procedimentos de preparo do canal radicular e cimentação, todos numa única sessão.

Segundo COHEN et al. ${ }^{31}$, em 1997, a associação do pino intra-radicular pré-fabricado com resina de polimerização química, dual e fotopolimerizável e adesivos dentinários para a confecção do núcleo de preenchimento, permite uma maior preservação da estrutura dental coronária e adequada resistência.

Em 1996, MORGANO ${ }^{84}$ sugeriu que as limitações deste sistema de restauração poderiam levar à menor resistência mecânica do núcleo de preenchimento, e à falha na região do terço cervical do canal radicular,advogando mais estudos clínicos que pudessem comprovar sua eficácia e longevidade. Apesar disto, atualmente, é observada uma forte tendência para o uso de sistemas de pinos pré-fabricados em detrimento do uso de núcleos metálicos fundidos ${ }^{1,11,22,29,60}$.

Tradicionalmente, imaginava-se que pinos e núcleos metálicos deveriam proporcionar retenção da coroa protética e até reforçar o remanescente radicular ${ }^{36,47,62}$. Entretanto, esta última hipótese é contrariada por vários autores $4,47,61,63,76,77,98,105,109,110,126,127$, os quais afirmam que os pinos intra-radiculares não reforçam a estrutura dentária remanescente, mas, sim, podem enfraquecê-la 4,6,15,77,79,91,98,119,125,127.

Os profissionais, então, são colocados diante de um desafio quando necessitam restaurar dentes com canais tratados endodonticamente, e perda de estrutura dentária coronal. ASSIF; GORFIL ${ }^{5}$ e MANNING et al. ${ }^{77}$, 
afirmaram que a resistência à fratura do dente tem relação direta com a quantidade de remanescente dentário, concluindo que dentes com perda de estrutura dentária prévia devido à lesão cariosa, restauração, fratura ou acesso endodôntico exagerado são mais vulneráveis às forças que atuam sobre os mesmos.

De acordo com MONDELLI et al. ${ }^{83}$, 1980, o dente despolpado apresenta resistência diminuída principalmente pela grande perda de estrutura dentinária, tecido este resiliente que confere ao dente resistência elástica.

Alguns autores ${ }^{16,45,49,90}$ têm defendido a idéia que a preservação de remanescente dental, melhora a resistência à fratura de um dente tratado endodonticamente, em função da distribuição uniforme das forças.

Por outro lado, SORENSEN; ENGELMAN ${ }^{109}$ verificaram não existir significância nos resultados quando comparou remanescente dentário coronal e resistência à fratura.

Com o aumento do emprego de pinos pré-fabricados, em detrimento dos núcleos fundidos, o material de preenchimento tem recebido especial atenção. Tradicionalmente, os materiais empregados para restaurações eram os mesmos para o preenchimento, porém, nos últimos anos, materiais específicos para este fim foram desenvolvidos ${ }^{32,85}$.

Devem-se considerar alguns requisitos na escolha do material: estabilidade em meio úmido; facilidade de manipulação; adequado tempo de trabalho; repreparo imediato; cor; adesão ao dente/pino; resistência à fratura; força de tensão; alto módulo de elasticidade; dureza; baixa deformação plástica; inércia (sem corrosão); liberação de flúor; biocompatibilidade; baixo custo; história de sucesso clínico $7,51,83,87,107$.

Infelizmente, nenhum material de preenchimento apresenta todos estes requisitos, devendo-se considerar as necessidades funcionais do dente, sua localização no arco, quantidade de remanescente dentário, 
suporte ou não de uma prótese parcial e tempo decorrido entre o preparo e cimentação da restauração final ${ }^{107}$.

O material de preenchimento mais utilizado é a resina composta, preenchendo o maior número destas indicações ${ }^{5,15,31,87,107,123}$.

Tem-se demonstrado que as resinas compostas possuem adequada resistência à compressão e à fratura ${ }^{6,10,24,31,41}$. A excelente capacidade de adesão das resinas compostas, quando empregadas em conjunto com os sistemas adesivos de última geração, promovem, entre as estruturas dentárias e o pino, melhor retenção, criando dessa forma,um corpo único. Em 1998, ZALKIND; HOCHMAN ${ }^{132}$ aconselham o uso da resina composta como material de preenchimento somente quando houver bom suporte dentinário, não sendo indicada quando há perda total do remanescente coronal.

A presença de novos materiais e a escassez de informações faz lícita a realização deste trabalho, a fim de elucidar aspectos de resistência a fratura de dentes tratados endodonticamente com e sem remanescente coronário associados à pinos intra-radiculares pré- fabricados, e núcleos de preenchimento em resina composta. 
2 REVISÃO DE LITERATURA 


\section{REVISÃO DE LITERATURA}

BOVE, em 1941 (apud VALLE ${ }^{128}$ ) relatou que, por volta de 1840, na Inglaterra, dentes com formato de tubos com perfurações em toda a sua extensão,associados a espigas de madeira, eram utilizados para a restauração de dentes despolpados. Citou ainda que CLARK, em 1844, substituiu o tubo de madeira por um de metal, alegando um aumento na resistência da restauração.

A utilização de coroas tipo "espiga" ou "pivôs" foram predominantemente utilizadas até os anos 60. Apresenta porém grande dificuldade de emoção devido ao risco de fratura de raiz e obtenção de paralelismo.

MARKLEY ${ }^{78}$, em 1958, propôs a utilização de pinos para retenção de reconstruções com amálgama. Segundo o autor, o amálgama bem condensado apresenta resistência à compreensão comparável com a da dentina, podendo ser utilizado também na confecção de núcleos de preenchimento para sustentar uma restauração indireta. Assim, a associação de pinos intradentinários ou intra-radiculares e reconstruções com amálgama pode ser um método utilizado para salvar dentes, ou raízes que comumente seriam sacrificadas.

ROSEN ${ }^{101}$, em 1961, preocupou-se em estabelecer normas para a correta reconstrução de dentes fragilizados e tratados endodonticamente, realizando uma ampla revisão de literatura, alertando que a perda de umidade decorrente do tratamento endodôntico, torna a dentina friável e inelástica. Além disso, considera a facilidade com que esses dentes desenvolvem lesões periapicais. Recomendando procedimentos que reforcem o dente, indica a confecção de núcleos metálicos fundidos e coroa 
protética abraçando o término gengival, prevenindo com isso a ocorrência de fraturas sob cargas mastigatórias, o que pode resultar no aumento da sua longevidade.

SILVERSTEIN ${ }^{104}$, em 1964, relatou as vantagens da confecção de um núcleo intra-radicular quando comparado a uma coroa com espiga, salientando a importância do núcleo não ser parte integral da coroa. Descreveu, também, uma técnica direta para a obtenção de núcleos metálicos a partir de um padrão de fundição, confeccionado pela moldagem do conduto com um pino de resina acrílica e cera, e a obtenção da porção coronária pelo auxilio da coroa provisória.

Em 1967, CHRISTY; PIPKO ${ }^{27}$, verificaram que uma coroa cimentada sobre um núcleo em dois estágios, pino e núcleo de preenchimento, seria o o tratamento adequado para um dente tratado endodonticamente, preenchendo os princípios biomecânicos de desenho, função e estética, além de dispender pouco tempo clínico e ser um procedimento simples. Os autores afirmaram que se deve preservar a estrutura dentária ao máximo ao preparar a porção radicular para receber o pino metálico e este poderia atingir de dois terços a três quartos do remanescente radicular.

Em 1970, BARABAN ${ }^{9}$, escreve sobre a utilização de pinos préfabricados Para-post, em dentes tratados endodonticamente, enfatizando vantagens do uso do método direto e de pinos metálicos confeccionados em ouro, aço inoxidável, plástico e alumínio. Os pinos de ouro e aço eram serrilhados para que houvesse maior retenção do cimento e cuidado especial deveria ser tomado para se evitar formação de bolhas de ar, causando desajustes nos pinos e até fraturas. A maior vantagem deste sistema é a obte nção de pinos e núcleos pelo método direto permitindo que todo o procedimento seja feito em uma única sessão.

Em 1972, BARABAN ${ }^{10}$ preconizou a utilização do sistema Para-post e a fabricação do núcleo de preenchimento, com resina composta ativada quimicamente, para reconstrução da porção coronária em dentes uni e 
multirradiculares. Este tratamento economizaria tempo e material permitindo, ainda, o preparo imediato do dente, dispensando o trabalho de laboratório. $O$ autor enfatiza a existência de suficiente retenção entre o núcleo de preenchimento e pino intra-radicular de resina durante os procedimentos subseqüentes e durante a função, não existindo mais a necessidade do uso de núcleos metálicos fundidos.

Para PEREL; MUROFF ${ }^{88}$, em 1972, o preparo do acesso cavitário para tratamento endodôntico leva à remoção de estrutura dentária, predispondo o dente às fraturas. Para sanar este problema indicaram o uso de um núcleo reforçando o conjunto raiz e porção coronária. Dentre os requisitos para o sucesso de tratamento com núcleos fundidos salientaram: 1) o pino deverá ser longo para prevenir o esforço interno excessivo na raiz; 2) o assentamento oclusal previne a ação de cunha, eliminando possível fratura da raiz; 3) a boa adaptação interna do pino distribuirá os esforços internos em toda sua extensão, além de proporcionar uma fina camada de cimento. Enfatizaram o perigo do uso de pinos rosqueados, como maior incidência de fratura à nível radicular.

STANDLEE et al. ${ }^{115}$, em 1972, analisaram três tipos de núcleos resumindo suas vantagens e desvantagens: 1) os núcleos lisos, paralelos, são bastante retentivos, porém de difícil cimentação devido à pressão hidrostática; 2) os núcleos lisos, de forma cônica distribuem melhor o cimento, porém são os menos retentivos; 3) núcleos rosqueados com paredes paralelas são os mais retentivos, porém de difícil execução clínica. Os núcleos foram cimentados com cimento de fosfato de zinco, introduzidos no canal com broca Lentulo; o pino era recoberto com cimento, e o assentamento feito digitalmente; para evitar seu deslocamento durante a cimentação, recomendaram a confecção de um sulco de escape ao longo do pino. Após a realização de uma análise fotoelástica da distribuição das forças durante a cimentação dos núcleos concluíram: a) o axioma clínico de que o comprimento do pino deva aproximar-se do comprimento da coroa anatômica para melhor distribuição de forças parece verdadeiro, visto que 
ocorreu uma redução na concentração de esforços com aumento do comprimento do pino; b) os núcleos rosqueados proporcionam melhor distribuição de esforços quando em pequenos comprimentos; c) os núcleos cônicos exibiram um efeito de cunha e produziram maior concentração de esforços na área cervical; d) os núcleos de paredes paralelas geraram as mais altas concentrações de forças apicais.

Preocupados com o alto índice de fraturas radiculares de dentes tratados endodonticamente e reconstruídos com núcleos metálicos fundidos STERN; HIRSHFIELD ${ }^{118}$, em 1973, observaram e afirmaram que estes dentes têm sua resistência diminuída e para que isto fosse minimizado alguns princípios durante os preparos dos condutos deveriam ser seguidos. Segundo os autores, a profundidade do núcleo intra-radicular deve atingir cinqüenta por cento da distância entre o ápice radicular e a crista óssea alveolar para diminuir os fatores de risco.

A técnica de obtenção de núcleos de preenchimento com resinas compostas, após cimentação de pinos pré-fabricados no conduto, foi descrita por FEDERICK ${ }^{41}$, em 1974, afirmando ser esta uma técnica precisa, econômica e que tem apresentado sucesso em diversas situações clínicas.

FARAH e CRAIG ${ }^{40}$, em 1974, realizaram um trabalho de análise fotoelástica tridimensional de tensões produzidas por três configurações de término marginal para coroas protéticas. Foram comparados os términos do tipo ombro, chanfrado e lâmina de faca. A análise do estresse observado nos modelos demonstrou um padrão de distribuição de tensões semelhante em relação ao término em forma de ombro e lâmina de faca, porém com diferença estatística em relação ao término em chanfrado, que demonstrou a menor concentração de tensões. Diante disso, os autores concluíram que a mudança de configuração do término do preparo pode modificar a distribuição de tensões sobre o dente, e que o preparo tipo chanfrado proporcionou os melhores resultados. 
STAHL; O’NEAL ${ }^{116}$, em 1975, realizaram um estudo clínico e laboratorial para determinar a possibilidade de utilizar resina composta para a confecção de pinos e núcleos. Descreveram um caso clínico onde era feito o preenchimento do canal radicular com resina, a qual era inserida com auxílio de uma seringa, e a porção coronária do núcleo obtida pelo mesmo material com auxílio de uma coroa de policarboxilato e resina composta. A investigação laboratorial teve por objetivo verificar diferentes métodos de inserção da resina, tendo sido aconselhável a utilização de seringa para obtenção de núcleos livres de bolhas. Os autores concluíram que, embora houvesse necessidade de avaliações futuras, estudos preliminares demonstravam que esta nova técnica preenchia os objetivos de saúde, função e estética.

JOHNSON et al. ${ }^{60}$, em 1976, analisaram vários métodos e técnicas capazes de proteger a estrutura dental remanescente de fraturas, proporcionando melhor retenção e suporte às restaurações em dentes tratados endodonticamente. Afirmaram que os núcleos fundidos são mais resistentes às forças horizontais e verticais e quando de sua inserção dentro do conduto as forças transmitidas à raiz não levam a fraturas. Sugeriram que os núcleos fundidos deveriam estar perfeitamente adaptados aos condutos, pois permitiriam uma distribuição uniforme de forças mastigatórias. 0 cimento deveria ser levado ao conduto por meio de uma broca Lentulo, para evitar a presença de bolhas de ar, obtendo-se uma camada uniforme do mesmo. Aconselharam a confecção de sulcos de escape ao longo dos núcleos, o que permitiria um melhor assentamento, contribuindo para um melhor escoamento do excesso de cimento.

CAPUTO; STANDLEE ${ }^{19}$, em 1976, ressaltaram que, além da importância da retenção do pino, há necessidade de preservar e proteger a dentina remanescente e a estrutura dentária. Os autores consideraram a utilização de núcleos intra-radiculares como uma técnica radical e, caso houvesse erros, poucas soluções corretivas poderiam ser empregadas. Destacaram que a maior retenção é dada com aumento do comprimento do 
conduto, mas, como fator de risco, acontece o enfraquecimento da raiz. Concluíram que pinos com paredes paralelas, serrilhadas e cimentados com fosfato de zinco seria a melhor combinação para o sucesso da prótese.

BRAVIN $^{16}$, em 1976, analisou o comportamento de quatro sistemas de núcleos pré-fabricados como reforço e um grupo-controle (dentes íntegros) em incisivos laterais submetidos a cargas funcionais. Os pinos foram cimentados com cimento de fosfato de zinco, com profundidade de 7 a $10 \mathrm{~mm}$, submetidos a forças oblíquas, cujos valores eram registrados quando ocorria a fratura do dente. Verificou que as fraturas do grupo-controle sempre permitiam reparações e ocorriam sob ação de forças muito mais altas, enquanto os dentes com pinos sofriam fraturas irreparáveis. Concluiu que: 1) nenhum dos pinos testados reforça os dentes e podem, ao contrário do que se pensava, enfraquecê-los; 2) o comprimento do pino foi estatisticamente significante - quanto mais longo, maior a retenção; 3) a espessura de dentina remanescente entre o ápice do pino e à superfície dental mesial e distal, foi estatisticamente significante em relação á fratura dental; 4) se um pino for necessário, o Para-post em uma profundidade ideal foi o melhor de todos os testados; 5) o uso de pinos para suportar um dente restaurado endodonticamente tem um potencial de fracasso.

Estudando diferentes técnicas nas restaurações de dentes despolpados, KANTOR; PINES ${ }^{62}$, em 1977, utilizaram dentes unirradiculares reunidos em quatro grupos: 1) grupo-controle preparo do dente sem reforço; 2) dente reforçado com pino de aço inoxidável, fixado ao conduto com cimento de policarboxilato; 3) núcleo metálico fundido em ouro e cimentado com cimento de policarboxilato; 4) pino de aço inoxidável cimentado com policarboxilato e porção coronária de resina composta. Estes pinos foram submetidos a uma força de compressão em 45ํ na superfície vestibular, até que ocorresse a fratura. Concluíram que em dentes com a porção coronária intacta devido a uma boa terapia endodôntica, um pino cimentado dentro do conduto seria o tratamento de escolha, acreditando que a resistência do 
dente seria dobrada. Indicaram o uso de pinos metálicos fundidos para tratamentos complexos protéticos e pacientes periodontais.

Em 1977, HENRY e BOWER ${ }^{50}$ estudaram, por meio de análise fotoelástica, formas diferentes de pinos intra-radiculares e sua correlação antes e após a aplicação de carga quanto ao stress gerado. Verificaram os pinos com: 1) paredes divergentes; 2) paredes paralelas; 3) paredes paralelas e rosqueadas; 4) paredes divergentes rosqueadas. Observaram que, antes da aplicação de carga, os pinos cônicos e de paredes paralelas permaneceram sem áreas de concentração de força. Após a aplicação de carga, os pinos com paredes paralelas mostraram concentração de força em ambos os lados e os cônicos na região apical. Os de parede paralela foram mais favoráveis que os cônicos e os rosqueados apresentaram concentração de esforços tão grande que o autor considerou duvidosa sua aplicação clínica. Verificou, também, que a concentração de esforços diminuía quando existia um pequeno remanescente coronário, deixando a sugestão de que este deva ser mantido quando formos confeccionar um núcleo.

Em 1978, TRABERT; CAPUT; ABOU-RASS ${ }^{125}$ realizaram um estudo para analisar a resistência de dentes tratados ou não endodonticamente e restaurados com o uso de pinos de aço inoxidável. Foram utilizados pinos de diâmetro, largura e comprimentos diferentes. Verificaram que os pinos com diâmetros menores preservam a estrutura dentária, aumentando significativamente a resistência à fratura.

Objetivando provar a capacidade retentiva de pinos intra-radiculares, STANDLEE; CAPUTO-HANSON ${ }^{117}$, em 1978, empregaram tipos diferentes de cimento, técnicas de cimentação, comprimento, desenho e diâmetro do núcleo pré-fabricado. Foram utilizados em experiências de resistência à tração três diferentes configurações de pinos: cônico, paralelo serrilhado e paralelo rosqueado; e três diferentes tipos de cimentos: fosfato de zinco, carboxilato e resinoso. Concluíram que os pinos paralelos rosqueados são mais retentivos que os cônicos; e que quanto maior o comprimento do pino 
maior a retenção. Quanto ao diâmetro dos pinos, não se encontrou aumento significativo de retenção; e os cimentos resinosos apresentaram melhor comportamento de retenção.

MILLER $^{82}$, em 1978, através de um artigo, descreveu uma técnica para confecção de núcleos metálicos fundidos através de confecção de um padrão de resina acrílica na cavidade bucal. Ele entende que o núcleo deve ter uma conicidade mínima, evitando desgaste de estrutura dental. Afirma que este método resulta em menor remoção de dentina do que quando se utilizam pinos pré-fabricados cilíndricos, que diferem da anatomia do canal, resultando em remoção de dentina na porção mais apical do preparo.

JOHNSON; SAKAMURA ${ }^{59}$, em 1978, estudaram a resistência a tração de pinos pré-fabricados em função da variação da sua forma, comprimento e diâmetro. Sessenta incisivos centrais humanos foram selecionados e divididos em grupos experimentais para receberem pinos paralelos e cônicos com 7,9 e $11 \mathrm{~mm}$ de comprimento. Para cada comprimento, os pinos ainda variaram em diâmetro, entre 0,8 e 1,2mm na parte apical do pino. Os resultados demonstraram que os pinos com $11 \mathrm{~mm}$ de comprimento foram significativamente mais retentivos que os pinos com 7 ou $9 \mathrm{~mm}$ de comprimento, que não diferiram entre si. O maior diâmetro resultou em maior resistência à tração. Porém, os autores sugerem que a retenção deve ser, principalmente, confeccionada às expensas do comprimento do pino, preservando a estrutura dentinária do canal radicular, comparados os pinos cônicos com os paralelos, para remover estes últimos foi necessário 4,5 vezes mais força. Relataram que a falha em relação aos pinos cônicos, localizourse principalmente entre o pino e o agente de cimentação. Para os paralelos, parte do agente de fixação é retida pelas roscas do pino e a fratura, quando acontece, ocorre entre a espessura do cimento, requerendo maior força para sua remoção.

Em 1979, GUZY; NICHOLLS ${ }^{47}$ avaliaram o reforço da estrutura dental decorrente da utilização de pinos em dentes tratados endodonticamente. Foram selecionados 59 dentes recentemente extraídos, incisivos centrais e 
caninos, os quais tiveram seus condutos radiculares preenchidos com gutapercha, pela técnica da condensação lateral. Vinte e nove desses não utilizavam pinos intra-radiculares e tiveram suas câmaras pulpares até $2 \mathrm{~mm}$ abaixo da junção cemento-esmalte preenchida com cimento de silicato. $O$ restante dos dentes recebeu pinos intra-radiculares, com remoção do material restaurador intracanal até $8 \mathrm{~mm}$. Pinos intra-radiculares "Kerr Endo-post" bram cimentados com cimento de fosfato de zinco, os dentes colocados em cilindros de alumínio preenchidos com resina acrílica, montados em um ângulo de 130 em relação ao longo do eixo do dente; em seguida, aplicou-se uma força teste Istron. O resultado encontrado mostrou que não houve diferença estatística significativa quando da utilização ou não de pinos intra-radiculares.

MONDELLI et al. ${ }^{83}$, em 1980, estudaram a resistência à fratura de pré-molares, onde variavam a amplitude vestíbulo-lingual de 3 tipos de preparo: oclusais, próximo-oclusais com duas faces e preparos MOD. Para realizar a pesquisa, utilizaram-se 100 pré-molares recém extraídos de pacientes com idade entre 20 e 25 anos. Foram divididos 30 dentes para cada tipo de cavidade, onde 3 diferentes diâmetros de preparo eram confeccionados para cada grupo de 10 dentes. O grupo-controle foi composto por 10 dentes hígidos. Após a divisão e a realização dos preparos, foram incluídos em blocos de resina e submetidos à fratura, sob carregamento de compressão, a uma velocidade de $0,5 \mathrm{~mm}$ por minuto. Uma esfera com $4 \mathrm{~mm}$ de diâmetro contatava ambas as cúspides dos pré-molares, simulando uma carga oclusal. Concluiu-se que todas as cavidades são capazes de diminuir a resistência dos dentes e que a amplitude da cavidade está diretamente relacionada à resistência à fratura do remanescente dental.

CHRISTIAN et al. ${ }^{26}$, em 1981, selecionaram 25 molares inferiores intactos recém-extraídos, cortaram a coroa $2 \mathrm{~mm}$ acima da junção amelocementária e montaram em um cilindro de resina acrílica. Os dentes foram divididos em 3 grupos: a) dentes íntegros; b) núcleos de amálgama sem pinos e c) núcleos de amálgama com pinos intra-radiculares. Os dentes 
foram montados em uma máquina Instron, com uma angulação de incidência de força de $90^{\circ}$. Ao final dos testes, os autores encontraram que os dentes hígidos foram os mais resistentes (269 libras) seguidos pelos núcleos de amálgama com pinos intra-radiculares (142 libras) e os núcleos de amálgama sem pinos intra-radiculares.

Salientando que a principal função de um pino é proteger um dente enfraquecido contra fratura, CHAN; BRYANT ${ }^{23}$, em 1982, publicaram uma investigação científica com o intuito de comparar a resistência à fratura e as características de falha de dentes posteriores tratados endodonticamente. Os materiais usados foram ouro fundido, amálgama com pino e resina composta com pinos. Os pinos foram colocados em 55 pré-molares inferiores, a uma profundidade de 8 milímetros e 0,06 polegadas de largura. Os dentes, 24 horas após confeccionados os núcleos, foram preparados e moldados para confeccionar uma coroa total fundida. Os dentes foram montados em cilindros de acrílico e colocados em uma máquina de ensaios para medir a resistência ao cisalhamento. Após realizados os testes verificourse que os núcleos fundidos em ouro necessitaram de menor força para se deslocarem do conduto e a maioria deles apresentaram fratura da raiz. Espécimes de amálgama e resina apresentaram fratura do núcleo mas menor evidência de deslocamento do núcleo, sendo que os núcleos de resina composta não mostraram tão freqüentes fraturas da raiz como nos núcleos de amálgama. Os autores concluíram que os núcleos de preenchimento de resina composta e amálgama são alternativas altamente aceitáveis e a superioridade destas se deve provavelmente a rigidez dos postes de aço e a adaptação superior do amálgama e resina composta em relação aos núcleos fundidos.

HOAG; DWYER ${ }^{53}$, em 1982, avaliaram três formas de reconstrução com retentores intra-radiculares em dentes posteriores: com ouro fundido, com amálgama e com resina composta; avaliaram também o efeito da coroa total metálica nestes três tipos de núcleos. Selecionaram 40 molares inferiores e os dividiram em 3 grupos: a) núcleo fundido em ouro; b) núcleo 
de resina composta com pino intra-radicular e c) núcleo de amálgama condensado $4 \mathrm{~mm}$ dentro dos canais. Metade dos dentes receberam uma coroa total e a outra não. Com o intuito de simular as forças de mastigação os dentes foram montados em ângulo de 45ํe em uma máquina de ensaios para cizalhamento. Nos grupos sem coroa total, os núcleos fundidos foram bem superiores aos núcleos de preenchimento sendo que amálgama e resina composta apresentaram o mesmo resultado. Os grupos com coroas foram bem mais resistentes que os sem coroa. Nos grupos com coroa total não houve diferença entre os tipos de núcleos. Como conclusão, os autores indicaram que o método de núcleo pode não ser significante se a coroa fundida tiver suas margens integralmente adaptadas além do núcleo.

A fim de conhecer as possíveis conseqüências da presença de um pino intra-radicular em dentes tratados endodonticamente, MATTISON ${ }^{80}$, em 1982, utilizou a análise fotoelástica. Esta análise serviu para comparar fotograficamente o estresse gerado após a sobrecarga de pinos fundidos em ouro com 2 diâmetros diferentes e núcleo de resina composta. Três principais conclusões foram obtidas: o diâmetro do pino reconstruído com resina composta altera a magnitude do estresse; estresses geralmente aumentam quando o diâmetro do pino aumenta; o estresse aumenta quando as cargas verticais aumentam. MATTISON ${ }^{80}$ aconselhou a diminuição do diâmetro do pino usado, particularmente quando grandes forças oclusais são exercidas pelo paciente. $\mathrm{O}$ uso de pinos de diâmetros menores reduz 0 estresse exercido sobre a dentina e estruturas de suporte e limita a quantia de material dentário removido durante o preparo.

No ano de 1983, DEUTSCH et al. ${ }^{36}$, publicaram uma revisão da literatura disponível no início daquela década referente à avaliação dos núcleos intra-radiculares pré-fabricados que eram utilizados nas restaurações de dentes. Seus estudos mostraram que os núcleos intraradiculares apresentam duas principais funções: primeiro, a de reforçar a porção coronária e a porção radicular do dente contra fratura, no caso de existência suficiente de estrutura coronária; segundo, é que, na falta de uma 
quantidade considerável da estrutura coronária, o núcleo é utilizado para repor esta falta, além de reter e suportar a restauração protética subseqüente.

BENDER; FREEDLAND ${ }^{13}$, em 1983, discorreram sobre a ocorrência de fratura radicular causada por oclusão traumática, procedimentos iatrogênicos e causas patológicas. Nove casos clínicos foram acompanhados; o tipo mais comum de fratura vertical da raiz foi causado após processos iatrogênicos, devido à tratamentos que utilizam instrumentos que provocam a remoção excessiva de estrutura dental para o acesso endodôntico e também o alargamento excessivo do canal, ocasionando o enfraquecimento da raiz.

PETERS et al. ${ }^{89}$, em 1983, através da análise de elementos finitos, analisaram as tensões geradas por pinos intra-radiculares de comprimento, forma e diâmetros diferentes, em dentes tratados endodonticamente e restaurados com coroa protética. Avaliaram, também, o efeito da espessura da camada e tipo de cimento. Concluíram que: os pinos com diâmetro menor concentram maior esforço sobre as paredes do canal radicular; quanto à forma, descobriram que, independente da forma, as tensões concentram-se principalmente nas suas terminações apicais e maior intensidade em pinos cônicos; com relação aos tamanhos, que pinos cilíndricos longos são os mais aconselhados e devendo-se respeitar os limites da raiz.

SORENSEN; MARTINOFF ${ }^{111}$, em 1984, fizeram um estudo correlacionando à parte clínica e laboratorial de 1273 dentes tratados endodonticamente, para determinar a importância clínica de reforço do pino e da cobertura coronal, bem como a importância da localização do dente no arco durante o planejamento. Concluíram que não existiu aumento significante na resistência à fratura ou ao deslocamento obtido œm reforço intracoronal para os 6 grupos anatômicos de dente; a cobertura coronal não aumentou significativamente a taxa de sucesso clínico de dentes anteriores, superiores e inferiores; a taxa de sucesso clínico foi significativamente aumentada com cobertura coronal nos pré-molares e molares superiores e 
inferiores. Opinam, então, que o recobrimento da estrutura dentária seja mais eficiente no reforço do elemento dentário do que a fabricação de um núcleo para tais dentes. No caso de uma real necessidade de núcleos intraradiculares o comprimento, a forma, o tipo de superfície e o diâmetro devem ser observados atentamente. Não foi encontrada diferença, estatisticamente significativa, quando comparadas as porcentagens de sucesso dos dentes anteriores superiores restaurados com ou sem pinos intra-radiculares. Salientam, ainda, que pinos intra-radiculares não devem ser indicados com 0 propósito de reforçar a estrutura remanescente, pois, o espaço para o pino pode levar à remoção excessiva de estrutura dentária.

Ainda no mesmo ano, SORENSEN; MARTINOFF ${ }^{112}$, correlacionaram os 1273 casos de dentes tratados endodonticamente para investigar o significado de determinados fatores como desenho, comprimento, configuração da superfície, diâmetro na confecção de núcleos intra-radiculares e suas sobrevidas. As variáveis avaliadas foram: 1) método de reforço intracoronário nas categorias: a) núcleos metálicos fundidos; b) Para-post e núcleo de preenchimento de amálgama ou resina composta; c) núcleos metálicos fundidos de Para-post; d) pinos rosqueados; e) Amalgamapin; f) pino dentinário com resina composta; 2) tamanho do núcleo intra-radicular determinado através de radiografia; 3) modo de falha, dividido em dois grupos: os restauráveis por falha de deslocamento e os não restauráveis por falhas originadas de fraturas obliquas e horizontais, fratura vertical do dente e perfuração iatrogênica do dente. Ao final do estudo, concluiurse que: pinos serrilhados cilíndricos fundidos com porção coronária e pinos serrilhados cilíndricos com porção coronária em amálgama ou resina composta registraram os resultados mais satisfatórios; pinos cônicos fundidos com porção coronária, apresentaram maior risco de falha do que os de dentes tratados sem reforço intra-coronário; pinos serrilhados não apresentaram falhas causadas por fratura dental; dentes com comprimento de pino igual ou maior que o tamanho da coroa, apresentaram percentual de sucesso superior a noventa e sete por cento. 
Em um estudo realizado por LINDHE $^{69}$, em 1984, o autor avaliou 51 dentes restaurados com pinos pré-fabricados e núcleos de preenchimento em resina composta após 10 anos, e encontrou 43 destes funcionando satisfatoriamente, e um onde a coroa foi perdida de seu núcleo. A falha dos outros sete dentes foi por fratura radicular, cárie secundária e/ou retenção do pino inadequada.

Com o objetivo de comparar a resistência à compressão de dentes posteriores tratados endodonticamente após diferentes formas de núcleos, GELFAND; GOLDMAN; SUNDERMAN ${ }^{45}$, em 1984, selecionaram 156 dentes molares superiores e inferiores divididos em 6 grupos: 1) núcleo de amálgama com 2 pinos Para-post; 2) núcleo de resina composta com 2 pinos Para-post; 3) núcleo de amálgama com o mesmo condensado dentro de 3 canais; 4) núcleo de resina composta condensado dentro de 3 canais; 5) núcleo fundido com pino em um canal e 6) dente natural com "Cavit" dentro da câmara pulpar. Destes 156 dentes, metade recebeu uma coroa total fundida e a outra metade não. Os dentes foram montados em blocos de resina acrílica e colocados sob uma angulação de 45em uma máquina de testes Instron. Após os testes, os autores concluíram que quando se coloca uma coroa total não há diferença nos resultados de resistência à compressão. Nos dentes sem coroas, os núcleos de amálgama e resina composta condensados $3 \mathrm{~mm}$ dentro dos canais foram mais resistentes do que os mesmos com pinos Para-post $7 \mathrm{~mm}$ dentro dos canais. Os núcleos fundidos foram os mais resistentes nos grupos que não receberam coroa total.

TJAN; WANG ${ }^{123}$, em 1985, desenvolveram um estudo sobre a resistência de raízes com conduto preparado com tamanhos proporcionais às várias espessuras de dentina e os fatores biomecânicos que afetam a capacidade de proteção da estrutura dentinária remanescente e o poder de retenção da restauração. Comprimento, diâmetro, configuração, saliências na superfície e o material utilizado podem afetar a resistência e retenção de um núcleo. Além destas variáveis, a espessura do cimento foi avaliada. A 
conclusão foi que núcleos com paredes paralelas seriam mais retentivos do que os núcleos cônicos. Quanto mais longo e largo é o núcleo, maior é a sua resistência e retenção; mas o alargamento excessivo do conduto pode enfraquecer a raiz por perda de dentina e causar fratura radicular. Com relação à espessura dentinária foram experimentadas as de $1 \mathrm{~mm}, 2 \mathrm{~mm}$, $3 \mathrm{~mm}$ e $1 \mathrm{~mm}$ com término cervical em bisel de 60․ $\mathrm{O}$ resultado mostrou que as raízes com $1 \mathrm{~mm}$ de espessura na parede vestibular são mais propensas à fratura.

Segundo HALPERN ${ }^{48}$, em 1985, o planejamento e o diagnóstico são de grande importância para o sucesso de qualquer procedimento odontológico. Dentre os materiais para reconstrução ter-se-ia o amálgama, a resina composta e os materiais fundidos. Após o tratamento endodôntico, dever-se-ia indicar o uso de pinos para reforço do amálgama e da resina composta, o que evitaria a fratura do dente por proporcionar apoio interno. Os pinos cimentados ou rosqueados seriam melhor utilizáveis nas seguintes situações: 1) quando a estrutura mínima da coroa do dente é removida; 2) quando um pino dentinário de prata preexistente não pode ser removido; 3) quando a retenção adicional é necessária; 4) quando a morfologia da raiz não permite o preparo de pino adequado.

Em 1985, IRVIN et al. ${ }^{57}$ avaliaram, através de uma análise fotoelástica, o padrão de estresse induzido pela inserção de pinos retentivos auto-rosqueáveis e observaram que o rosqueamento de 1/4 até meia volta resulta numa significativa diminuição do estresse gerado. Foi notada também zona de grande estresse quando estes pinos foram inseridos completamente no canal preparado, levando a uma correlação com a presença de trincas ou fendas na estrutura dentária.

A análise da relação entre o tamanho da raiz, o tamanho do núcleo e a possibilidade de fratura radicular durante a inserção de núcleos pré-fabricados, foi analisada por DEUTSCH et al. ${ }^{37}$, no ano de 1985 . Foram utilizados três sistemas diferentes de pinos pré-fabricados em 212 dentes, considerando-se morfologia radicular, comprimento, diâmetro, forma, tipo de 
rosqueamento, forma do pino, distribuição da dentina remanescente e quantidade de força durante a inserção; chegourse à conclusão de que núcleos pré-fabricados, rosqueados e cônicos apresentam maior incidência de fratura,e que dentes menores apresentam mais complicações durante a inserção do núcleo.

Questionando se um pino intra-radicular realmente reforça um dente tratado endodonticamente, TROPE; MALTZ; TRONSTAD ${ }^{127}$, em 1985, compararam a resistência à fratura de incisivos centrais superiores tratados endodonticamente sob diferentes métodos de restauração. 64 dentes foram divididos em 7 grupos: 1) com câmara pulpar preenchida com resina composta; 2) com câmara pulpar condicionados com ácido e preenchidos com resina composta; 3) com conduto preparado $10 \mathrm{~mm}$ e deixado vazio; 4) com câmara pulpar e $10 \mathrm{~mm}$ dentro do canal apenas preenchidos com resina composta; 5) com pino Para-post cimentado no canal e câmara pulpar preenchida com resina composta; 6) com pino Para-post cimentado com fosfato de zinco no canal, câmara pulpar condicionada com ácido e preenchida com resina composta; 7) com canal radicular e câmara pulpar condicionados com ácido, pino Para-post cimentado com resina composta. Os dentes foram montados em um ângulo de $50^{\circ}$ e a resistência à fratura foi medida em uma máquina Instron. Ao final, resultou o seguinte: não se encontrou nenhuma melhoria na resistência dos dentes após 0 condicionamento ácido da dentina; o preparo do conduto para um poste diminuiu significativamente a resistência do dente; a cimentação de um pino intra-radicular enfraqueceu o dente tratado endodonticamente.

PLASMANS et al. ${ }^{92}$, em 1986, compararam a resistência sob forças oblíquas de núcleos metálicos fundidos, amálgama com pino unimetric, amálgama sem pino e amalgama pin. Os núcleos foram confeccionados em dentes naturais montados em um plano inclinado de 45, com o intuito de simular forças de compressão ou cisalhamento exercidas por um dente antagonista. Após os testes, os autores concluíram que apesar da resistência superior dos núcleos fundidos, os núcleos de amálgama 
apresentam um comportamento satisfatório em casos onde o dente não está sujeito às forças além do normal como retentor de prótese fixa em se tratando de pacientes com bruxismo. Concluíram, também, que a colocação de um pino intra-radicular em núcleos em amálgama não aumentou a resistência dos dentes despolpados.

BEN-AMAR et al. $^{12}$, em 1986, testaram a retenção de um pino pré-fabricado, cimentado no interior do canal radicular através de agente resinoso, combinado a dois diferentes sistemas adesivos dentais. Selecionaram 63 raízes de incisivos, caninos e pré-molares, para a remoção da coroa e do ápice radicular, padronizando o comprimento do canal em $7 \mathrm{~mm}$. As raízes foram divididas em três grupos, que receberam o pino dentatus n.4, cimentado através da resina Silar, precedida da aplicação do sistema adesivo Scotchbond no primeiro grupo e do sistema adesivo de esmalte Concise no segundo grupo. No grupo-controle não foi aplicado sistema adesivo. Os resultados demonstraram que o agente adesivo Scotchbond foi significativamente mais retentivo que o agente adesivo de esmalte Concise e o grupo-controle; estes últimos não diferiram entre si. Os autores indicam o uso de sistema adesivo dentinário para dimentação de pinos intra-radiculares.

KAYSER; LEEMPOEL; SNOEK ${ }^{63}$, em 1987, compararam núcleos metálicos fundidos e núcleos de resina composta com pinos intraradiculares, afirmando que em torno de $50 \%$ dos dentes que irão receber uma restauração metálica fundida ou uma coroa de jaqueta necessitam de um núcleo. Para eles os núcleos fundidos apresentam alguns problemas, como necessidade de remoção exagerada de estrutura dental sadia, o alto custo e a retenção insuficiente em alguns casos. Ao final do artigo os autores descrevem uma técnica de confecção de núcleos de preenchimento em molares utilizando resina composta e pinos intra-radiculares. Os autores fizeram um acompanhamento clínico desta técnica durante 13 anos, relatando excelentes resultados. Indicam o uso de pinos intra-radiculares e resinas compostas somente em restaurações unitárias. 
Em 1987, LAMBRECHTS et al. ${ }^{66}$ analisaram várias propriedades das resinas compostas que têm importância clínica e que afetam a durabilidade da restauração final. Verificaram que a contração de polimerização não é um fator primordial em cavidades de pequena extensão, porém em cavidades maiores, a massa de resina a ser polimerizada e as forças de contração prevalecem e podem produzir fendas marginais. Observaram, ainda, que a área cervical é bastante crítica, pois não há quantidade suficiente de esmalte e é importante que a contração seja dirigida para a parede da cavidade, sendo a melhor maneira de inserção do material a utilização de técnicas incrementais. Afirmaram também, que a absorção de água é outra propriedade de impacto sobre a durabilidade clínica de uma restauração, com as resinas de micropartículas apresentando maior absorção. As propriedades mecânicas são afetadas por essa absorção que age como plastificante e agente de corrosão, enfraquecendo a interface partícula/matriz. E concluíram que, em cavidades pequenas, as restaurações de classe I e II com resinas compostas podem ser aceitáveis; porém, em cavidades grandes problemas podem aparecer devido à contração de polimerização, à perda de adesão à dentina, a fraturas e desgaste, não sendo as resinas consideradas substitutas para o amálgama.

LEARY; AQUILINO-ASSWARE ${ }^{67}$, em 1987, avaliaram o comprimento do pino dentro dos limites elásticos da dentina. Utilizaram amostras preparadas com variados tamanhos de diâmetro dos canais e diferentes comprimentos de inserção dos pinos nos canais radiculares. Os resultados mostraram que quando a estrutura dentária interna é removida, o dente fica enfraquecido, que a cimentação de pinos intra-radiculares pré-fabricados recupera apenas parte desta resistência perdida, e que, com pinos cimentados, parece existir alguma transferência de carga.

STOKES ${ }^{120}$, em 1987, realizou uma revisão da literatura a respeito de pinos e seus princípios mecânicos e biológicos. Concluiu que o dente que passa por uma intervenção endodôntica com mínima perda dentinária, não é mais susceptível à fratura do que um dente vitalizado. Entre muitos sistemas 
de pinos avaliados, os pinos cilíndricos cimentados apresentaram o maior índice de sucesso. Pinos cilíndricos rosqueáveis, utilizados em combinação com reconstruções coronárias diretas em resina composta, oferecem uma técnica rápida, mas não devem ser aconselhados enquanto não existirem mais estudos clínicos descritos.

TALEGHANI; MORGAN ${ }^{122}$, em 1987, pesquisaram sobre a utilização de amálgama, resina composta e ionômero de vidro na reconstrução de dentes tratados endodonticamente. Sobre o amálgama, fizeram as seguintes conclusões: a) é o material mais utilizado; b) reduz o tempo de uso e do custo, sem a necessidade de equipamento especial; c) tem boa resistência às forças horizontais e verticais e é um bom suporte para restaurações fundidas; d) a resistência e expansão térmica é duas vezes a do dente e isto é uma desvantagem. Verificaram ainda a utilização do verniz copal para prevenir microinfiltração inicial. Sobre a resina composta anotaram: 1) é de fácil manipulação; 2) é rápido o tempo de polimerização; 3) é baixa a contração de polimerização; 4) dispensa equipamento especial, porém apresenta a desvantagem de ter uma expansão térmica três vezes maior que a do dente, aumentando assim a microinfiltração e permitindo o aparecimento de cárie recorrente. Sobre o ionômero de vidro de presa rápida com partículas de prata (ketac silver), concluíram: a) une-se quimicamente à estrutura dentária; b) libera flúor à estrutura dental adjacente; c) tem fácil inserção; d) serve à preparação imediata do dente; e) apresenta coeficiente de expansão térmica similar ao da estrutura dentária; é, portanto, um material superior ao amálgama e à resina composta.

Afirmando que muita ênfase tem-se dado pela literatura aos pinos préfabricados e pouco têm-se estudado sobre os materiais usados na construção de núcleos, TALEGHANI; LEINFELDER ${ }^{121}$, em 1988, fizeram uma investigação para determinar o potencial de núcleos de ionômero de vidro (reforçado com prata, com e sem pinos intra-radiculares) e de núcleos fundidos comparando-se quanto à melhor resistência à fratura, sob oclusão 
simulada, de pré-molares superiores. Sobre os núcleos foram confeccionadas coroas totais fundidas, sobre as quais foram realizados os testes de resistência em uma máquina Instron. Os resultados mostraram que os núcleos de ionômero de vidro com pinos intra-radiculares ofereceram a mesma resistência à fratura aos dentes do que os núcleos metálicos fundidos e que os núcleos de ionômero sem pinos não foram efetivos em dentes com grande perda coronária.

PLASMANS et al. ${ }^{93}$ publicaram em 1988, um estudo onde avaliavam a resistência à fratura de núcleos de resina composta com e sem pinos intraradiculares. Selecionaram 20 molares inferiores recém extraídos, que tiveram as suas coroas cortadas $2 \mathrm{~mm}$ acima da junção cemento esmalte. Os dentes foram divididos em quatro grupos experimentais e um controle: a) de resina composta auto-polimerizável e pino unimetric; b) de resina composta auto-polimerizável sem pino; c) de resina composta auto-polimerizável na câmara pulpar, resina fotopolimerizável no restante da coroa e pino unimetric; d) de resina composta auto-polimerizável, resina fotopolimerizável no restante da coroa sem pino e o grupo-controle: núcleo metálico fundido. Os dentes, após submetidos à carga constante em 45을 permitiram concluir que os núcleos de resina composta são bastante satisfatórios e que a presença de um pino intra-radicular não trouxe nenhum benefício à resistência do dente, podendo este sofrer uma fratura na porção radicular, não passível de reparo. PLASMANS et al. ${ }^{102}$ afirmaram que um pino metálico pode ser necessário se a câmara pulpar e o remanescente dentário não puderem propiciar retenção e resistência suficiente ao núcleo.

RADKE; BARKORDAR; PODESTA ${ }^{94}$, em 1988, compararam o valor retentivo de três cimentos (fosfato de zinco, ionômero de vidro e policarboxilato) e de um cimento resinoso, utilizados para cimentação de pinos Para-post em dentes com condutos unirradiculares. A análise estatística dos resultados mostrou que o fosfato de zinco e o ionômero de vidro foram os mais retentivos, seguidos pelo cimento de policarboxilato e resina composta. 
Em 1988, SORENSEN ${ }^{108}$ publicou um artigo onde objetivava apresentar diretrizes de procedimentos para restauração de dentes tratados endodonticamente e planejar as bases que levavam em consideração a quantidade de estrutura dentária remanescente e a posição do arco; também considerava os tipos de pilares que os dentes despolpados serviriam. Opina ele que o clínico deve ser flexível, aplicando o tratamento, segundo as necessidades de cada paciente; que cada situação exige técnicas e/ou materiais diferentes. O objetivo principal deverá ser restaurar o dente tratado endodonticamente, restaurando a função com tempo e custos razoáveis para o paciente, além da previsibilidade e longevidade.

ASSIF et al. ${ }^{6}$, em 1989, utilizaram um modelo fotoelástico com 0 intuito de examinar a influência de diferentes tipos de restaurações colocadas após terapia endodôntica, enfatizando a maneira com que as forças aplicadas à superfície oclusal foram distribuídas para as estruturas de apoio dos dentes. Selecionaram pré-molares intactos que, para os testes, foram divididos em 4 grupos: a) dente intacto após obturação do canal; b) dente após tratamento endodôntico coberto com uma coroa total; c) dente com pino e núcleo de resina composta e d) dente com núcleo fundido e coroa total. Os dentes foram montados em um material foto-elástico, após o que foram fotografados no campo de luz polarizada. Ao final, o estudo possibilitou os autores considerarem que, talvez, um pino metálico não atenda todas as necessidades de um dente tratado endodonticamente, pois é feito de um metal rígido com um módulo de elasticidade muito maior do que a estrutura dental e tem o potencial de fraturar a raiz. Para eles o dente deve ser restaurado com um material que possua módulo de elasticidade semelhante ao da dentina, o que pode ser melhor obtido pelas resinas compostas que, também possuem alta resistência ao cisalhamento.

No ano de 1989, BERGMAN et al. ${ }^{14}$ publicaram um estudo sobre dentes tratados endodonticamente, restaurados através de núcleos metálicos fundidos. Foram analisados noventa e seis casos, entre homens e 
mulheres. Destes núcleos fundidos, quarenta e nove receberam coroas individuais e quarenta e sete instalados em dentes suportes para próteses parciais fixas. Os autores concluíram que núcleos metálicos fundidos podem ser recomendados, tanto num caso como no outro, como meio de retenção para restaurações indiretas. As falhas ocorridas no tratamento endodôntico não tiveram nenhuma correlação com o tratamento protético utilizado.

HUNTER; FEIGLIN; WILLIAS ${ }^{56}$, em 1989, estudaram os efeitos do tratamento endodôntico, do preparo do canal para receber pino pré-fabricado e sua cimentação em raízes de incisivos centrais, através da análise fotoelástica. Os resultados demonstraram que a remoção de estrutura dentinária do canal radicular aumenta a concentração de esforços nas paredes e, portando, a tendência à fratura. Pinos com diâmetro mais largos se adaptam melhor ao longo do canal radicular; entretanto, o diâmetro maior em pinos curtos aumenta a concentração de tensão na região apical. Para os autores a cimentação dos pinos intra-radiculares, em dentes com o canal tratado, torna-se desnecessária; mas no caso de canais muito alargados isto reforçaria os dentes.

BARKHORDAR; RADKE; ABBASI ${ }^{11}$, no ano de 1989, tentaram provar a eficiência de um colar metálico na resistência de dentes tratados endodonticamente para fraturas radiculares. Foram selecionados 20 incisivos centrais superiores, sem cáries ou fraturas, e separados em dois grupos de 10 dentes. No Grupo I foram colocados pinos intra-radiculares de 8mm, sem colar metálico; e no Grupo II, pinos intra-radiculares de 8mm e um colar ao redor da porção cervical de $2 \mathrm{~mm}$ de comprimento, com $3^{\circ}$ de angulação de cada lado das paredes dentinárias coronárias, totalizando 6ำ de convergência. A espessura para as paredes de dentina era de $1 \mathrm{~mm}$ pra os dois grupos, e, no segundo grupo, foi confeccionado, por cima da parede, um colar metálico de $2 \mathrm{~mm}$. Os pinos foram fundidos em liga de ouro e cimentados com cimento de fosfato de zinco. As forças oblíquas, durante o teste de compressão, foram aplicadas pela face palatina e à velocidade de $5 \mathrm{~cm} / \mathrm{min}$, em um ângulo de $135^{\circ}$ de inclinação em relação ao plano 
horizontal. Houve uma diferença estatisticamente significativa na localização da fratura entre os dois grupos. Do total, 5 espécimes do Grupo I, sem o colar metálico, fraturaram longitudinalmente; 4 falharam obliquamente, estendendo-se da junção cemento-esmalte para o terço apical; e 1 teve fratura horizontal. A média de carga de falha foi de 49,6kg. No Grupo II, nove espécimes fraturaram, e um foi descartado por fratura da base de resina; 4 tiveram fratura no terço apical, 1 exibiu fratura horizontal e vertical, 2 separados com linha de fratura mais apical na superfície lingual e 1 teve fratura oblíqua. A média de fratura foi de $65,29 \mathrm{~kg}$. Concluíram os pesquisadores que o grupo com colar metálico demonstrou uma média de resistência superior. Isto tem importância, principalmente na utilização do colar metálico como suporte para próteses fixas ou removíveis.

Em 1990, ROBBINS ${ }^{98}$, em revisão de literatura, comentou a importância de alguns parâmetros para nortear a restauração de dentes tratados endodonticamente. Ele parte do princípio de que o cuidado com a máxima preservação da estrutura dentinária, tanto no tratamento endodôntico quanto na confecção do núcleo, é o primeiro passo para o sucesso do tratamento, pois, desta maneira evita-se o enfraquecimento da raiz. O diâmetro do núcleo deve ser o menor possível. O maior comprimento do núcleo aumenta a retenção e a resistência e núcleos rosqueáveis são mais retentivos do que aqueles que apresentam paredes paralelas.

LONEY; KOTOWICS; McDOWELL ${ }^{71}$, em 1990, avaliaram o efeito de abraçamento por uma virola de $1,5 \mathrm{~mm}$ de altura, fazendo a análise de estresse por foto-elasticidade em modelos tridimensionais. O efeito de abraçamento neste estudo foi obtido pelo envolvimento da dentina pelo próprio núcleo metálico. Foi possível notar diferença estatística entre as amostras com e sem virola, em relação à distribuição de tensões. A amostra sem colar metálico evidenciou menor concentração de tensões na região gengival e na parede lingual da raiz, enquanto que, nas demais regiões, não houve diferença estatística entre os grupos. Aplicando-se a força pela face lingual do núcleo, foi registrada uma maior concentração de tensão na 
parede lingual da raiz, junto ao ápice, para ambas amostras. Embora a virola não tenha contribuído para diminuição das tensões sobre a raiz, a distribuição geral das forças foi mais equilibrada do que no grupo sem virola. Os autores da pesquisa entendem que o colar metálico poderia unificar as estruturas remanescentes.

SORENSEN; ENGELMAN ${ }^{109}$, em 1990, pesquisaram o efeito da adaptação de um pino intra-radicular às paredes radiculares, na resistência dos dentes à carga oblíqua. Tomaram 40 incisivos centrais superiores, seccionaram suas porções coronárias, seguindo a junção cemento-esmalte, deixando-os com 15mm de comprimento e os dividiram em quatro grupos, preparando todos com ombro de 90을 permanecendo $1 \mathrm{~mm}$ de dentina na parede cervical. Nos Grupos I, II e III, somente $1 \mathrm{~mm}$ de estrutura axial radicular foi deixado, ao nível do ombro, criando um largo canal com forma afunilada. O tamanho do canal foi igual para todos os grupos e o tamanho coronário do núcleo metálico fundido foi de $7 \mathrm{~mm}$. Um pino intra-radicular de plástico Para-post foi adaptado de acordo com o que se segue, e posteriormente fundido, tornando-se um núcleo metálico fundido. $\mathrm{O}$ Grupo I consistiu de um pino intra-radicular "Para-post", sem se estender dentro do canal; preencheu-se parte do canal com cimento, deixando o pino intra-radicular sem contato direto com as paredes radiculares. No Grupo II, foram usados pinos intra-radiculares com metal intimamente adaptados às paredes do canal, com espessura mínima de cimento. No Grupo III, foram usados pinos intra-radiculares Para-post que preencheram o canal, totalmente adaptados. O processo de ceroplastia das coroas fundidas em metal básico, foi feito diretamente nos dentes. Posteriormente, foram cimentadas com amento de fosfato de zinco. Criou-se um dispositivo nas coroas para permitir uma carga num ângulo de $130^{\circ}$ em relação ao longo eixo do dente. A carga foi executada a uma velocidade de $2,54 \mathrm{~mm}$ por min. Falhas ocorreram devido ao deslocamento da coroa ou do pino intraradicular, à fratura da raiz ou do pino intra-radicular. 
A média de valores de carga até a falha foi de:

$\begin{array}{lll}\text { Grupo I } & 22,4 \mathrm{~kg} & \pm 4,4 \\ \text { Grupo II } & 49,58 \mathrm{~kg} & \pm 10,26 \\ \text { Grupo III } & 29,47 \mathrm{~kg} & \pm 5,89 \\ \text { Grupo IV } & 28,89 \mathrm{~kg} & \pm 9,47\end{array}$

Uma análise do modo de fratura demonstrou que 17 dos 20 dentes nos Grupos II e III falharam, por razões diferentes. Esse índice alto ocorreu em pinos intra-radiculares que se adaptaram intimamente com a configuração radicular. Nas amostras em que somente o Para-post se estendeu dentro do canal (Grupo I e IV), as falhas ocorreram devido à fratura do dente e falha do cimento. Em todas as 6 amostras do Grupo I com falha de cimento ocorreu o entortamento dos pinos intra-radiculares. Vistos de um aspecto proximal, os Grupos II e III tiveram uma incidência de fratura mais alta quando comparados com o Grupo IV. As fraturas do Grupo II e III, em que foram usados pinos intra-radiculares cônicos, envolveram mais estrutura dentária do que os pinos paralelos. Esse estudo questiona a remoção adicional de estrutura dentária para acomodar pinos intra-radiculares de paredes paralelas. O Grupo I, com somente $1 / 3$ dos pinos intra-radiculares em contato íntimo com os remanescentes radiculares, teve uma média de limiar de falha igual àquela do Grupo IV, onde os pinos intra-radiculares eram paralelos, intimamente adaptados às paredes do canal. Uma grande quantidade de cimento circundando os $2 / 3$ incisais dos pinos intraradiculares não afetou o limiar de carga para falha.

Ainda em 1990, SORENSEN; ENGELMAM ${ }^{110}$ estudaram a resistência à fratura de dentes com diferentes tipos de término-gengival para obter 0 efeito de abraçamento através da virola. Definem a virola como uma banda circunferêncial metálica ao redor da margem gengival do preparo do dente, que tem por objetivo melhorar a resistência dental contra as forças de alavanca, contra o efeito de cunha dos pinos cônicos e contra as tensões geradas durante a inserção do pino. Sessenta incisivos centrais tiveram suas 
coroas removidas, permanecendo $15 \mathrm{~mm}$ de comprimento para os Grupos le II, e $17 \mathrm{~mm}$ de comprimento para os Grupos III a VI. Os dentes foram restaurados com núcleos metálicos fundidos e coroas protéticas metálicas. Foram estudados os preparos ombro em $90^{\circ}$, ombro biselado e preparos em $130^{\circ}$, com e sem $1 \mathrm{~mm}$ de remanescente dentinário oclusal à margem do preparo. Os resultados do teste de resistência à compressão demonstraram que, independente do tipo de término, quando havia $1 \mathrm{~mm}$ de estrutura coronária envolvida pelo preparo, a resistência à fratura foi aumentada. Os autores também demonstraram que o remanescente axial do preparo é mais efetivo em aumentar a resistência à fratura do que o bisel isoladamente. Assim, complementam a definição de virola como uma banda metálica que envolve o término do preparo ou a parede axial do preparo, fornecido pela coroa protética e não pelo núcleo.

KING; SETCHELL ${ }^{65}$, em 1990, realizaram um experimento comparando o pino pré-fabricado de fibra de carbono com outros sistemas de pinos e núcleos. Para isso, utilizaram 40 incisivos centrais superiores, seccionados $2 \mathrm{~mm}$ acima do limite amelo-cementário, que receberam 4 diferentes tratamentos de reconstrução intra-coronária e restauração indireta com colar de $1 \mathrm{~mm}$ abraçando o remanescente dental. O primeiro grupo recebeu núcleo metálico fundido; o segundo, pino pré-fabricado metálico e núcleo fundido; o terceiro foi restaurado com pino pré-fabricado metálico e núcleo de compósito; e o último grupo, restaurado com pino de carbono e núcleo de resina. A carga de compressão foi aplicada por uma máquina universal de ensaios, num ângulo de $130^{\circ}$ em relação ao longo eixo do dente, a uma velocidade de $5 \mathrm{~cm} / \mathrm{min}$. Fez-se o registro da carga necessária para causar fratura e o padrão de fratura dos espécimes: resultou uma diferença estatisticamente significativa entre os grupos restaurados com núcleos fundidos e com pinos de carbono e núcleo de resina. Os demais grupos não demonstraram diferença estatística entre si. Todos os espécimes sofreram fratura radicular com deslocamento do pino. Entretanto, o padrão de fratura foi significativamente mais favorável nos dentes restaurados com 
pino de fibra de carbono, se comparado ao grupo restaurado com pino préfabricado metálico.

Em 1990, LYONS 72 , avaliou a máxima força de mordida dental alcançada. Para realização deste trabalho o autor utilizou-se de uma estrutura de aço inoxidável localizada entre os caninos que mensuravam a força de mordida dos pacientes neste local. Os resultados mostraram forças de mordida média na região de caninos em pacientes normais de $22 \mathrm{~kg}$ enquanto pacientes bruxomanos apresentavam média de $26 \mathrm{~kg}$. Ele ainda observou que as forças máximas de mordida encontrada na região de caninos em dois pacientes normais foram de 32 e $35 \mathrm{~kg}$.

PEUTZFELD; ASMUSSEN ${ }^{90}$, em 1990, afirmaram que o risco de fratura de dentes restaurados com pinos intra-radiculares são fartamente descritos na literatura. Afirmam, ainda, que o risco da fratura de um pino depende da sua resistência, marca comercial, metal, forma e diâmetro. A afirmação é o resultado de pesquisas da resistência à flexão e à fadiga de seis diferentes marcas comerciais de pinos intra-radiculares: Flexi-post, Filpost, Radix, Unimetric, Triax e Para-post. Ao final da pesquisa, concluíram que os pinos Radix foram os mais resistentes à flexão e os pinos Unimetric foram os mais resistentes à fadiga.

WEINE; WAX; WENCKUS ${ }^{130}$, em 1991, abordaram a longevidade clínica de núcleos fundidos num período de dez anos. Foram avaliados 138 casos, com o auxílio de radiografias e exames clínicos nos âmbitos periodontais, endodônticos e restauradores. De todos estes casos somente $6,35 \%$ deles falharam. A partir dos resultados obtidos, os autores demonstram uma preferência por pinos fundidos levemente cônicos a pinos pré-fabricados paralelos. Estes últimos removem a estrutura dentinária da porção apical do preparo e se adaptam perfeitamente ao formato do canal; mas apesar dos melhores resultados de adaptação, os pinos pré-fabricados não têm o mesmo desempenho clinicamente. 
YAMAN; THORSTEINSSON ${ }^{131}$, em 1992, analisaram, em modelos de resina fotoelástica, a influência de diferentes complexos formados por materiais de preenchimento e pinos intra-radiculares, na distribuição de estresse. Os pinos intra-radiculares testados foram os de forma cilíndrica e serrilhados, avaliados em três situações: 1) na instalação; 2) com carga vertical e 3) com carga angulada em 26․․ No Grupo I, fez-se uso de pinos intra-radiculares Para-post; no Grupo II, a resina composta (concise) foi usada como núcleo de preenchimento, aliada aos pinos intra-radiculares "Para-post"; no Grupo III empregou-se amálgama (Tyntin) como núcleo de preenchimento, mais pinos intra-radiculares Para-post; no Grupo IV foi utilizado núcleo metálico fundido, confeccionado a partir de um pino Para-post plástico, próprio para fundição; todos os pinos intra radiculares Para-post tinham diâmetro de 1,6mm. Construiu-se uma matriz em resina própria para modelos de fotoelasticidade, com um furo no centro, onde todos os espécimes foram cimentados com fosfato de zinco. Uma matriz foi posicionada na parte coronária dos pinos intra-radiculares para a confecção do núcleo de preenchimento. A parte do pino que estava inserida no bloco de resina acrílica media $9 \mathrm{~mm}$, e a parte externa media $5 \mathrm{~mm}$, totalizando $14 \mathrm{~mm}$. Fez-se a análise num polariscópio circular, onde foram identificadas franjas nos terços cervical, médio e apical dos pinos. Os resultados mostraram que, na inserção, os núcleos metálicos fundidos quase não criaram estresse. Os pinos intra-radiculares pré-fabricados evidenciaram estresse no terço cervical e apical, sobressaindo-se o grupo das resinas. Durante a inserção, não se constatou nenhuma diferença estatisticamente significativa entre os grupos; mas o grupo da resina criou mais estresse na região apical. Relativamente à carga vertical, o Grupo I não mostrou estresse, enquanto todos os outros demonstraram diferenças significativas. O grupo da resina mostrou estresse similar ao do amálgama de prata e menor que os núcleos metálicos fundidos na região cervical. Todos demonstraram estresse igual no terço médio; na região apical, o de menor estresse foi o grupo dos núcleos metálicos fundidos; o grupo sem preenchimento, no entanto, acusou maior estresse, e o da resina e 
amálgama de prata em média intensidade; mas todos demonstraram estresse.

Com carga de 26ํㅜ, houve acúmulo de estresse em um só lado, resultando em uma distribuição assimétrica de estresse. Na região cervical, o estresse estava concentrado abaixo dos núcleos de preenchimento, com o grupo dos núcleos metálicos fundidos sendo significativamente mais estressante que os outros grupos.

Concluindo, os pinos intra-radiculares pré-fabricados, aliados a um núcleo de preenchimento de resina, provavelmente geram estresses nos dentes tratados endodonticamente durante sua inserção e quando submetidos a forças verticais.

Utilizando um modelo fotoelástico bi-dimensional ROLF; PARKER; PELLEU ${ }^{100}$, em 1992, avaliaram o estresse gerado por cinco modelos de pinos intra-radiculares pré-fabricados. Sendo: 1) Para-post, pino rosqueado com sulco de escape para cimento não retido na dentina; 2) Beta-post, pino com roscas axiais com sulco de escape para cimento não retido na dentina; 3) Kurer Crown Anchor, pino com roscas em espirais sem sulco de escape e retenção em dentina através de roscas; 4) Flexi-post, pino com roscas transversais com sulco de escape e auto-rosqueável e 5) Radix Anker, pino com roscas em espirais com sulco de escape para cimento e autorosqueável. Todos os modelos acusaram níveis variáveis de estresse: nos sistemas Flexi-post e Radix Anker observaram-se quantidades mínimas de esforço; porém o pino Radix Anker apresentou a metade da retenção em relação ao Flexi-post e ao Kurer Crown Anchor; nos núcleos cimentados Beta-post e Para-post, verificourse a menor tensão entre todos os sistemas. Os sistemas que promoveram a melhor combinação de alta retenção e baixa tensão, foram o Radix Anker e o Flexi-post.

No ano de 1992, SEDGLEY; MESSER ${ }^{102}$ analisaram as propriedades biomecânicas de vinte e três dentes tratados endodonticamente e seus pares vitais contra-laterais. No estudo, foram testadas as seguintes 
variáveis: resistência à tração, módulo de elasticidade, dureza e resistência à fratura. A análise estatística, utilizando teste "t" pareado, não revelou nenhuma diferença estatisticamente significante entre os dois grupos. Os pesquisadores, baseados nas similaridades existentes em propriedades biomecânicas entre dentes vitais e não vitais, afirmam que o tratamento endodôntico não torna o dente mais frágil. E provam que fatores como perda de estrutura dental por cárie, acesso endodôntico, instrumentação endodôntica, traumas e preparos cavitários contribuem muito mais para a fragilidade do dente.

CAILLETEAU; RIEGER; AKIN ${ }^{17}$, em 1992, pretendendo determinar os efeitos da distribuição das tensões de um pino metálico cilíndrico nas paredes do canal radicular, utilizaram o método de elementos finitos. Para isto, empregaram quatro modelos bidimensionais de incisivos centrais superiores, incluindo ligamento periodontal e osso alveolar. O modelo um representava um dente intacto; o modelo dois um dente desvitalizado e restaurado com amálgama de prata; o modelo três, um dente restaurado com uma coroa total; e o modelo quatro, um dente restaurado com pino e coroa total. Todos os materiais possuíam as mesmas propriedades (isotrópicos) e todos fram submetidos à força de $1 \mathrm{~N}$ na superfície lingual. Depois de feitos os testes, os autores, concluíram que o pino não distribui as tensões uniformemente ao longo da raiz; e que, quando estes apresentavam paredes paralelas, a força de compressão gerava alta concentração de tensões junto ao seu término apical.

Numa revisão de literatura, GUTMANN ${ }^{46}$, em 1992, considerou que as propriedades dos dentes despolpados e os conseqüentes procedimentos restauradores poderiam ser responsáveis ou não pelo sucesso do tratamento. Enfatizou o uso de um mapeamento completo da anatomia e da biologia da dentina e da raiz que deve passar por restauração, pois procedimentos endodônticos e restauradores alteram estes tecidos duros. A dentina de dentes despolpados se modifica em sua estrutura interna, o que diminui a resistência ao estresse e à flexibilidade e, devido à perda de 
umidade e estrutura do dente, técnicas de preenchimento da raiz requerem procedimentos restauradores especiais, relacionados à anatomia radicular $e$ osso suporte. A preservação da estrutura dentária apresenta-se como o fator de maior importância para a resistência à fratura do dente tratado endodonticamente. A utilização de pinos intra-radiculares só é indicada no caso de retenção e estabilização do núcleo coronário e não para reforçar raízes fragilizadas.

No trabalho de HUANG; SCHILDER; NATHANSON ${ }^{55}$, publicado em 1992, foram analisadas espécimes de dentina, entre dentes vitais e dentes tratados endodonticamente, com o objetivo de determinar se há diferença significativa entre as propriedades mecânicas da dentina, entre ambos. As propriedades mecânicas foram avaliadas depois das amostras serem submetidas a diferentes situações, como testes de compressão, tração e impacto. Os resultados deste estudo permitiram concluir que a desidratação após o tratamento endodôntico, não enfraquece a dentina, porque não houve diferença estatisticamente significante na resistência à compressão e tração dos dentes despolpados contrapostos aos dentes vitais.

SORNKUL; STANNARD ${ }^{114}$, propuseram avaliar a resistência à fratura de raízes de pré-molares inferiores com e sem tratamento endodôntico. Ele observou que as raízes não tratadas mostraram as mais altas resistências às fraturas e concluiu que os fatores importantes para se evitar fraturas devem ser a quantidade de estrutura dentária remanescente, a resistência do pino, e o sistema adesivo entre o material de preenchimento e a dentina.

BEX et al. ${ }^{15}$, em 1992, compararam a resistência à força de cisalhamento de dentes anteriores superiores tratados endodonticamente e reforçados com núcleo metálico fundido ou núcleos de resina composta (Adaptic) e adesivo dentinário (Oxalato férrico, NTG-GMA e PMDM, sistema desenvolvido por Bowen). Os dentes foram montados em uma máquina de testes, em ângulo de $90^{\circ}$. Através dos resultados concluíram que apesar dos núcleos metálicos fundidos serem cerca de três vezes mais resistentes que os núcleos de resina composta, a falha destes só ocorre sob grande força, 
podendo ser, pois, bastante satisfatórios. Os autores também concluíram que os núcleos de resina composta geralmente têm falha coesiva; não ocorrendo fratura radicular; o que não acontece com os núcleos metálicos fundidos que, geralmente ocasionam fratura radicular. Por outro lado, os núcleos de resina composta, segundo os pesquisadores, quando falham, são passíveis de sofrerem uma nova restauração o que nem sempre ocorre com os núcleos metálicos fundidos.

MORGANO; MILOT ${ }^{86}$, em 1993, analisando resultados clínicos de pinos metálicos fundidos, observaram que o insucesso do tratamento pode ocorrer por falha de retenção devido ao comprimento, folga dentro do conduto, contaminação do cimento com saliva, resíduos de lubrificantes ou cimento temporário e, também, por fratura na raiz. Recomendam, então, a utilização dos núcleos metálicos nos dentes anteriores e posteriores, que perderam estrutura dental coronária; e aconselham a utilização de pinos fundidos, os mais longos possíveis, respeitando-se quatro a cinco milímetros de obturação endodôntica. Ainda com relação à fratura, atribuem-na ao desenho do pino, a paredes paralelas, à exagerada pressão hidráulica durante a cimentação, a bolhas durante a fundição. E concluem que a incidência destes fatores diminui quando uma atenção especial é dada à adaptação dos pinos dentro do conduto.

LINDHE $^{70}$, no ano de 1993, utilizou-se de resina composta associada à ancoragem com pinos intra-radiculares pré-fabricados para a construção de núcleo de preenchimento em tratamentos endodônticos. A resina composta the parece o material mais indicado para a reconstrução de raízes muito fragilizadas. Chamando a atenção para a dificuldade de fotopolimerização em áreas de difícil acesso, o que faria com que estas partes ficassem com resistência inferior, recomenda, a necessidade do uso de resina composta autopolimerizável.

COHEN et al. ${ }^{28}$, em 1993, analisaram as propriedades de retenção dos sistemas de pinos pré-fabricados rosqueados Access-post e World-post. Onze grupos de dez dentes foram comparados. Os pinos foram cimentados 
com cimento fosfato de zinco e com cimento resinoso reforçado com titânio Flexi-flow; como controle, o pino Para-post cimentado com fosfato de zinco. Depois de combinar os elementos e fazer análises, conclui-se que o grupo com pinos Access-post cimentado com Flexi-flow em dentina com superfície irregular, foi estatisticamente, mais retentivo que os cimentados com fosfato de zinco.

Em 1993, ASSIF et al. ${ }^{4}$ analisaram se o formato do pino em dentes tratados endodonticamente teria correlação com fraturas que eventualmente ocorrem. Num estudo in vitro, foram utilizados pré-molares recém-extraídos e divididos em quatro grupos. O primeiro grupo recebeu pinos metálicos fundidos convencionais; o segundo grupo, pinos cilíndricos Para-post; no terceiro foram inseridos pinos cilíndricos com término apical cônico; e no quarto grupo, pinos de reconstrução com cimento de ionômero de vidro Ketac-fill. Foram cimentadas sobre as reconstruções, coroas protéticas sobre um término cervical de $2 \mathrm{~mm}$ de dentina. Para testar a resistência à fratura, as amostras receberam cargas crescentes de compressão com angulação de $30^{\circ}$, até haver falha na restauração. Os resultados demonstraram que o desenho do pino não causa fratura; que outros fatores podem contribuir para a variação dos valores de resistência, como o grau de calcificação do dente, a distância do limite amelo-cementário até a força aplicada, a direção da força, as variações das dimensões e a estrutura dos canais. Os autores ainda concluem que, se não houver necessidade de retenção, os pinos intra-radiculares podem ser dispensados até nos casos de reconstrução protética.

Com o objetivo de determinar a forma ideal de restaurar um dente tratado endodonticamente, ROBBINS et al. ${ }^{99}$, em 1993, selecionaram 60 caninos que sofreram um corte perpendicular na junção cemento-esmalte e foram montados em um cilindro de PVC, em resina acrílica com $2 \mathrm{~mm}$ de dente externamente. Formaram-se 6 grupos, de 10 dentes cada, sendo: a) pinos intra-radiculares cilíndricos cimentados com ionômero de vidro 9mm dentro do canal e $4 \mathrm{~mm}$ para fora e pino intra-dentinário com núcleo de 
amálgama; b) pino intra-radicular cônico, pino intradentinário e núcleo de amálgama como no grupo "a"; c) apenas guta percha no canal radicular; d) guta percha no canal e resina composta na câmara pulpar; e) apenas pino cônico cimentado no canal da mesma forma que nos grupos "a" e "b" e grupo "e" f) dentes sem nenhum tratamento (controle). Todos os dentes receberam uma coroa total fundida em ouro sendo posteriormente montado em um ângulo de 45ㅜ; após foram sujeitados a uma força de compressão em uma máquina de ensaios universal. A conclusão foi de que não houve diferença estatística na resistência à fratura dos dentes restaurados com pinos cilíndricos ou cônicos. Não houve diferença estatística entre os grupos mas os pesquisadores alertam que a remoção de estrutura dental sadia enfraquece o dente mesmo que o reforcemos de alguma forma.

Para comparar a retenção e estabilidade dos sistemas de pinos intraradiculares pré-fabricados Flexi-post, Para-post e Brasseler, KEYF; SAHIN ${ }^{64}$, em 1994, selecionaram 42 raízes de incisivos superiores tratadas endodonticamente. Cada pino foi cimentado no canal com cimento de fosfato de zinco e o teste dividido em duas fases: na primeira, uma força tensional foi aplicada ao bngo do eixo de cada dente até o deslocamento do pinonúcleo. Nesta fase observourse que, quanto à resistência a tração, em pinos de diâmetros médio e grande, a diferença foi bem mais significante do que em pinos de diâmetros menores. Pinos Flexi-post (médios) mostraram-se duas vezes mais retentivos que os outros. Na segunda fase foi aplicada uma carga tangencial de compressão, num ângulo de $130^{\circ}$, e, novamente, pinos Flexi-post mostraram-se mais estáveis que os demais.

Em 1994, LEVARTOVSKY et al. ${ }^{68}$ compararam a resistência mecânica de três materiais empregados em núcleos de preenchimento: resina composta (Flúor-Core), ionômero de vidro fotopolimerizável (Variglass VLC) e um ionômero de vidro reforçado com prata (Miracle Mix). Os corpos de prova foram obtidos de acordo com a especificação n.27 da A.D.A, sendo que as propriedades avaliadas foram: resistência à compressão, tração e cisalhamento. Após 24 horas de conservação em 100\% de umidade a 37으, 
as amostras foram testadas em uma máquina de testes universal Instron. Os resultados obtidos levaram à conclusão de que a resina composta FlúorCore apresentou os melhores resultados, seguida pelo Variglass e, por último, com resultados bem inferiores, o cimento de ionômero de vidro Miracle Mix; aliás os autores salientaram que este último material não apresenta propriedades satisfatórias que justifiquem o seu emprego para núcleo de preenchimento.

ASSIF; GORFIL ${ }^{5}$, em 1994, indicaram alguns procedimentos biomecânicos para dentes que foram tratados endodonticamente. Questionam sobre o aumento da resistência destes dentes por causa da presença de pinos intra-radiculares e sobre a fragilidade de dentes despolpados, em relação aos vitais, por perda de umidade da dentina. Afirmam que a quantidade de estrutura dental remanescente é que proporciona a resistência dental e que quanto menor o remanescente dentário menor a resistência. Sugerem que as experiências feitas para os sistemas de pinos são questionáveis porque não refletem condições clínicas específicas, porque a porção coronária do pino fica recoberta com coroa total e que, como a coroa altera a distribuição de forças para as raízes, seria esta coroa quem garantiria a proteção da raiz contra fratura. Sendo assim, o tipo de pino tem pouca influência na resistência à fratura. Afirmam, ainda, que aumentar o diâmetro e o comprimento do pino, na tentativa de melhorar a retenção dele, compromete o prognóstico de um dente restaurado. Como resultado dos seus estudos, concluem que pinos intra-radiculares devem ser usados somente quando a estrutura dental remanescente não permitir outra alternativa restauradora e, ainda, que se deve preservar ao máximo a estrutura dentinária.

COHEN et al. $^{31}$, em 1994, estudaram a resistência à fratura de três diferentes materiais de preenchimento, suportados por três diferentes marcas comerciais de pinos intra-radiculares. Selecionaram dentes uni-radiculares, recém-extraídos, que tiveram seus canais radiculares obturados antes de receberem três diferentes pinos intra-radiculares: 
Flexi-post, Vlock e Para-post. Após a cimentação dos pinos, reconstruiram-se as coroas dentárias com resina composta (ti-Core), amálgama (TYNin) e ionômero de vidro (Ketac silver). Os dentes foram montados em cilindros de resina acrílica antes de serem colocados em um ângulo de $45^{\circ}$ para os testes de resistência em uma máquina de ensaios. Ao final do estudo, ficou claro que os pinos Flexi-post e Vlock forneceram maior resistência ao dente, vindo por último os pinos Para-post. Em relação aos materiais de preenchimento, as resinas compostas foram as mais resistentes, superando o amálgama, apontado como material frágil, que precisa de volume, sendo, portanto, enfraquecido pela presença de pinos. Os núcleos de Ketac-silver foram os menos resistentes, o que segundo os pesquisadores é devido a sua baixa resistência à compressão.

MANNING et al. ${ }^{76}$, em 1995, revisaram conceitos teóricos que devem ser considerados para a reconstrução de dentes tratados endodonticamente, com pinos e núcleos. Como os dentes despolpados são mais friáveis que dentes vitais - por causa da perda de umidade e de prováveis alterações na sua morfologia - deve-se considerar esta fragilidade com relação à aplicação de cargas, que aumentam o risco de fratura. Outra característica é o risco relacionado à anatomia radicular para a acomodação de um pino, que, se não observada, pode predispor raízes finas às perfurações e fraturas. Os autores salientaram que a resistência do remanescente também se deve à quantidade de estrutura dentinária preservada; afirmam que pinos intra-radiculares não contribuem para o aumento da resistência à fratura e, ainda, que estes só devem ser utilizados em caso de retenção para o núcleo e coroa protética, onde ocorre grande perda de estrutura dental coronária.

Ainda em 1995, MANNING et al. ${ }^{77}$ reavaliaram alguns pinos e núcleos de dentes tratados endodonticamente, considerando que a colocação de um núcleo não reforçará um dente que tenha estrutura dentária sadia. Núcleos metálicos fundidos tem menor risco de falhas, mas exigem um tratamento mais demorado quanto aos procedimentos clínicos e laboratoriais. Núcleos de resina composta apresentam boa resistência, mas é um material que tem 
coeficiente de expansão térmica duas vezes maior que o do dente, favorecendo microinfiltrações. Os núcleos de cimento de ionômero de vidro oferecem maior preocupação, pelo risco de microfraturas, pois, são menos resistentes à tração.

TORBJÖRNER; KARKSSON; ODMAN ${ }^{124}$, em 1995, publicaram um estudo de avaliação feita em 638 pacientes, ao longo de dez anos, procurando analisar 0 comportamento de 788 dentes tratados endodonticamente. Verificaram que 456 dentes receberam núcleos metálicos fundidos e 332 receberam pinos pré-fabricados. Avaliaram o percentual de falhas e o padrão de fratura. Depois de um período de quatro a cinco anos foram detectadas falhas de $15 \%$ para núcleos metálicos fundidos e de $8 \%$ para pinos pré-fabricados, sendo que a retenção foi a falha mais comum em ambos os grupos. Analisando fraturas com a indicação de extração, registrourse um percentual de $5 \%$ para núcleos metálicos fundidos e $2 \%$ para pinos pré-fabricados. No total geral, setenta e dois dentes falharam, mas, a causas pelas quais ocorreram estas falhas não foram estudadas.

Comparando a resistência à força torcional em sete diferentes sistemas de pinos pré-fabricados metálicos, COHEN et al. ${ }^{30}$, em 1995, estudaram o comportamento destes pinos em 150 raízes de incisivos centrais e laterais. Segundo seus depoimentos, a força torcional foi escolhida por ser o melhor método para comparar a estabilidade dos pinos pré-fabricados. Os pinos metálicos avaliados nesta experiência foram: Flexipost; Flexi-flange; Para-post; Vlock-post; Access-post; Dentatus; World-post. Todos cimentados com cimento de fosfato de zinco e cimento resinoso Flexiflow. As amostras foram divididas em onze grupos e submetidas à forças torcionais no sentido horário. Os pinos Flexi-post e Flexi-flage, cimentados com fosfato de zinco e cimento resinoso, demonstraram maior resistência estatística contra as forças de torção.

MENTINK et al. ${ }^{81}$, em 1995, identificaram como um dos problemas na fabricação de núcleo de preenchimento de resina a incorporação de bolhas. 
Isso, segundo os autores, diminui rapidamente as propriedades desejáveis das resinas compostas. Assim, realizaram um estudo para investigar o efeito de duas diferentes técnicas de manipulação na incorporação de porosidades, nos núcleos de preenchimento, em uma situação. Usaram dentes molares humanos, com tratamento endodôntico, e duas resinas compostas, sendo uma autopolimerizável (Clearfil - Kuraray) e a outra fotopolimerizável (Photo core - Kuraray). Numa das técnicas utilizourse a inserção com instrumento manual, e, na outra, a seringa. Das amostras, 20 dentes receberam pinos intra-radiculares e outros 20 não receberam nenhum pino intra-radicular. As amostras foram seccionadas para análise.Os resultados mostraram que uma porcentagem mínima de bolhas superficiais foi registrada na série de amostras que usou a resina composta autopolimerizável com pino intra-radicular na técnica da seringa. $O$ porcentual mais alto de bolhas foi encontrado na resina autopolimerizável inserida pela técnica manual. A técnica de inserção manual de resina composta fotopolimerizável foi significativamente inferior, ou seja, exibiu mais bolhas do que a técnica de inserção com seringa. A colocação de pinos intra-radiculares não afetou as diferentes técnicas. A inserção de resina composta, nesse estudo, pela técnica manual, causou incorporação de bolhas em $95 \%$ dos corpos, independentemente do tipo de resina.

Em 1996, CHRISTENSEN ${ }^{25}$ procurou analisar a necessidade da colocação de pinos intra-radiculares em dentes tratados endodonticamente e, se, realmente, fortalecem os dentes quando cimentados no canal. Ele afirma que a principal função dos pinos é promover a retenção para a restauração protética em dentes onde o tecido coronário foi perdido. Nos dentes tratados endodonticamente com perda mínima de estrutura dental, recomenda a restauração com materiais ionoméricos, resinosos ou com amálgama de prata, sem a instalação de pinos no interior do canal, quando a perda de estrutura coronária é pequena. A restauração protética com pinos e núcleos só deve ser utilizada em casos extremos, como, em dentes que perderam mais da metade da coroa dental. Nesta situação pinos préfabricados e núcleos de preenchimento tornam-se os mais indicados. 
VERLUIS; TANTBIROJN; DOUGLAS ${ }^{129}$ realizaram estudo, também em 1996, no qual referem ser amplamente aceito que a contração volumétrica e a solidificação durante o processo de polimerização das resinas compostas, em combinação com a adesão às estruturas dentárias duras, resultam em transferência de estresse e deformação das paredes da cavidade de dentes restaurados. Afirmam que essa deformação diminui o tamanho das cavidades durante o processo de preenchimento, tendo esse fato uma influência profunda no assunto, discutido nesse trabalho, de que uma técnica de preenchimento incremental reduz o efeito da contração de polimerização sobre 0 dente. Os autores analisaram numericamente 0 desenvolvimento dos campos de estresse para diferentes técnicas incrementais; os resultados mostraram que, em uma restauração com adesão adequada ao dente, a técnica incremental aumentou a deformação do dente restaurado, levando à formação de uma estrutura dente/resina com níveis mais altos de estresse. Concluíram que a técnica incremental pode ser necessária devido a outras razões, mas não devido aos efeitos da contração de polimerização.

CARVALHO et al. $^{20}$, em 1996, afirmaram que a inserção de resinas compostas adesivas nos preparos cavitários leva à competição entre as forças de contração de polimerização e a força de adesão à estrutura dental. Entendem que o grau de desenvolvimento do estresse pode ser controlado em parte, pelo desenho da cavidade (fator $\mathrm{C}$ ), pelo uso de bases, pelo tamanho, pela forma e posição dos incrementos de resina composta colocados na cavidade e, ainda, se a resina é foto ou quimicamente ativada. A compensação ou alívio do estresse pode ser conseguido, segundo eles, mantendo o fator $\mathrm{C}$ o mais baixo possível, utilizando resinas quimicamente ativadas, bases cavitárias com baixo módulo e, com o passar do tempo, pela sorção de água. Assim, concluíram que o entendimento desses princípios permite aos clínicos obter maior controle, melhorando a qualidade das restaurações adesivas. 
Em 1996, ABDALLA; ALHAYDAINY ${ }^{1}$ avaliaram o desempenho clínico de três resinas compostas em restaurações classe I de pré-molares, classificando a resina Z-100 como de melhor desempenho, quando analisados a integridade marginal, o manchamento marginal, a descoloração e a forma anatômica. Na sua avaliação, atribuem o superior desempenho ao alto conteúdo de carga incorporada à matriz, possível devido ao tamanho e à forma das suas partículas, totalizando $66 \%$ do seu volume. Este maior conteúdo de carga inorgânica corresponde à máxima resistência à compressão, à dureza superficial e à resistência ao desgaste. Além disso, seu modo de Young é semelhante ao da dentina, tornando o dente restaurado resistente às cargas oclusais.

Para comparar a distribuição do estresse fotoelástico em quatro tipos de pinos endodônticos, COHEN et al. $^{32}$, em 1996, realizaram um estudo aplicando cargas verticais e oblíquas, num ângulo de $26^{\circ}$, sobre dentes restaurados com pinos rosqueáveis. Os sistemas avaliados foram 0 Flexi-post, Flexi-flage, Para-post e Access-post. Os resultados mostraram que mesmo sem nenhum tipo de cargas os pinos provocam um estresse pequeno, que quando submetidos à carga vertical os pinos foram considerados excelentes. Os pinos Para-post apresentaram respostas assimétricas em todos os testes, porem com uma maior concentração de estresse na região apical.

Avaliando o comportamento de limite de carga de pinos Flexi-post, Flexi-flange, Para-post, Access-post e C-post, restaurados com amálgama de prata-Tyntin, resina composta reforçada com titânio (Ti-Core) e ionômero reforçado por prata (Ketac-Silver e ionômero modificado - G.C Miracle Mix) COHEN et $\mathrm{al}^{29}$. 1996, concluíram que a maior resistência aconteceu nas restaurações com amálgama/Para-post. O pior resultado ocorreu com 0 grupo Ketac Silver/Para-post e a grande maioria das falhas (79\%) no núcleo de preenchimento. Em $21 \%$ dos casos houve fratura do dente, e em nenhuma situação se evidenciaram falhas nos pinos. 
MORGANO ${ }^{84}$, em 1996, analisando métodos de restauração em dentes despolpados, afirmou que pinos intra-radiculares não devem ser utilizados para reforçar a estrutura remanescente; sua indicação deve estar restrita a casos em que há estrutura inadequada para reter uma restauração coronária.

HOLMES; DIAZ-ARNOLD; LEARY54, em 1996, em trabalho de Modelo de Elemento Finito levantaram os valores para módulo de elasticidade das diversas estruturas dentais e alguns em gpa. Assim: dentina $=18,6$; cemento $=18,6$; ligamento periodontal $=0,0689$; osso cortical $=13,7$; osso trabecular $=1,37$; gengiva $=0,003$; ouro fundido $=96,6$; porcelana $=69$; cimento de fosfato de zinco $=22,4$. Os autores simularam a inserção de um núcleo metálico fundido em um dente cujo remanescente dentinário permitia a confecção de uma férula de $2 \mathrm{~mm}$ na parte coronal. O estudo demonstrou que: o pico compressivo e o estresse por tração ocorreram no terço coronário da dentina; o pico de estresse de cisalhamento ocorreu adjacente ao pino intra-radicular no terço médio da raiz; a magnitude do estresse de cisalhamento foi influenciada pelo tamanho do pino intra-radicular. Com o aumento do pino intra-radicular, ocorria diminuição do estresse de cisalhamento no terço médio da raiz.

COHEN et al. $^{33}$, em 1997, compararam a resistência à fratura de 3 materiais utilizados para reconstrução coronária (resina composta Ti-Core, amálgama de prata Tytin, e cimento de ionômero de vidro híbrido Advance), sobre pino pré-fabricado rosqueado com fenda Flexi-Flange e com pinos dentinários sem núcleo intra-radicular. Foram usados 60 dentes unirradiculares, recém-extraídos, divididos em 6 grupos com 10 amostras, que receberam forças de compressão num ângulo de 45, com velocidade de $0,63 \mathrm{~mm} / \mathrm{minuto}$. Obteve-se uma diferença estatisticamente significante entre os materiais restauradores, mas não relacionada aos pinos. 0 compósito Ti-Core teve um limiar médio de resistência à fratura maior do que o amálgama Tyntin e o ionômero de vidro Advance, sendo que estes não tiveram diferenças estatisticamente significantes entre si. Também não 
foram verificadas diferenças estatísticas entre a resina Ti-Core, suportada por pino ou não. Embora os pinos não tivessem sido cobertos com coroas totais neste estudo, os autores consideram que os resultados obtidos foram relevantes, porque a resistência das restaurações foram testadas no pior tipo de situação.

SMITH; SCHURMAN ${ }^{106}$, em 1997, elaboraram um guia de procedimentos para auxiliar na restauração de dentes tratados endodonticamente, baseando-se na quantidade de estrutura coronária remanescente, com o objetivo de otimizar a função e a estética do dente a ser tratado. No caso de um dente possuir um mínimo de comprometimento da porção coronária e estética necessárias, uma restauração direta com resina composta ou cimento de ionômero de vidro reforçado com prata é indicada. Quando for o caso de se utilizar pinos intra-radiculares estes devem ser de acordo com a configuração do canal radicular. Os autores reconhecem que uma decisão correta, em certos casos, é um processo complicado, pois, existem poucos resultados clínicos avaliados em longo prazo até o momento.

SIDOLI; KING; SETCHELL ${ }^{103}$, em 1997, compararam a performance e a resistência à fratura de pinos de fibra de carbono (C-post), em relação aos existentes pinos metálicos e núcleos em compósito. Foram selecionados 40 incisivos centrais e caninos superiores, divididos em 4 grupos com os seguintes tratamentos: dentes restaurados com C-post e núcleo de resina; dentes restaurados com pino metálico e núcleo em resinas; dentes restaurados com núcleo metálico fundido; e dentes íntegros, onde foi realizado tratamento endodôntico. Todas as amostras foram recobertas com restaurações protéticas, cimentadas com fosfato de zinco. A carga de compressão foi aplicada num ângulo de $50^{\circ}$ em relação ao longo eixo do dente, à velocidade de $5 \mathrm{~cm} / \mathrm{min}$. Os dentes somente com acesso endodôntico mostraram resistência à fratura superior aos demais grupos; depois deles os dentes restaurados com núcleos metálicos fundidos e pinos pré-fabricados, que não mostraram diferença estatística entre si. 
Resultados inferiores foram demonstrados quando se utilizou o pino de fibra de carbono. O padrão de fratura foi examinado macroscopicamente e microscopicamente, sendo que os melhores resultados foram para os pinos de carbono, e em seguida para os pré-fabricados, que se mostraram compatíveis com a reconstrução dental, após fratura.

Em 1997, BAHARAV et al. ${ }^{8}$ analisaram o efeito do tempo de irradição nas propriedades de tensão de dureza e resistência das resinas compostas. Utilizaram materiais que continham grande quantidade de partículas de carga, e que eram muito friáveis. Assim, os escolhidos foram a Herculite XRV (Kerr), Brilliant (Coltene) e P-50 (3M). Um molde cilíndrico de politetrafluoretileno com $2 \mathrm{~mm}$ de espessura, com uma extensão de $4 \mathrm{~mm}$, foi preenchido com resina composta, tampado com fitas de poliéster nas extremidades. A ponta da unidade de luz ativadora foi colocada em cima da fita de poliéster. O material era irradiado por 20, 40, 80 ou 120 segundos. Num total de 120 espécimes, dez espécimes foram preparados para cada combinação de material e tempo. Antes do teste, os corpos de prova foram armazenados em $100 \%$ de umidade, a $37^{\circ} \mathrm{C}$, por 24 horas. Os corpos de prova foram submetidos a tensão diametral com uma máquina de teste universal a uma velocidade de $0,5 \mathrm{~cm}$ por min. Obteve-se como resultado que: os materiais não diferiram significativamente entre si quanto à resistência à tensão diametral, mas diferiram quanto à dureza; houve diferença significativa, considerando-se o tempo de irradiação por 20 segundos, mas a partir daí, os outros tempos (40, 80 ou 120 segundos) não alteraram a dureza significativamente.

SMITH; SCHUMAN; WASSON ${ }^{107}$, em 1998, estudando a relação pino/conduto/cimento, concluíram que os núcleos metálicos fundidos são indicados nos casos de condutos elípticos ou de maior diâmetro e os pinos pré-fabricados são compatíveis em dentes com canais circulares e/ou de menor diâmetro. Relativamente aos materiais para preenchimento, a resina composta mostra uma adequada resistência mecânica, capacidade de polimerização e rápida cura; mas, apresenta como inconveniente a 
tendência à microinfiltração. O amálgama é fácil de manipular, apresenta alta resistência à compressão e baixa característica de microinfiltração; sua desvantagem maior é a demora e a pouca capacidade de adesão. $O$ ionômero de vidro, apesar de apresentar adesividade à estrutura dentária, liberação de flúor e baixo coeficiente de expansão térmica, não é um material resistente.

Em 1998, McLEAN ${ }^{75}$, publicou um estudo que apresentava uma técnica direta para a restauração de dentes tratados endodonticamente. Ele considerava que a única função de um pino intra-radicular é promover a retenção para a reconstrução coronária e, que esta, ainda pode ser considerada ativa ou passiva. Os núcleos ativos são aqueles que oferecem uma retenção adicional que promove um engajamento mecânico na dentina. Os núcleos passivos são os paralelos ou os cônicos, pré-fabricados e fundidos, sendo que os paralelos oferecem maior retenção. McLEAN ${ }^{89}$ entende que, se for realmente necessária a utilização de um pino, que este seja um de menor diâmetro, paralelo, de retenção passiva, com comprimento igual ou maior que a coroa clínica, cimentado com fosfato de zinco ou cimento híbrido de resina/ionômero de vidro, deixando um vedamento apical de $4 \mathrm{~mm}$.

Para analisar a resistência à fratura de raízes restauradas com duas diferentes técnicas, FRAGA et al. ${ }^{43}$, em 1998, realizaram um estudo in vitro de 27 raízes de dentes unirradiculares recém extraídos, com diâmetro cervical semelhante e posteriormente divididas em dois grupos. O primeiro grupo, com 14 amostras, recebeu núcleos metálicos fundidos. O segundo grupo, com as 13 amostras restantes, recebeu pinos pré-fabricados e núcleo de resina composta. Nos dois grupos o comprimento do pino intra-radicular foi de $8 \mathrm{~mm}$ e a cimentação feita com cimento de fosfato de zinco. Mediante a aplicação de uma carga num ângulo de 45ํㅡ em relação ao longo eixo do dente, o primeiro grupo apresentou maior resistência à fratura. Mas, apesar deste resultado, o estudo ainda aponta para os núcleos pré-fabricados reconstruídos com resina composta como o sistema mais recomendável, 
porque, todas as falhas ocorreram na estrutura de resina e isto possibilitou a proteção da dentina radicular.

ZALKIND; HOCHMAN ${ }^{132}$, em 1998, a respeito dos núcleos fundidos, ensinaram que eles são indicados quando não há estrutura dentária remanescente suficiente para utilizar os núcleos pré-fabricados. Entretanto, quando a raiz permite e existe quantidade suficiente de dentina, os pinos pré-fabricados podem ser empregados. Além da fácil manipulação e rápido endurecimento, os pinos possibilitam a preparação em uma só visita e tem baixo custo. Ressaltaram, também, a necessidade de resultados esteticamente satisfatórios, já que houve o aumento da utilização da coroa de porcelana pura. O pino de cerâmica de zircônia oferece uma base estética para uma coroa totalmente cerâmica.

MCLEAN $^{74}$, em 1998, apresentou critérios para que o clínico fosse capaz de identificar dentes tratados endodonticamente, que pudessem ser restaurados com um alto nível de previsibilidade, fornecendo uma visão baseada em evidências científicas. Segundo ele, para que um dente tratado endodonticamente não necessite de um pino intra-radicular, o dente deve ter 2,0 $\mathrm{mm}$ de férula dentinária efetiva para reter a prótese; e, ainda, que dentes tratados endodonticamente devem ser evitados como pilares suportados por encaixes de precisão, extensão distal ou cant laver.

Estudando a resistência à fratura de 2 tipos de restaurações (dentes restaurados com pinos de carbono pré-fabricados e núcleo de compósito e dentes restaurados com núcleos fundidos) MARTINEZ-INSUA et al. ${ }^{79}$, em 1998, mostraram que o limiar de fratura média foi de 103,7kg para o Grupo I e 207,7kg para Grupo II. No Grupo II, entretanto, a fratura quase sempre afetou o próprio dente, enquanto no Grupo I, o conjunto pino/núcleo quase sempre falhou primeiro. Os autores concluíram que o limiar de fratura significativamente mais alto foi registrado para o grupo de pino e núcleo fundido. Dentes restaurados com pinos fundidos tipicamente mostraram fratura do dente, embora em cargas que raramente ocorrem clinicamente. Concluíram ainda que pinos e núcleos usados para a restauração de dentes 
despolpados devem ter resistência suficiente, mas não superior à do pino; que a falha do pino seja anterior à da estrutura dentária remanescente em resposta ao estresse mecânico. Neste estudo, o limiar de falha de pinos de fibra de carbono foi significativamente mais baixo do que o limiar para pinos fundidos. Pinos fundidos comumente resultaram em fratura dentária.

A resistência à fadiga, de três tipos de núcleos sem a utilização de coroa protética, foi avaliada por REAGAN et al. ${ }^{97}$, em 1999. No primeiro grupo, utilizaram-se dois pinos pré-fabricados com núcleo de amálgama; no segundo grupo, os mesmos pinos pré-fabricados com núcleo de resina composta; e no terceiro, núcleos metálicos fundidos como controle. Depois de submetidos a testes de fadiga até a ocorrência de fratura, o grupo restaurado com núcleo de compósito apresentou valores superiores aos dos outros grupos; isto se atribui ao fato da resina composta ter baixo módulo de elasticidade, que permite uma melhor absorção dos impactos durante o teste de fadiga mecânica.

SIRIMAI; RIIS; MORGANO ${ }^{105}$, em 1999, avaliaram a resistência à fratura vertical de 60 incisivos centrais tratados endodonticamente e restaurados com seis diferentes métodos de pinos e núcleos protéticos. Os sistemas escolhidos foram: núcleos metálicos fundidos cimentados com fosfato de zinco; pinos pré-fabricados metálicos cimentados passivamente com fosfato de zinco e núcleo em resina; fibras de polietileno fixadas com cimento resinoso e envoltas por núcleo em resina; pino pré-fabricado metálico passivo e núcleo confeccionado com fitas de polietileno e resina; pinos pré-fabricados metálicos passivos fixados com cimento resinoso e núcleo em resina. Utilizourse uma velocidade de $0,5 \mathrm{~mm} / \mathrm{min}$, num ângulo de 130 para a realização do teste de resistência a compressão. Concluiu-se que a adição de fibras de polietileno a um núcleo pré-fabricado resulta em menor quantidade de fraturas no sentido vertical, se comparado a núcleos metálicos fundidos. Mas os núcleos metálicos fundidos são os que apresentaram maior resistência à fratura, entre os núcleos estudados. 
STOCKTON ${ }^{119}$, em 1999, publicou uma revisão de literatura, estabelecendo alguns critérios que podem ser seguidos para a restauração de dentes tratados endodonticamente, para otimizar a retenção e diminuir o risco de fratura. Ele sugere que o primeiro passo seja o diagnóstico radiográfico detalhado da raiz para o sucesso do tratamento. A estrutura dental deve ser conservada ao máximo, levando em consideração que canais amplos são mais propensos à fratura se comparados a ocorrências tais provocadas pelos diversos modelos de pinos. Com relação aos pinos, itens como comprimento, diâmetro, desenho do núcleo devem ser escolhidos conforme a necessidade do paciente. O autor enfatiza que a técnica de cimentação é que deve ser levada em consideração, porque os cimentos geralmente apresentam o mesmo padrão de comportamento. Aconselha que cada situação seja analisada de acordo com a necessidade de cada caso.

ISIDOR; BRONDUM; RAVNHOLT ${ }^{58}$, 1999, procuraram avaliar o efeito do comprimento dos pinos pré-fabricados e do comprimento da férula na resistência à fadiga, em 90 raízes de dentes bovinos restaurados com coroas metálicas. Os pinos pré-fabricados foram cimentados ao canal radicular com cimento de fosfato de zinco e construíram núcleos de preenchimento sobre pinos metálicos com comprimento de 5, 7,5 e 10mm. E férulas de amanhos $0,1,25$ e 2,5mm. A retenção e a estabilidade do pino intra-radicular/núcleo de preenchimento e coroas foram testadas em testes de fadiga, com freqüência de uma carga por segundo e intensidade de $400 \mathrm{~N}$, simulando o movimento de mastigação. Finalizados os testes, as seguintes observações foram feitas: o aumento do tamanho da férula para dentes com coroa e pinos intra-radiculares/núcleos de preenchimento reforçou à resistência da amostra; já o tamanho do pino não apresenta grande influência nesta variável.

Uma ampla revisão de literatura realizada por MORGANO; BRACKETT ${ }^{85}$, no ano de 1999, teve como objetivo analisar os melhores métodos de retenção para dentes tratados endodonticamente. Entre os 
fatores mais destacados para o sucesso destas restaurações foram os cimentos utilizados. Afirmaram esses pesquisadores que o fosfato de zinco é ainda o cimento de utilização de uma grande maioria de profissionais, tendo como desvantagem a grande solubilidade que sofre diante dos fluídos bucais. Cimentos de policarboxilato e ionômero de vidro tem sido relatados como fracos quanto a sua união à dentina. Cimentos resinosos, com seus adesivos, são insolúveis no meio bucal e são bem retentivos. Cuidados especiais devem ser previstos em condutos contaminados com eugenol que pode alterar sua presa. O cimento resinoso deve ser colocado somente no pino e nunca no conduto, pois a falta de oxigenação pode levar à uma presa prematura do cimento. Os autores sustentam que o espaço intra-radicular para colocação do pino deve oferecer resistência à rotação deste. Destacam como desvantagem dos núcleos metálicos fundidos o fato de necessitarem duas visitas ao consultório. Materiais restauradores devem suportar o estresse induzido por forças mastigatórias. Outros fatores, tais como a quantidade de tecido dental residual, tempo de consulta clínica, facilidade de manipulação, devem ser considerados, quando estamos selecionando o sistema de pinos intra-radiculares/núcleo de preenchimento. Considerações econômicas também podem afetar a escolha de uma técnica. Os autores verificaram, ainda, que o percentual de uso de pinos pré-fabricados tem se tornado muito popular entre os dentistas dos Estados Unidos. Constataram que $40 \%$ dos dentistas generalistas usam pinos pré-fabricados, na maioria das vezes, e que os mais usados são os pinos pré-fabricados serrilhados; e, mais que o uso de pinos pré-fabricados, aliado a uma reconstrução de núcleo de preenchimento é, geralmente, tido como um método restaurador de escolha para molares desvitalizados com perda excessiva de substância dental.

GATEAU; SABEK; DAILEY4 ${ }^{44}$ em 1999, fizeram um estudo comparativo da resistência mecânica de pinos pré-fabricados: a) os de titânio restaurados com amálgama de prata; b) os de ionômero de vidro reforçado com prata e resina composta. Os dentes foram preparados para coroas totais fundidas e estas ḋmentadas com cimento de ionômero de 
vidro. Em cada grupo selecionaram 20 espécimes para o experimento e 5 ficaram como controle. Foi aplicada uma força de $400 \mathrm{~N}$, que corresponde à carga mastigatória. E os dentes foram seccionados, para serem observados microscopicamente. Os testes demonstraram que houve fratura, iniciando-se nos pinos intra-radiculares, fratura dentro do material, variação de separação ao longo dos pinos intra-radiculares, microinfiltração cervical e presença de porosidade. Nas amostras com amálgama de prata não havia defeitos; nas amostras de resina composta os defeitos foram observados entre o núcleo de preenchimento e os pinos; e nas amostras com ionômero de vidro ocorreram fraturas entre o ionômero de vidro e o pino intra-radicular e também no corpo do ionômero. Concluiurse que os núcleos construídos com amálgama são os mais resistentes.

$\mathrm{CHO}$ et al. $^{24}$ testaram, em 1999, a resistência à compressão e a resistência à tração diametral de seis diferentes materiais preconizados no mercado como núcleos de preenchimento. Utilizaram espécimes cilíndricos com $6 \mathrm{~mm}$ de altura e $4 \mathrm{~mm}$ de diâmetro dos materiais a serem testados.As resinas Compostas (Prodigy-250,3 MPa) e (Herculite- $\pm 220 \mathrm{MPa}$ ) foram as que apresentaram melhores resultados, havendo diferenças estatisticamente significante entre elas. O amálgama de prata, com alto teor de Cobre (Valiant PHD), teve valor inferior a $200 \mathrm{MPa}$. Embora houvesse diferença estatisticamente significante entre esse material e as duas resinas, não houve diferença entre este último e a resina autopolimerizável testada (Core Paste), que chegou a 200MPa. Os valores de resistência à tração diametral mostraram que a Prodigy obteve 55,1 MPa, similar ao amálgama de prata Valiant PHD e perto da Herculite, que chegou próximo de $51 \mathrm{MPa}$. Não houve diferença estatisticamente significante entre esses três materiais; mas houve entre eles e a resina autopolimerizável Core Paste, sendo, os primeiros, superiores. Os outros materiais testados foram a resina modificada por titânio (TI-Core), os cimentos de ionômero de vidro (Ketac Silver) e um poliuretano (Structure). 
COHEN et al. $^{34}$, em 2000, comparou a retenção de dois tipos de materiais de preenchimento (ticor, resina reforçada com titânio e lonômero de vidro Silver-GC Miracle Mix.) sobre 3 tipos de pinos pré-fabricados, 2 de aço inox (Flexi-Post, AccessPost) e um de carbono (Cerapost). Os materiais foram levados à máquina 810 MTS e os testes de retenção foram realizados. Observaram diferença estatística entre os pinos e materiais utilizados, apresentando maior retenção os de aço inox e melhor resultados para o TiCore.

Em 2000, CRUZ; MAI; SHELLARD ${ }^{35}$, demonstraram que a importância de uma eficiente polimerização das resinas compostas no menor tempo possível impulsiona o desenvolvimento de equipamentos mais eficientes. Neste estudo, avaliaram o grau de polimerização de 2 fotopolimerizadores, Optilux 500 e Optilux 501 (alta potência), por meio de testes de dureza das resinas Herculite XRV, TPH, Prodigy, Z-250, Tetric Ceram, Vitalescense e Point 4, cada uma delas em 2 diferentes cores, exceto a Point 4. Amostras cilíndricas com $10 \mathrm{~mm}$ de diâmetro x $2 \mathrm{~mm}$ de espessura foram confeccionadas, polimerizadas por 40 segundos com Optilux 500 ou por 10 segundos com Optlux 501, e armazenadas a 37ํㅡ com $100 \%$ de umidade relativa durante 24 horas. A dureza foi determinada na superfície de cada amostra, com um durômetro. Os resultados mostraram que, entre as resinas estudadas, a de maior valor foi a resina Z-250, sendo que a cor não teve influência nos resultados. Os dois fotopolimerizadores testados apresentaram desempenho semelhante, mostrando que o novo modelo, Optilux 501, é eficiente, reduzindo o tempo de exposição.

PILO ${ }^{91}$, em 2000, propôs-se a avaliar a espessura dentinária residual de pré-molares inferiores, depois do preparo do espaço para o pino com brocas Gates-glidden e Para-post. O autor comenta que dentes tratados endodonticamente comumente requerem uso de pinos de estabilização corono-radicular e que a principal razão para este pino é reter o núcleo que substitui a porção coronal ausente e fornecer retenção para uma restauração definitiva. Comenta ainda, que as pesquisas têm confirmado que pinos não 
reforçam dentes, mas possuem o potencial de enfraquecê-los. Enfatiza que a técnica mais segura para a remoção de guta percha tem sido o uso de um instrumento aquecido, porém a mais comum e mais rápida é a dos instrumentos rotatórios. Este procedimento é tradicionalmente realizado através de brocas de gates glidden, Brocas de Peeso, Instrumentos gPX, ou com brocas fornecidas em vários kits de pinos. Brocas de gates glidden não possuem ponta ativa e são consideradas mais seguras e previsíveis para preparo do conduto. $\mathrm{O}$ autor utilizou 12 pré-molares inferiores unirradiculares, os quais foram incluídos em resina acrílica autopolimerizável até a junção cemento/esmalte (CEJ). Três secções horizontais foram feitas, 1,3 e $5 \mathrm{~mm}$ em direção ao ápice; após o preparo do conduto com limas número 40 e posteriormente com brocas gattes gliden, eixos mesial e distal e vestíbulo-lingual foram cuidadosamente marcados e a dentina residual foi medida para cada fatia. Concluiurse que a espessura dentinária média de $5 \mathrm{~mm}$ abaixo da CEJ nas direções mesial e distal após o preparo do espaço do pino aproximou ao mínimo aceito de $1 \mathrm{~mm}$, afirmando que um preparo conservador deve ser feito pois este é o principal fator que determina 0 prognóstico de dentes tratados endodonticamente e restaurados proteticamente.

Uma revisão de literatura sobre fatores que afetam a fratura de dentes reconstruídos com pinos e núcleos foi realizada por FERNANDES; DESSA ${ }^{42}$, em 2001. Analisando os artigos estudados, o autor chegou à conclusão de que os fatores principais são: comprimento, diâmetro e material do pino, os materiais dos núcleos de preenchimento, a adaptabilidade do pino, desenho e a cimento utilizado. A literatura mostra, que para conseguir uma longevidade do dente restaurado é necessário: que haja preservação de estrutura dentária, que não devem ser utilizados pinos com o intuito de reforçar dentes, que se deve fazer uma cuidadosa avaliação das forças funcionais e para-funcionais. Além disso, FERNANDES; DESSA ${ }^{48}$ ensinaram que a escolha do material de preenchimento e que suas características de distribuição de estresse sejam bem avaliadas pelo 
clínico. Os núcleos de amálgama e resinas compostas têm sido observados como eficientes na distribuição do estresse.

HENRY et al. ${ }^{49}$, em 2001, procurou verificar o efeito combinado e individual do tratamento endodôntico e a restauração com coroas venners de incisivos centrais superiores. Para isto foram selecionados 40 dentes, divididos em 4 grupos de 10. O Grupo I foi composto por dentes intactos, o Grupo II por dentes tratados endodonticamente, o Grupo III por dentes restaurados por coroas venner e o Grupo IV por dentes tratados endodonticamente e restaurados com coroas venners. Todos os espécimes foram levados à máquina de ensaios universal para os testes de compressão, realizados a uma angulação de 30․ As médias encontradas foram $415 \mathrm{~N}, 370 \mathrm{~N}, 420 \mathrm{~N}$ e $448 \mathrm{~N}$ para os Grupos I, II, III, IV respectivamente. Analisando os resultados o autor chegou à conclusão que os dentes tratados endodonticamente são capazes de suportar a mesma magnitude de forças oblíquas que um dente intacto; e que o tratamento endodôntico, a restauração com coroas venners e a combinação entre eles não foi capaz de afetar o modo de falhas dos incisivos centrais superiores.

$\mathrm{CHAIN}^{22}$, em 2001, mostra que a contração de polimerização nunca foi superada de forma relevante, sendo um problema da odontologia restauradora. Relatou que a rigidez ou módulo de elasticidade de um material é tão importante quanto sua deformação e que não há relação entre a contração volumétrica e a tensão de contração, mas sim uma relação significante entre esta última e o módulo de elasticidade. Assim, afirmou que quanto mais carga tiver o compósito, menor é a sua contração volumétrica, mas maior ambém a sua rigidez, causando maior tensão de contração. Concluiu que nem grande quantidade de carga e nem alto módulo de elasticidade são propriedades favoráveis das resinas compostas, sendo a contração volumétrica um número inútil para predizer o comportamento clínico de uma resina composta e que, para contornar esse problema, o clínico deve utilizar técnicas de fotopolimerização que prolonguem o ponto gel das resinas, tais como a técnica estratificada e a do pulso tardio. 
SORENSEN et al. ${ }^{113}$ em 2001 , estudou critérios de seleção para pinos e núcleos na restauração de dentes tratados endodonticamente avaliando as propriedades físicas dos materiais de preenchimento, as forças de inclinação de pinos pré-fabricados, e a retenção de materiais de preenchimento para pinos de zircônia. $\mathrm{O}$ autor concluiu que, quando houver menos da metade do remanescente dentário coronal um pino ou núcleo deve ser indicado. Mostrou, ainda, diferenças estatisticamente significativas entre os materiais dos núcleos de preenchimentos testados em relação a sua força flexural, tendo a resina composta apresentado os melhores resultados. Além disso mostrou que o pino pré-fabricado de aço inoxidável foi significantemente mais resistente que os outros sistemas de pinos.

Em 2001, ECKERBOM; MAGNUSSON ${ }^{39}$, entrevistaram 892 cirurgiões dentistas clínicos gerais e 150 protesistas suecos, investigando quais suas opiniões atuais sobre como restaurar um dente tratado endodonticamente. Para isto um questionário contendo 31 questões foram distribuídos entre eles. Vinte e nove porcento dos dentistas entrevistados e $17 \%$ dos protesistas são de opinião que pinos intra-radiculares reforçam dentes tratados endodonticamente. A grande maioria dos profissionais suecos utiliza núcleos metálicos fundidos, apesar do grande sucesso dos pinos pré-fabricados.

RAYGOT ${ }^{96}$, em 2001, analisou a resistência e modo de fratura de incisivos tratados endodonticamente, restaurados com núcleo metálico fundido, pinos de aço-inoxidável e pinos de carbono. Foram selecionados 30 incisivos humanos, os quais foram divididos em 3 grupos de 10 cada, um para cada tipo de pino. Após a cimentação dos pinos e das coroas, todos os espécimes foram levados à máquina de ensaios universal para realização dos testes de compressão a $130^{\circ}$. Os resultados não encontraram diferença estatisticamente significativa entre os grupos estudados. O autor, ainda, observou que 70 a $80 \%$ de todos os dentes apresentavam fratura acima do nível ósseo possibilitando assim o preparo. 
HEYDECKE; PETTERS ${ }^{52}$, em 2002, realizaram uma revisão de literatura para comparar a performance clínica e in vitro de núcleos fundidos e núcleos de preenchimento com pinos pré-fabricados em dentes unirradiculares. A comparação das cargas de fratura nos estudos in vitro não revelaram diferenças estatisticamente significativas entre as duas modalidades de tratamento. A taxa de sucesso para núcleos fundidos, em dois estudos, teve média de 87,5\%; em um terceiro estudo alcançou $86,4 \%$ para núcleos de preenchimento após 72 meses.

CÂNDIDO $^{18}$, em 2002, realizou um trabalho determinando a microdureza de 3 resinas compostas (Solidex, Artglass, Filtek Z-250). A análise dos resultados permitiu concluir que a resina composta Filtek Z-250 apresentou maiores valores médios de microdureza superficial. O autor comentou que a resina Z-250 apresenta maior aplicabilidade clínica devido à sua maior facilidade de manuseio, ao menor tempo de trabalho e indicação para aplicação em restaurações diretas e indiretas.

CARVALHO JÚNIOR ${ }^{21}$, em 2002, avaliou a dureza superficial, a contração de polimerização e a rugosidade de 29 resinas compostas. Concluiu que todas as resinas estudadas aumentaram de dureza após 168 horas em relação ao valor da medição inicial, e que a resina Z-250 apresentou o quinto menor valor em relação à dureza inicial e terceiro maior valor em relação à dureza final, ficando em terceiro lugar em relação ao desempenho global.

Em 2002, AKKAYAN², analisou o efeito de 4 sistemas de pinos intraradiculares sobre a resistência à fratura de dentes tratados endodonticamente. Selecionados 40 caninos superiores, foram divididos em 4 grupos de 10, restaurados com pinos de titânio (Grupo I), fibras de quartzo (Grupo II), fibra de vidro (Grupo III) e zircônia (Grupo IV). Após a cimentação dos pinos e das coroas, os dentes foram encaminhados à máquina de ensaios universal para testes de compressão a 130 ao longo eixo do dente. Os resultados encontrados foram $66,95 \mathrm{~kg}, 91,20 \mathrm{~kg}, 75,90 \mathrm{~kg}, 76,91 \mathrm{~kg}$ para os Grupos I a IV, respectivamente. O Grupo II apresentou resistências 
significativamente maior que os outros três grupos. Os Grupos III e IV foram estatisticamente similares. O autor observou, ainda, que as fraturas ocasionadas no Grupo II e III eram totalmente reparáveis enquanto fraturas irreparáveis ocorreram nos Grupos I e IV. 
3 PROPOSIÇÃO 


\section{PROPOSIÇÃO}

A proposta do presente trabalho é avaliar a resistência à fratura de dentes tratados endodonticamente, restaurados com pinos intra-radiculares pré-fabricados, e núcleos de preenchimento em resina composta analisando:

- a influência da presença ou não de remanescente dentário coronal;

- o comportamento das resinas: Z-250 (fotopolimerizável) e Enforce Core (polimerização dual), na reconstrução da porção coronária. 
4 MATERIAL E MÉTODOS 


\section{MATERIAL E MÉTODOS}

\subsection{MATERIAL}

Para a realização deste trabalho foram utilizados os materiais descritos na Tabela 1.

Tabela 1 - Materiais de consumo utilizados

\begin{tabular}{|c|c|c|}
\hline MATERIAL & MARCA COMERCIAL & FABRICANTE \\
\hline Pino pré-fabricado & Unimetric & $\begin{array}{c}\text { Dentsply Ind e Com. Petrópolis - } \\
\text { R.J-Brasil - Lote } 186317\end{array}$ \\
\hline Sistema Adesivo & Single bond adhesive & $\begin{array}{l}3 \text { M Dental Products División } \\
\text { St.Paul, Minisota-USA - Lote } 1105\end{array}$ \\
\hline Sistema Adesivo & Prime \& Bond 2.1 & $\begin{array}{c}\text { Dentsply Ind e Com. Petrópolis - } \\
\text { R.J.-Brasil - Lote } 1208\end{array}$ \\
\hline Agente Cimentante & Fosfato de Zinco & $\begin{array}{l}\text { SS White Artigos Dentários } \\
\text { Ltda S. Cristóvão - R.J.-Brasil } \\
\text { - Pó-lote 00E - Líq.Lote 00P }\end{array}$ \\
\hline $\begin{array}{l}\text { Resina Acrílica auto } \\
\text { polimerizável }\end{array}$ & Jet & Simplex do Brasil \\
\hline $\begin{array}{l}\text { Resina Composta } \\
\text { Fotopolimerizável }\end{array}$ & Z-250 & $\begin{array}{l}3 \text { M Dental Products División } \\
\text { St.Paul, Minisota-USA - Lote } 27032\end{array}$ \\
\hline $\begin{array}{c}\text { Resina Composta de } \\
\text { Cura Dual }\end{array}$ & Enforce Core & $\begin{array}{l}\text { Dentsply Ind e Com. } \\
\text { Petrópolis - R.J.-Brasil - Lote } 558\end{array}$ \\
\hline
\end{tabular}

Os demais instrumentos e dispositivos utilizados encontram-se disponíveis nos laboratórios de pesquisas do Departamento de Prótese da FOB-USP. 


\subsection{MÉTODO}

Os fatores em estudo foram: variação do remanescente dentário em duas alturas, $3 \mathrm{~mm}$ e sem remanescente dental coronal e resinas compostas utilizadas no preenchimento coronário. Todos os preparos receberam término gengival em ombro, e retenção intra-radicular com pino pré-fabricado de titânio cônico passivo associado a núcleo de preenchimento em resina composta de cura dual (Enforce Core) e fotopolimerizável (Z-250). A variável de resposta foi a resistência à fratura, verificada em unidades experimentais compostas por raízes de caninos superiores humanos tratados endodonticamente. Para cada condição em teste foram utilizadas 20 raízes, perfazendo um total de 40 amostras.

\subsubsection{SeleçÃo dos Dentes, Limpeza e ARMAZENAMENTo}

Os dentes foram armazenados e mantidos em condições úmidas (solução isotônica de cloreto de sódio a $0,9 \%$ e cristais de timol) durante todo o experimento. Antes de sua utilização, os dentes foram limpos com curetas periodontais (Duflex/SS White, Juiz de Fora, MG) e jatos de bicarbonato de sódio (Profident/DabiAtlante AS, Ribeirão Preto-SP).

Para realização deste estudo foram utilizados 40 caninos superiores, padronizados quanto à anatomia e dimensões, com comprimento radicular variando entre 16 e $19 \mathrm{~mm}$.

\subsubsection{TRATAMENTO ENDODÔNTICO}

As aberturas das câmaras coronárias para terapia endodôntica foram realizadas, inicialmente, com uma ponta diamantada esférica 
1012 (KG Sorensen) em alta rotação; e a forma de contorno com uma ponta diamantada tronco-cônica, 2082 (KG Sorensen), de ponta inativa, e com a broca de Batt (Dyna-GS Brasil Com. Imp. Ltda) em baixa rotação, procedeur se à forma de conveniência.

Após a abertura coronária, realizourse a odontometria com limas tipo K-file (Maillefer) de $31 \mathrm{~mm}$, a $1 \mathrm{~mm}$ do ápice. Logo após a instrumentação empregou-se a técnica Escalonada Regressiva Programada ou Telescópica, cuja lima-memória foi a de n.35 pela International Standartization Organization (ISO) e o recuo programado até a lima n.45. A irrigação foi feita em cada intervalo de lima, utilizando-se Hipoclorito de Sódio a 1\% (Solução de Milton) e a secagem com pontas de papel absorvente (Tanari, Tamariman Industrial LTDA, Macaçaruru-AM).

A técnica de obturação foi a condensação lateral vertical, utilizando-se cones deguta-percha (Tanari, Tamariman Industrial LTDA, Macaçaruru-AM) n.35 ISO e cimento Endomethasone Ivory (Septodont-França).

\subsubsection{DistRIBUIÇÃO dOS GRUPOS}

Após a seleção dos 40 dentes, procedeu-se uma escolha aleatória para formação dos grupos, a serem submetidos a diferentes tipos de procedimentos a saber:

GRUPO I - Dentes com 3mm de remanescente coronal, restaurados com pinos pré-fabricados e resina de cura dual Enforce Core. 
GRUPO II - Dentes com 3mm de remanescente coronal, restaurados com pinos pré-fabricados e resina composta fotopolimerizável Z-250.

GRUPO III - Dentes sem remanescente coronal, restaurados com pinos préfabricados e resina de cura dual Enforce Core.

GRUPO IV - Dentes sem remanescente coronal, restaurados com pinos préfabricados e resina composta fotopolimerizável Z-250.

\subsubsection{Preparo dos Dentes}

\subsubsection{Grupos I e II com Remanescente CoRonaL}

Visando a padronização dos preparos, os dentes foram demarcados, com grafite, na junção amelocementária; e a partir desta delimitados os 3mm de remanescente coronal e realizado o seccionamento com ajuda um disco de carburundum (Dentorium Expot. Ltda). Após este procedimento, os remanescentes dentários foram preparados, através de sulcos de orientação confeccionados com uma ponta diamantada n.1051 (KG Sorensen). Esses sulcos foram unidos para determinar o término cervical em ombro reto. (Figura 1). 

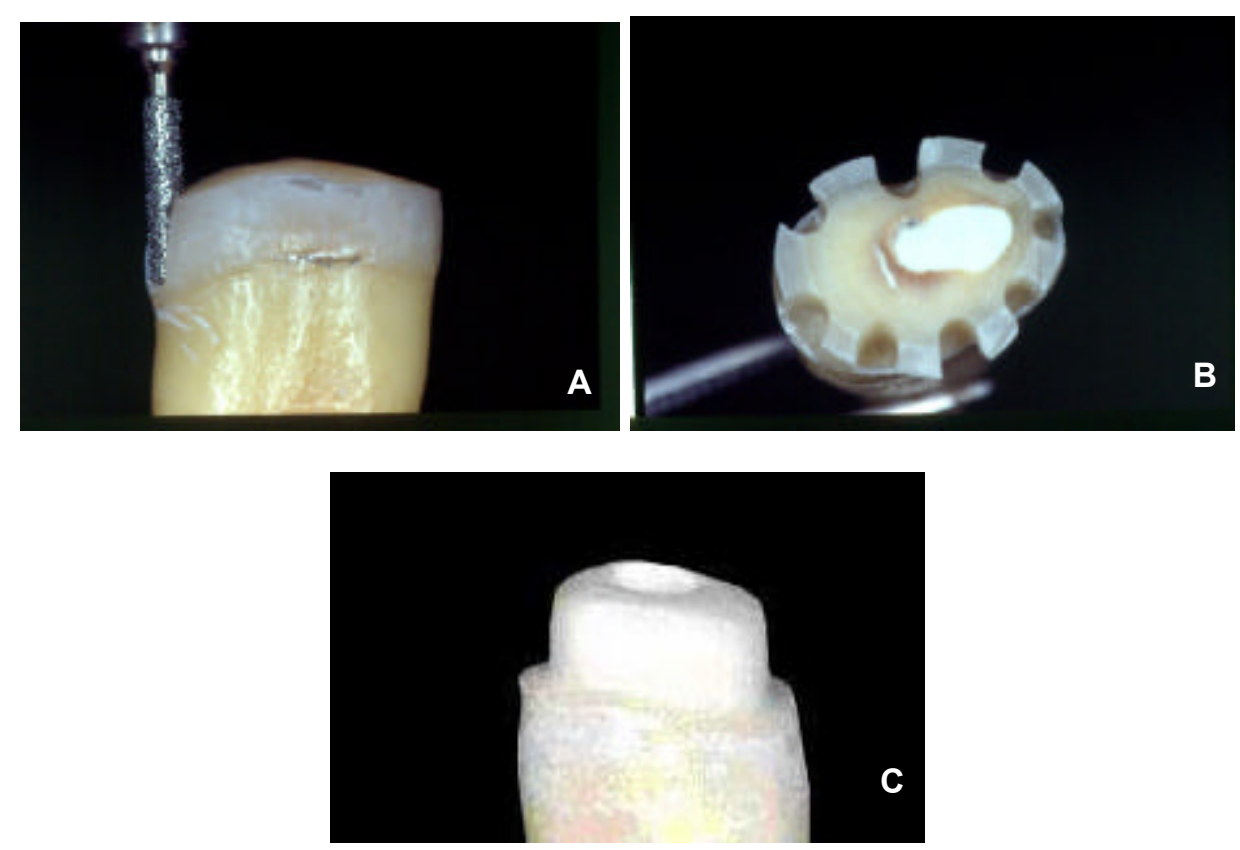

FIGURA 1 - Preparo dos dentes com remanescente coronal
A) ponta diamantada n.1051 posicionada padronizando a profundidade do preparo;
B) sulcos de orientação confeccionados
C) preparo concluído.

\subsubsection{Grupos III e IV SEM RemANESCENTE CoRONAL}

Os dentes foram, inicialmente, demarcados com um grafite no limite amelo-cementário, e, posteriormente, as coroas seccionadas com a utilização de um disco de carburundun (Figura 2). 


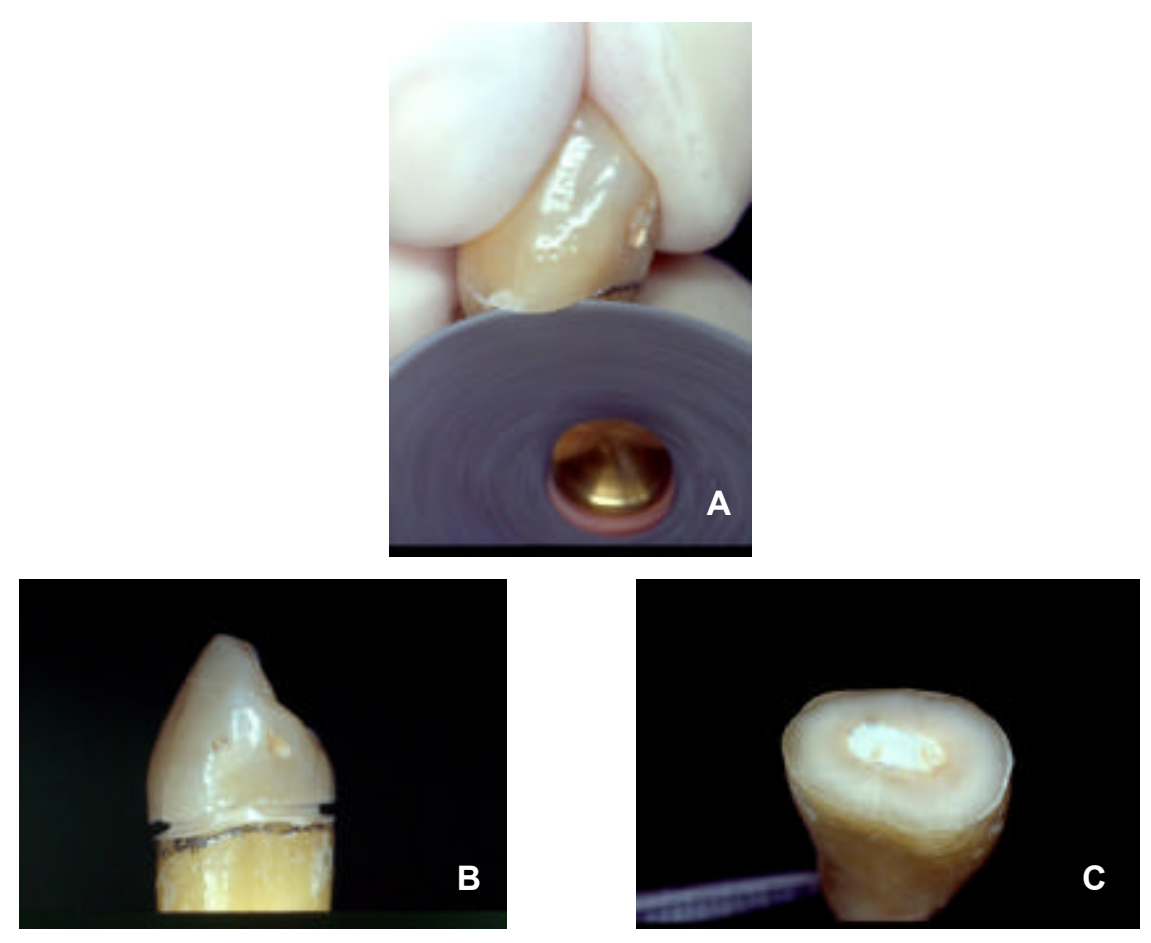

FIGURA 2 - Preparo dos dentes sem remanescente coronal - etapa de seccionamento
A) disco de carburundun posicionado no limite amelo-cementário;
B) canaleta de referência para o seccionamento;
C) seccionamento concluído.

\subsection{Preparo dos Condutos}

Para remoção da guta percha foram utilizadas pontas Rhein (Duflex) com cursores graduados em $11 \mathrm{~mm}$, mantendo-se, no mínimo, 5mm de material obturador remanescente no ápice.

Selecionou-se o pino número $308 \mathrm{~s}$, de $15 \mathrm{~mm}$ do sistema de ancoragem intra-radicular Unimetric (Dentsply Ind e Com. Petrópolis-RJ. Brasil), cuja broca correspondente foi inserida no canal radicular, procurando-se padronizar o diâmetro do conduto e inclinação das paredes. Todos os pinos apresentaram-se com $4 \mathrm{~mm}$ de seu comprimento acima da junção cemento/esmalte. 


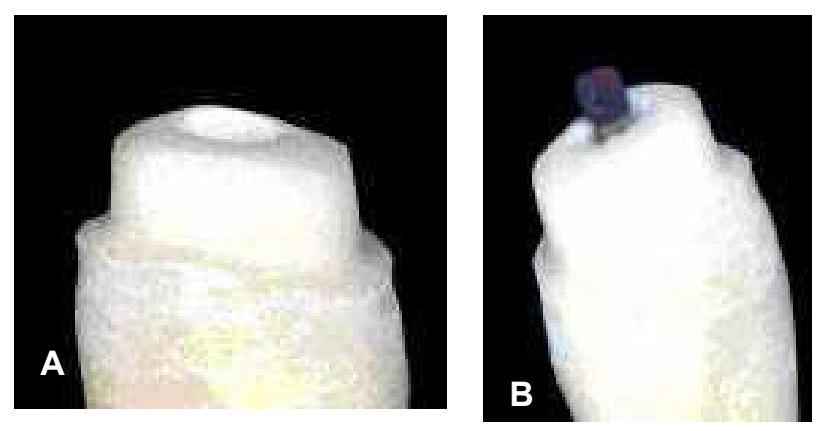

FIGURA 3 - Preparo dos condutos
A) preparo concluído;
B) prova do pino pré-fabricado.

\subsection{CimentaÇÃo dos Pinos}

Após o preparo do conduto, este foi limpo com uma lima envolta em algodão embebido em álcool, lavado com água e secado com jatos de água/ar. Os pinos pré-fabricados (Figura 4A) foram cimentados com cimento de fosfato de zinco de acordo com as recomendações do fabricante. Completada a mistura, o cimento era levado ao interior do conduto por uma broca Lentulo (Figura 4B) e aplicado no núcleo com pincel (Figura 4C-D) n. $2^{60,116}$ e este era assentado passivamente com pressão mantida a $5 \mathrm{~kg}$ por 10min. Após o tempo de presa do cimento, confeccionou-se o núcleo de preenchimento. 

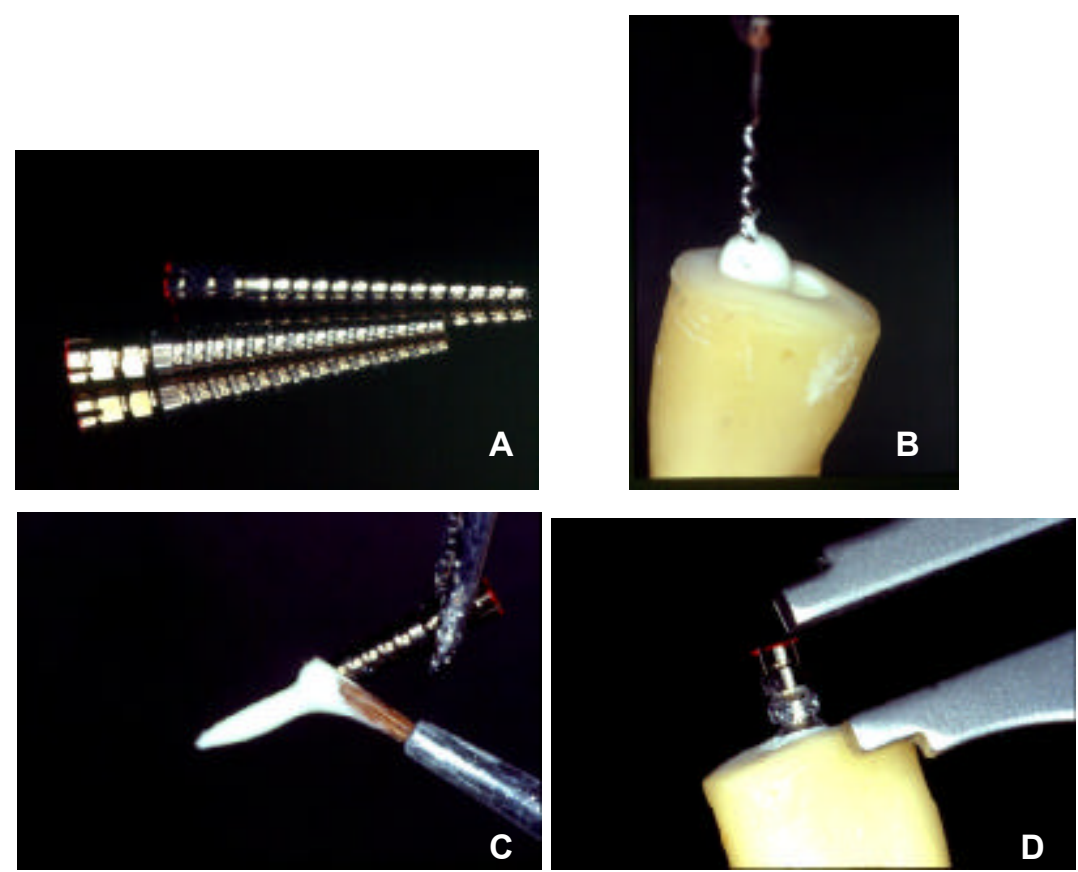

FIGURA 4 - Cimentação dos pinos intra-radiculares
A) pino Unimetrik (Destsply/Caulk);
B) broca lentulo preenchendo o conduto com cimento;
C) cimento sendo aplicado no pino, com pincel;
D) padronização da porção coronária do pino em $4 \mathrm{~mm}$, com paquímetro.

\subsection{Confecção dos Núcleos de Preenchimento}

\subsubsection{OBtenção das matrizes de Plástico}

Os núcleos de preenchimento foram obtidos por meio de matrizes plásticas, a fim de padronizar suas dimensões.

As matrizes plásticas foram obtidas a partir de moldes da porção coronária e radicular, remanescentes de amostras piloto, com silicona de adição (Express $3 \mathrm{M}$ ) vazados com resina acrílica autopolimerizável Duralay (Reliance Dental Mfg. Co. Worth, IL, USA) e fundidos com ligas à base de Cu-Al (Goldent - AJE Comércio Importação e Exportação Ltda). Após a 
obtenção deste padrão metálico dos dentes preparados, os mesmos foram levados a uma máquina plastificadora a vácuo (Bioart) e reproduzidas 40 matrizes de acetato, que serviram para a reconstrução da porção coronária em resina (Figura 5).
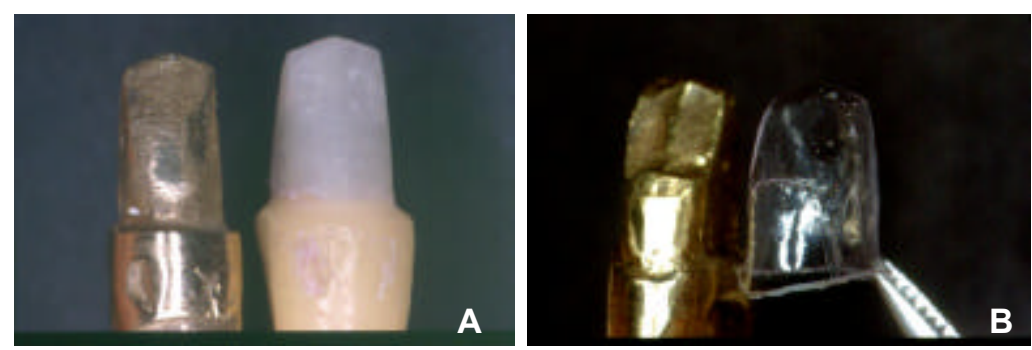

FIGURAS 5 - Confecção das matrizes de polietileno

A) padrão de fundição obtido a partir da moldagem do núcleo confeccionado no estudo piloto;

B) matriz à vácuo obtida a partir do troquel metálico.

\subsubsection{InSERÇÃo da Resina de Preenchimento}

A seqüência restauradora foi realizada de acordo com as características estabelecidas para cada grupo.

A estrutura dental coronária de todos os espécimes foi condicionada com ácido fosfórico por 15 segundos; a superfície tratada foi avada com jatos de água por 20 segundos e os excessos removidos com discos de papel absorvente. Em seguida, com a dentina úmida, procedeurse a aplicação do sistema adesivo Single Bond para os grupos reconstruídos com Z-250. Aplicou-se uma primeira camada com pincel, pelo tempo de 20 segundos, seguido de uma segunda camada, esperando-se 30 segundos para evaporação do solvente. A seguir, jatos de ar foram aplicados por 5 segundos, seguindo-se de fotoativação por 20 segundos $^{8}$, com foto ativador Ultra lux (Dabi Atlante). A resina composta (cor A 3,5) foi inicialmente adaptada em camadas em torno do pino pré-fabricado, e cada camada 
fotoativada por 20 segundos, em incrementos de aproximadamente $2 \mathrm{~mm}$ de espessura. As matrizes plásticas foram preenchidas com a resina composta e posicionadas sobre a porção coronária do pino. Os excessos foram removidos e a resina recebeu a suplementação de fotoativação durante 40 segundos em cada face. Após a polimerização, as matrizes de plásticos foram seccionados, obtendo-se assim os núcleos de preenchimento. As amostras foram armazenadas, em soro fisiológico a 0,9\% até a realização dos testes de resistência à fratura (Figura 6).
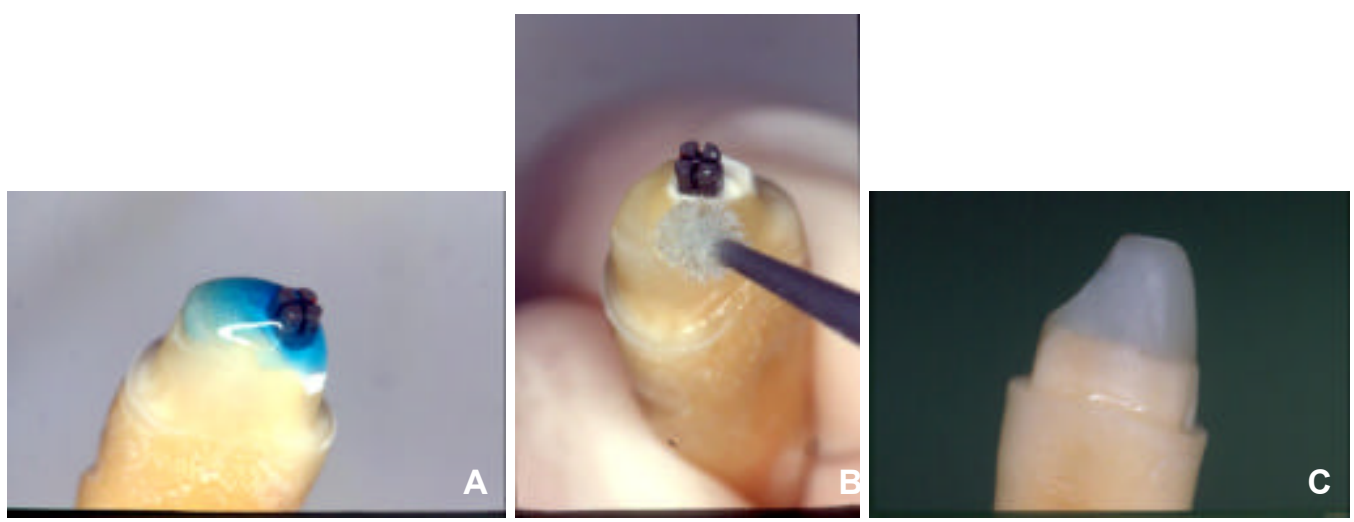

FIGURA 6 - Confecção dos núcleos de preenchimento com remanescente coronal

A) condicionamento ácido com $\mathrm{H}_{3} \mathrm{PO}_{4}$ a $37 \%$;

B) aplicação do adesivo;

C) núcleo de preenchimento em resina composta.

Para a resina dual Enforce Core, após o tratamento da dentina, foi aplicado o sistema adesivo pelo tempo de 30 segundos, e uma segunda camada por 30 segundos, seguindo-se a fotoativação por 20 segundos. A resina composta foi inserida dentro das matrizes de plástico, posicionadas sobre a porção coronária do pino, e fotoativada por 20 segundos. Os excessos foram removidos e a resina fotoativada durante 20 segundos em cada face. Após a polimerização, os moldes plásticos foram seccionados, retirados, e os excessos removidos Da mesma maneira, após a obtenção dos padrões, os mesmos foram armazenados em soro fisiológico a 0,9\%. 

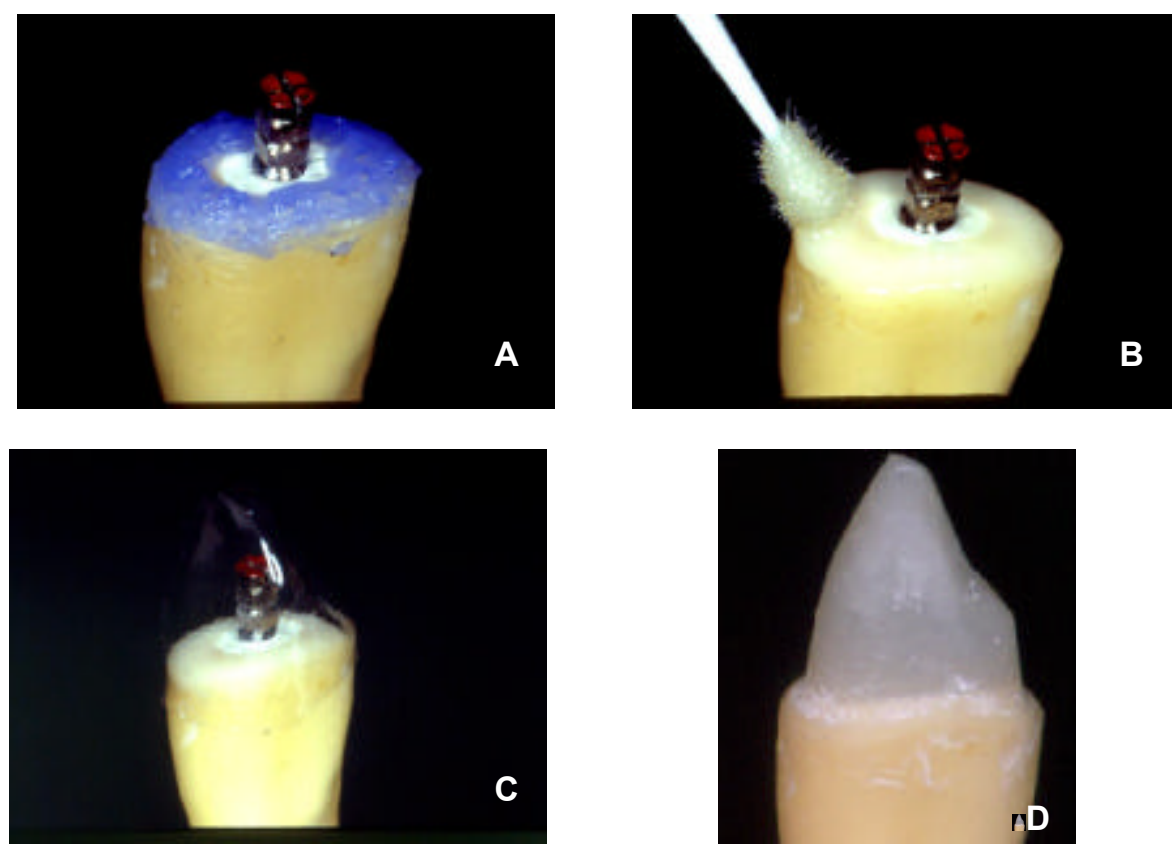

FIGURA 7 - Confecção dos núcleos de preenchimento sem remanescente coronal
A) etapa de condicionamento ácido;
B) aplicação do adesivo;
C) adaptação da matriz de polietileno;
D) núcleo de preenchimento em resina composta.

\subsection{INCLUSÃO DOS DENTES}

Após a reconstrução,os dentes foram fixados em cilindros de resina autopolimerizável apresentando altura de $30 \mathrm{~mm}$ e $22 \mathrm{~mm}$ de diâmetro, e posteriormente levados à máquina de ensaios para testes.

\subsection{ENSAIO DE RESISTÊNCIA À FRATURA (FORÇAS APLICADAS EM 45)}

A resistência à fratura foi avaliada em máquina de ensaios universal (Dinamômetros KRATOS Ltda, São Paulo - Brasil) através de carregamento de compressão, incidindo em ângulo de $135^{\circ}$ com o longo eixo da raiz 
(ângulo de 45 em relação ao plano horizontal) simulando o contato do dente antagonista em relação oclusal de classe I (Figura 8). Esta angulação foi obtida por meio de um dispositivo o qual permite regulagem tanto do ângulo como de sua base, adaptando-se ao espécime a ser testado (Figura 9). Utilizou-se célula de carga 1 , escala $\mathrm{n} .2$ e velocidade de $0,5 \mathrm{~mm} / \mathrm{min}^{61,83,87}$.

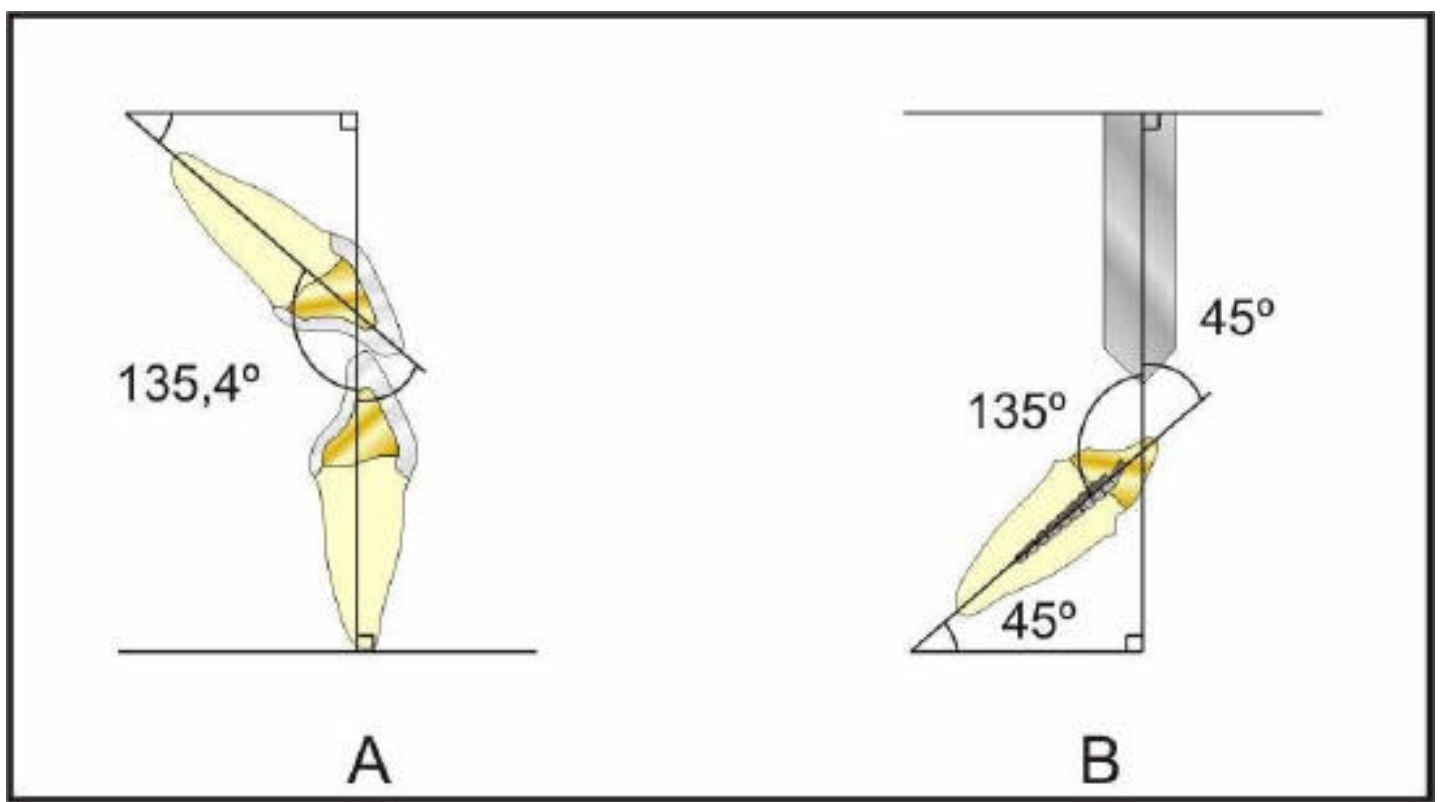

FIGURA 8 - Esquema da aplicação de força à $45^{\circ}$

A) ângulo de $135,4^{\circ}$ formado pelo contato entre os incisivos centrais s uperiores e inferiores quando em relação oclusal de classe I);

B) representação esquemática do carregamento de compressão incidindo em ângulo de $135^{\circ} \mathrm{em}$ relação ao longo eixo da raiz, ou seja, com o espécime formando um ângulo de $45^{\circ}$ em relação ao plano horizontal.

Para aplicação de forças em $4^{\circ}$ nos testes de resistência, desenvolveurse um dispositivo especial que se adaptava à porção inferior da máquina de ensaios. Neste dispositivo, foi torneado um outro orifício, onde se colocava o cilindro de plástico/núcleo de preenchimento, para os ensaios.

A posição do cilindro permitia ao núcleo ficar posicionado em uma inclinação de 45․ Na porção superior da máquina, adaptourse uma ponta ativa, posicionada na porção palatina do núcleo de preenchimento, gerando uma força compressiva. Quando acionada a máquina de ensaios, se 
anotavam os valores, que eram organizados em tabelas para futuro tratamento estatístico. Os valores em $\mathrm{kgF}$ foram analisados estatisticamente pelos testes de ANOVA 2 critérios e Tukey.
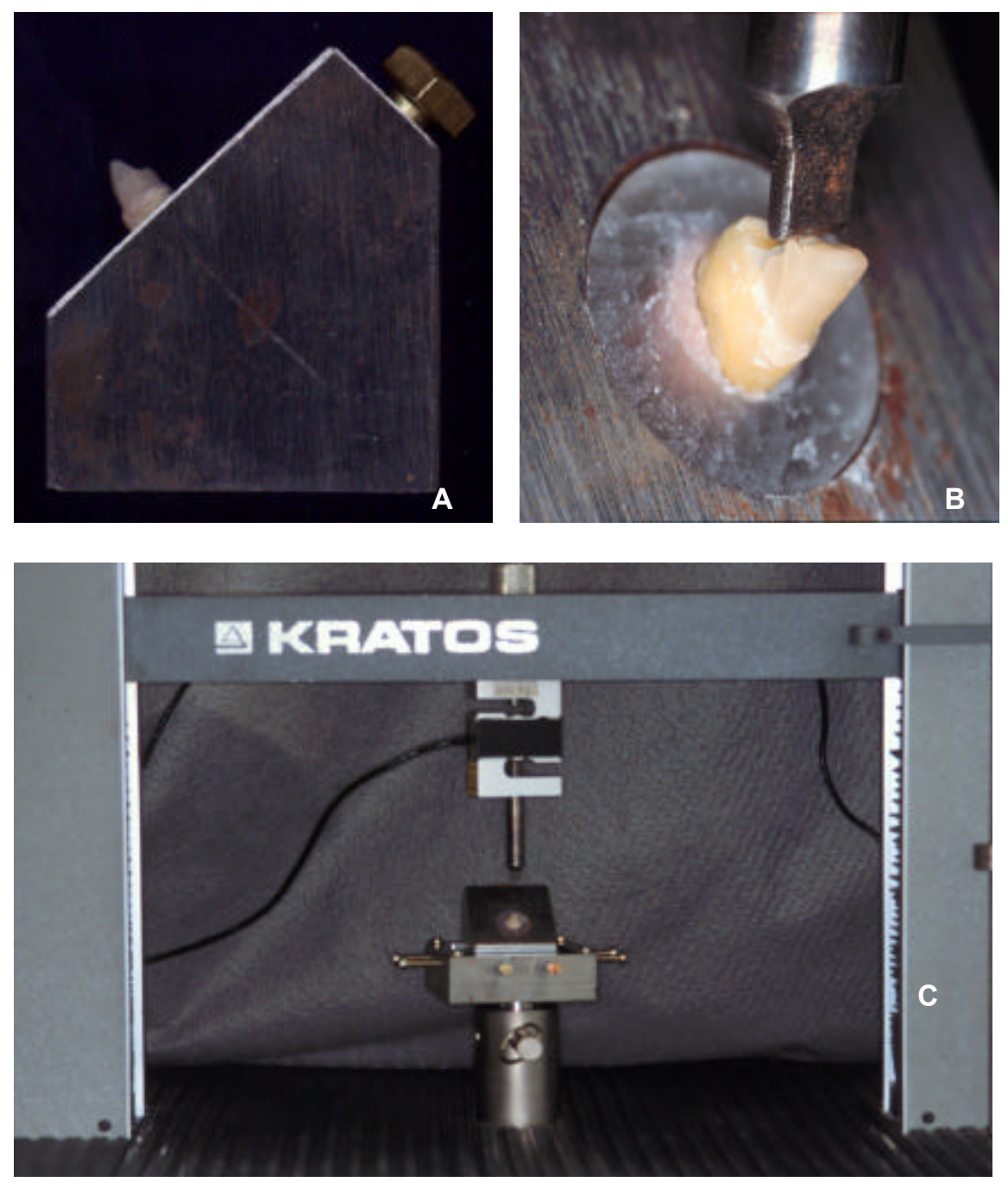

FIGURA 9 - Visualização do aparato utilizado para a fixação e posicionamento dos corpos de prova submetidos ao teste de resistência à fratura em uma máquina universal de ensaios
A) dispositivo $45^{\circ}$;
B) força sendo aplicada na superfície palatina;
C) máquina Kratos. 
5 RESULTADOS 


\section{RESULTADOS}

As médias e desvios-padrão de cada grupo estudado são apresentados na Tabela 2.

Para a análise dos resultados, fez-se uso do teste de Análise de Variância (ANOVA) a dois critérios, $\mathrm{p}<0,05$ (Tabela 3). Notou-se diferença estatisticamente significativa entre os grupos; a comparação das médias foi feita através do teste de Tukey para comparações múltiplas, $p<0,05$. (Tabela 4).

TABELA 2 - Valores individuais, médias e respectivos desvios-padrão para cada condição experimental (valores em kgf)

\begin{tabular}{ccccc}
\hline ESPÉCIME & $\begin{array}{c}\text { GRUPOI } \\
\text { Enforce Core } \\
\text { com remanescente }\end{array}$ & $\begin{array}{c}\text { GRUPOII } \\
\text { Z-250 } \\
\text { com remanescente }\end{array}$ & $\begin{array}{c}\text { GRUPO III } \\
\text { Enforce Core } \\
\text { sem remanescente }\end{array}$ & $\begin{array}{c}\text { GRUPOIV } \\
\text { Z-250 } \\
\text { sem remanescente }\end{array}$ \\
\hline $\mathbf{1}$ & 38,50 & 65,40 & 54,50 & 45,30 \\
$\mathbf{2}$ & 53,70 & 50,70 & 53,60 & 58,15 \\
$\mathbf{3}$ & 55,25 & 37,70 & 45,10 & 36,60 \\
$\mathbf{4}$ & 34,10 & 39,40 & 52,80 & 66,70 \\
$\mathbf{5}$ & 54,05 & 72,45 & 40,30 & 58,70 \\
$\mathbf{6}$ & 34,20 & 48,15 & 51,80 & 56,60 \\
$\mathbf{7}$ & 40,65 & 58,40 & 33,85 & 49,45 \\
$\mathbf{8}$ & 56,70 & 81,00 & 37,05 & 63,20 \\
$\mathbf{9}$ & 45,50 & 78,25 & 63,25 & 55,35 \\
$\mathbf{1 0}$ & 59,30 & 47,50 & 48,45 & 79,00 \\
\hline Média & $\mathbf{4 7 , 1 9}$ & $\mathbf{5 7 , 9 0}$ & $\mathbf{4 8 , 0 0}$ & $\mathbf{5 6 , 9 1}$ \\
\hline Desvio & $\mathbf{9 , 7 3}$ & $\mathbf{1 5 , 7 1}$ & $\mathbf{9 , 0 2}$ & $\mathbf{1 1 , 7 1}$ \\
Padrão & & & & \\
\hline
\end{tabular}

Com relação aos grupos com e sem remanescente os resultados mostraram não haver diferença estatisticamente significativa entre estes 
grupos; não ocorre o mesmo em relação ao tipo de material de preenchimento utilizado (Tabela 3).

TABELA 3 - Teste estatístico de análise de variância a dois critérios, aplicado aos valores de resistência à fratura

\begin{tabular}{lcccccc}
\hline \multicolumn{1}{c}{ Efeito } & $\begin{array}{c}\text { gl } \\
\text { Efeito }\end{array}$ & $\begin{array}{c}\text { QM } \\
\text { Efeito }\end{array}$ & $\begin{array}{c}\text { gl } \\
\text { Efeito }\end{array}$ & $\begin{array}{c}\text { QM } \\
\text { Efeito }\end{array}$ & $\mathbf{F}$ & $\mathbf{p}$ \\
\hline Material & $1^{*}$ & $954,0406^{*}$ & $36^{*}$ & $139,9787^{*}$ & $6,815613^{*}$ &, $013089^{*}$ \\
Remanescente & 1 &, 0331 & 36 & 139,9787 &, 000236 &, 987823 \\
Interação & 1 & 8,6956 & 36 & 139,9787 &, 062121 &, 804592 \\
\hline
\end{tabular}

* estatisticamente significativo $(p<0,05)$

A Tabela 4 apresenta o padrão de fratura dos espécimes.

TABELA 4 - Comparações individuais - Teste de Tukey

\begin{tabular}{lccc}
\hline \multicolumn{1}{c}{ MATERIAL } & MEDIA & $\mathbf{1}$ & $\mathbf{2}$ \\
\hline Enforce & 47,632 & $\mathrm{x}$ & \\
Z-250 & 57,400 & & $\mathrm{X}$ \\
\hline
\end{tabular}

$x$ diferença estatisticamente significativa $(p<0,05)$ 


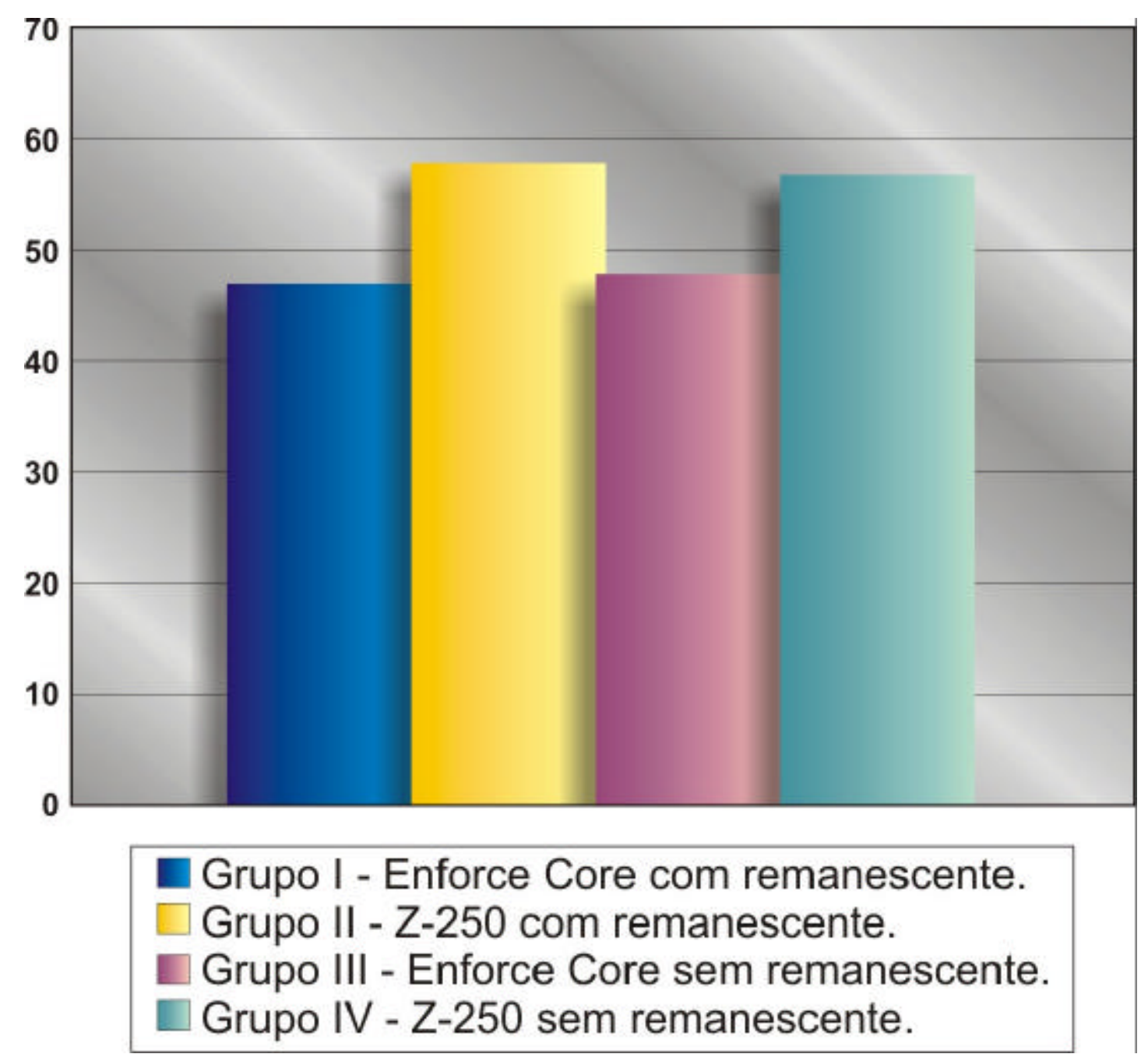

FIGURA 10 - Representação gráfica das médias de resistência à fratura dos quatro grupos experimentais

$\mathrm{N} . \mathrm{S}=$ não significante ao nível de 5\%. 
6 DISCUSSÃO 


\section{DISCUSSÃO}

A restauração de dentes tratados endodonticamente que receberão pinos metálicos fundidos ainda é uma situação clínica comum nos consultórios odontológicos. O grande avanço do tratamento endodôntico nos dias atuais é o grande responsável pelo sucesso das restaurações protéticas: dentes antes condenados à extração, têm hoje seus condutos tratados e usados como suporte destas próteses.

Apesar do grande número de publicações científicas e dos mais variados materiais restauradores disponíveis no mercado, continua duvidosa a decisão sobre qual o melhor plano de tratamento a ser realizado com vistas à maior longevidade da restauração de um dente tratado endodonticamente.

Dentes tratados endodonticamente com grande perda de estrutura coronária necessitam ser reconstruídos por meio de métodos de retenção intra-radicular e coroas protéticas ${ }^{4,5,84,101,109,110}$, e, durante muitos anos, a restauração intra-radicular destes dentes tinha como único objetivo aumentar a resistência de suas raízes $9,10,47,104,117,116,125$.

Os núcleos metálicos fundidos são os mais tradicionais na odontologia restauradora, sendo indicados quando o dente apresenta estrutura dentária remanescente inadequada, servindo, de acordo com MORGANO ${ }^{85}$, como apoio a uma coroa que sobre ele será cimentada.

Entretanto, como alternativa de tratamento, recentemente ocorreu uma verdadeira invasão no mercado de vários tipos e marcas de pinos pré-fabricados fixados nos condutos, associados com núcleos de preenchimento e resina composta e recobrimento oclusal ${ }^{25,65}$. MORGANO ${ }^{85}$ comenta que os pinos pré-fabricados têm sido preferidos pela grande 
maioria dos profissionais norte-americanos, em detrimento do uso de núcleos metálicos fundidos pela rapidez de sua confecção.

De acordo com KANTOR; PINES ${ }^{62}$, DEUTSCH et al. $^{36}$, SORESEN; ENGELMAN $^{110}$, ASSIF et al. $^{4}$, a resistência de um dente despolpado restaurado pode estar na dependência do pino ou núcleo utilizado. FARAH; $\mathrm{KRAIG}^{40}$ relacionam esta resistência ao formato do término cervical. TROPE; MALTZ; TRONSTAD ${ }^{127}$ defendem que o principal fator relacionado à resistência é a quantidade de remanescente dentário presente. ASSIF; GORFIL $^{5}$, entende que a coroa total que recobre a porção coronária do pino garante a proteção da raiz contra à fratura, fazendo o efeito de férula.

O preparo de um conduto proporciona maior desgaste dentinário, enfraquecendo ainda mais a raiz $z^{4,5,77,80,91,98,110,125,126,127} \mathrm{e}$, dependendo do desenho do pino, poderão ocorrer tensões internas e efeito cunha durante sua inserção $27,59,110$. Estudos laboratoriais mostram que a resistência à fratura, de dentes tratados com núcleos fundidos, é menor do que com os pinos pré-fabricados $6,23,45,5365,124$. Estudos clínicos longitudinais mostram maior índice de falhas para núcleos metálicos fundidos quando comparados aos pinos pré-fabricados ${ }^{69,111,124}$. TORBJÖRNER; KARKSSON; ODMAN ${ }^{124}$ afirmaram que tratamentos com pinos metálicos são 2,5 vezes mais susceptíveis à fratura do que dentes restaurados com pinos pré-fabricados. Assim, de acordo com ASSIF; GORFIL ${ }^{5}$, o objetivo de um pino intra-radicular fundido ou pré-fabricado é apenas proporcionar retenção à futura restauração, devendo sua seleção ser baseado em um sistema que preserve o máximo possível a estrutura dentária, com retenção adequada para a restauração coronária do dente $e^{4,19,27,36,82,88,98,111,113,114,132}$. Um retentor intra-radicular só deve ser indicado quando outras formas de retenção e resistência não forem suficientes para suportar a restauração final $^{71,77,79,109,110}$.

Estão disponíveis para o mercado pinos pré-fabricados com diferentes formas: paralelos, cônicos, lisos e rosqueáveis. Os pinos paralelos e rosqueáveis são considerados os mais retentivos ${ }^{117}$, na proporção em que 
se aumenta seu comprimento e o diâmetro ${ }^{117,127}$. A escolha de pinos mais longos e delgados possibilita uma melhor distribuição de tensões ${ }^{54,89}$ preservando uma estrutura dental sadia ${ }^{125}$. Os pinos com extremidade cônica permitem um maior volume de dentina na porção média e apical da raiz $^{25}$, sendo porém menos retentivos. Características superficiais, como canaletas e sulcos de escape, são importantes para diminuir a pressão hidrodinâmica durante a cimentação ${ }^{56}$ e melhorar sua retenção.

Foram selecionados para este estudo pinos de titânio cônico passivo, pelo fato de ter apresentado resultados favoráveis em testes laboratoriais de resistência e tração ${ }^{30,61,64}$. Além disso, são biocompatíveis, não sofrem corrosão, resistem às cargas mastigatórias e há relatos de uso com sucesso em acompanhamentos a longo prazo ${ }^{36,85}$. Permitem, ainda, preservação de estrutura dentária na região apical pelo fato de se adequar melhor à configuração do canal radicular e exercem concentrações mais baixas de força de tensão, provavelmente devido à ausência de ângulos agudos ${ }^{5,107}$. A superfície serrilhada promove melhor resistência ao deslocamento em relação aos pinos com superfície lisa.

A combinação pino pré-fabricado e núcleo de preenchimento com resina composta é mais simples e prática, porque a resina composta é facilmente colocada no local desejado, polimerizada em curto espaço de tempo, permitindo o preparo imediato para a coroa na mesma sessão ${ }^{33}$, fato este também observado durante a fase laboratorial do nosso trabalho.

Um dos principais motivos de insucesso ao utilizarmos retentores intra-radiculares é a fratura do elemento dentário remanescente. Com o objetivo de prevenir este tipo de insucesso é importante a observação dos princípios biomecânicos básicos, relacionados com as restaurações, para que, com isso, se possa adotar técnicas e empregar materiais que ofereçam retenção, estabilidade e restituam a resistência do elemento dental, podendo exercer suas funções individualmente, ou como suporte de prótese fixa, ou removível ${ }^{13,27}$. Desta forma as restaurações poderão absorver, suportar e transmitir as cargas que são aplicadas sobre as estruturas de suporte, além 
de manter-se em posição sem deslocar, durante os esforços mastigatórios. O processo de confecção de um núcleo intra-radicular é o passo que causa maior injúria durante procedimentos restauradores de dentes despolpados ${ }^{75,123}$ e o planejamento inadequado poderá levar à fratura ou ao deslocamento do remanescente dentário durante a função, demonstrando sua incapacidade de resistir às forças a que são submetidas.

A principal causa atribuída à fragilidade de um dente despolpado é a perda de umidade ${ }^{5,13,36,41,46,61,101,124}$. GUTMANN ${ }^{46}$ ensinou que em um dente despolpado a umidade da dentina coronária diminuí para 13,2\% e a perda de umidade na dentina radicular é ainda maior. Desta forma o dente desidratado teria sua capacidade de deformação elástica diminuída ${ }^{46,55}$, devendo-se realizar uma restauração que, além de substituir a estrutura perdida, devolvesse a resistência adequada ao remanescente dentário. No entanto, vários autores discordaram desta teoria, quando compararam dentes homólogos vitais e não vitais em relação à umidade da dentina remanescente, onde não encontraram diferenças ${ }^{102}$. Outros estudos comprovam que não ocorrem mudanças no módulo de elasticidade, na dureza ou na resistência à fratura de dentes despolpados $3,5,102,107,108,139$. Alguns autores, entre eles TRABERT; CAPUT; ABOU-RASS ${ }^{125}$, SORENSEN; MARTINOFF ${ }^{108}$, afirmaram que a resistência à fratura dos dentes tratados endodonticamente diminuí apenas $5 \%$ em relação ao dente vital. Contudo, existe o consenso de que é fundamental a preservação das estruturas radicular e coronária remanescentes para melhor prognóstico restaurador, pois a perda de estruturas importantes como cristas marginais e pontes de esmalte enfraquecem significativamente os dentes polpados e despolpados ${ }^{36,46,76,80,83,84,102,119}$. Preocupado com isso, DEUTSCH et al. ${ }^{37}$ alertaram que as causas que levam à fratura não são completamente definidas porque os princípios não estão claros em relação ao procedimento de preparo radicular e utilização de pinos e núcleos de preenchimento.

Acreditava-se, há pouco tempo atrás, que um pino intra-radicular era capaz de reforçar um dente tratado endodonticamente ${ }^{9,10,70,104}$, porém este 
princípio não é mais aceito, pois várias pesquisas contradizem esta teoria $^{5,47,55,79,91,109,110,111,119,127,130}$.

GUZY; NICHOLLS ${ }^{47}$, compararam a resistência de dentes tratados endodonticamente com ou sem pinos, concluindo que os pinos não aumentaram a resistência dos dentes. Correlacionando um estudo clínico e laboratorial, SORENSEN; MARTINOFF ${ }^{111}$, em 1984, não encontraram evidências para afirmar que um pino intra-radicular realmente reforce um dente. Outros autores como TROPE; MALTZ; TRONSTAD ${ }^{127}$ afirmaram que a introdução de um pino intra-radicular pode enfraquecer o dente pois 0 preparo do conduto enfraquece seriamente o dente, o que não é recompensado pela introdução deste pino. Estes mesmos autores não encontraram diferença em estudo laboratorial onde empregaram núcleos de amálgama com e sem pinos no canal radicular. O mesmo ocorreu com PLASMANS et al. ${ }^{93}$, comparando núcleos de resina composta com e sem pinos.

É importante ressaltar que, segundo alguns autores ${ }^{47,109,125,127}$, dentes anteriores intactos, com acesso endodôntico conservador e cristas marginais intactas, não precisam de pinos ou cobertura coronária. CRISTENSEN ${ }^{25}$, ensinou que a restauração protética de dentes tratados endodonticamente com perda mínima de estrutura dental deve ser realizada sem a colocação de pinos; e que estes só deveriam ser utilizados em casos extremos, onde os dentes perderam mais da metade da coroa dental. SORENSEN et al. ${ }^{113}$, conclui que quando houver menos da metade de remanescente dentário coronal, um pino ou núcleo deve ser indicado. Autores como PLASMANS et al. ${ }^{93}$ consideram que um pino pode ser necessário para possibilitar a rete nção da resina composta como material de preenchimento.

No presente estudo, optourse pela utilização de um pino de $15 \mathrm{~mm}$, dos quais $11 \mathrm{~mm}$ dentro do canal radicular. Para a desobstrução deste, fezse uso de uma broca correspondente ao pino, de acordo com o Kit Unimetric, o que permitiu com que houvesse uma padronização dos 
preparos, removendo-se a menor quantidade de estrutura dental possível, seguindo-se os princípios de preservação de estrutura dentária ${ }^{19,59,125}$.

Uma grande dúvida ainda permanece entre os cirurgiões dentistas em relação à quantidade de estrutura dentária coronal necessária para prover a resistência suficiente para suportar as forças exercidas sobre o conjunto dente/restauração e, mais, se a resistência do dente é maior quando existe uma maior quantidade deste remanescente. Por isso, este trabalho procurou avaliar se a quantidade de remanescente dentário coronal influi na resistência à fratura de dentes tratados endodonticamente.

Os resultados encontrados no presente trabalho mostraram não haver diferenças estatisticamente significativas, quando comparados dentes sem remanescente ou com $3 \mathrm{~mm}$ de remanescente dentino-coronal em altura (Grupos: I - 47,19 Kgf; II - 57,90Kgf; III - 48,00Kgf e IV - 56,91Kgf).

Estes resultados estão de acordo com SORENSEN; ENGELMAN ${ }^{109}$ que verificaram não haver diferenças significantes ao estudar a resistência de dentes tratados endodonticamente com e sem remanescente coronal; porém, ISIDOR; BRONDUM; RAVNHOLT ${ }^{58}$ contradizem estes resultados.

Apesar dos resultados mostrarem, por meio da análise de variância a dois critérios, não haver diferença estatisticamente significante entre os Grupos I e II, o mesmo não ocorreu em relação ao tipo de material de preenchimento utilizado. Os grupos onde se utilizou a resina composta Z-250 obtiveram o melhor desempenho, com maior valor médio de resistência à fratura de 57,40 Kgf. Este valor foi estatisticamente significante $p<0,05$ em relação à média apresentada pelos grupos onde se utilizou Enforce Core com média de 47,63 Kgf.

As resinas compostas têm sido amplamente utilizadas para restauração de dentes anteriores e posteriores, por conferir excelente estética, preservação de estrutura dental e adequada resistência mecânica ${ }^{1,3}$. Em virtude destas propriedades, os compósitos de carga inorgânica híbrida são amplamente utilizados em restaurações que exigem 
cargas mastigatórias ${ }^{1,3}$. Tradicionalmente, os materiais empregados para restaurações eram os mesmos para núcleos de preenchimento; porém, nos últimos anos, materiais específicos para este fim foram desenvolvidos ${ }^{33}$, como é o caso do Enforce Core, utilizado neste estudo. A resina composta continua sendo o material de preenchimento mais utilizado, e apresenta várias vantagens sobre os outros materiais: possuem adequada resistência à fratura, adesão à estrutura dentária, retenção ao pino, possibilitam o preparo imediato.

Para que as resinas compostas fiquem fortemente retidas à estrutura dental, em especial à dentina, é necessária a utilização de ácidos e sistemas adesivos, os quais promovem suficiente união para o sucesso da restauração ${ }^{1,3,7,51}$. Esta excelente capacidade de adesão das resinas compostas, quando empregadas em conjunto com sistemas adesivos de última geração, promovem entre as estruturas e o pino uma melhor retenção ${ }^{113}$.

LAMBRECHETS $^{66}$, relata que as resinas compostas apresentam algumas desvantagens, entre as quais se encontram a contração de polimerização e a necessidade de técnica incremental quando foto-ativadas, e não serem dimensionalmente estáveis em ambiente úmido. Embora nos dias atuais a resina composta seja o principal material de escolha para núcleos de preenchimento, autores como ZALKIND; HOCHMAN ${ }^{132}$ aconselham o seu uso somente se houver suporte dentinário, não sendo indicada quando há perda total do remanescente coronário. Dessa maneira, decidimos comparar a resistência de diferentes materiais utilizados como núcleos de preenchimento em dentes com ou sem remanescente dentário coronal. Utilizou-se uma resina de cura dual específica para núcleo de preenchimento denominada Enforce Core (Dentsply/Caulk - cuja composição e carga são mantidas em segredo pelo fabricante), associada ao sistema adesivo dentinário hidrófilo Prime Bond (Dentsply/Caulk) e uma resina Z-250 da 3M, que é um compósito fotopolimerizável radiopaco composto por zircônia/sílica, e cuja carga inorgânica representa $60 \%$ do volume (sem silano) com um tamanho médio de partículas de 0,6 $\mu \mathrm{m}$ 
(oscilando na faixa entre 0,01 e $3,50 \mu \mathrm{m}$ ) associado a um sistema adesivo Single Bond.

A análise dos resultados demonstrou não haver diferença estatística na resistência à fratura entre os grupos com e sem remanescente; porém houve evidências de que o tipo de resina pode influenciar a resistência à fratura, bem como o modo de fratura, pelo fato da resina composta Z-250 ter-se mostrado significantemente mais resistente que a resina Enforce Core $(17,1 \%)$.

Sabe-se que um dos fatores críticos da utilização da resina composta fotopolimerizável é a interface adesiva, podendo esta ser comprometida pelo estresse gerado devido à contração de polimerização do materia| ${ }^{20}$. A inserção, pela técnica incremental, respeitando o fator de configuração cavitária, tem sido sugerida para minimizar os efeitos de contração de polimerização.

A técnica de inserção por incremento único, apesar de reduzir o tempo de trabalho clínico, exige um volume muito grande de material, e há possibilidade de inclusão de bolhas e vazios no interior da resina, como visto no trabalho realizado por MENTINK et al. ${ }^{81}$. Isto pôde ser confirmado após a realização do nosso trabalho, onde se observou a presença de bolhas dentro da resina; e estando estas quase sempre junto à linha de fratura, pode sugerir que sejam um dos fatores responsáveis pela menor resistência encontrada para o Enforce Core.

A composição química é um fator importante que poderia influenciar a resistência à compressão. Dependendo da composição química individual das resinas e sistemas adesivos, comportamentos diferentes podem ser esperados.

Para a realização dos testes de resistência à fratura, os corpos de prova eram encaixados num suporte metálico, a fim de se aplicar uma força a um ângulo de 45ํㅡ, com o longo eixo do dente minimizando todas as variáveis possíveis. 
A angulação de $45^{\circ}$ foi utilizada com 0 intuito de assemelhar-se 0 máximo possível com os tipos de forças que ocorrem na boca, das quais pode resultar uma associação de compressão e cisalhamento ${ }^{31,45,92,93,99}$. Especula-se que tenham sido KANTOR; PINES ${ }^{62}$, em 1977, os pioneiros na introdução de testes em núcleos metálicos com cargas compressivas aplicadas em 45ำ, em relação ao seu longo eixo, com a finalidade de simular as cargas oblíquas geradas durante a função incisal ou desoclusão do guia anterior.

Para que fosse possível submeter os dentes ao teste de fratura, eles foram incluídos em um corpo de prova de resina acrílica a $2 \mathrm{~mm}$ aquém do limite amelo-cementário ${ }^{47,73,109,110,125}$, altura onde se encontra normalmente a margem óssea alveolar. Durante sua inclusão, optou por não simular o ligamento periodontal, pelo fato do procedimento incorporar silicone; isto parece ser duvidoso para este procedimento, devido à falta de estudos que comprovem que este material apresenta as mesmas características de visco-elasticidade ${ }^{61}$.

A incapacidade do pino em reforçar estruturas dentais debilitadas pode ser explicada mecanicamente ${ }^{3,73}$. Como a força é aplicada pela face palatina do dente, o apoio é a crista óssea vestibular do rebordo alveolar. Isto provoca concentração de tensões de compressão na face vestibular do dente ${ }^{54,56}$, e, em oposição, há desenvolvimento de forças de tração na face palatina ${ }^{54}$. Estas forças contrárias se anulam no centro longitudinal do dente, exatamente onde está cimentado o pino intracanal. Quanto mais próximo da superfície do dente, maior a magnitude dessas tensões, o que indica a necessidade de reforço periférico e não no centro do dente ${ }^{56}$. Quando a carga aplicada sobre o dente ultrapassa o limite de proporcionalidade, pode iniciar-se uma trinca ou fratura, provavelmente na face palatina, onde os prismas de esmalte estão sob forças de tração. Essa linha de fratura pode se propagar no sentido transversal, do ponto de aplicação de carga ao ponto de apoio sobre a crista óssea ${ }^{73}$. 
O padrão de fratura descrito pode ser alterado quando há um pino que, cimentado no interior do canal radicular; ou seja, quando a Inha de fratura atinge a região do pino intra-canal, este dissipa parte das tensões através do seu corpo, dirigindo a trinca também no sentido longitudinal da raiz ${ }^{47}$. Somado a isso, CAILLETEAU; RIEGEL; AKIN ${ }^{17}$, em 1992, demonstraram que há variação na concentração de tensões em torno de um pino pré-fabricado; e existe a possibilidade de facilitação da ocorrência de fraturas radiculares. Este padrão de fratura não pode ser encontrado em nosso trabalho, pois, aqui, a grande maioria das fraturas se encontravam coronalmente e eram passíveis de serem restauradas, o que está de acordo com BEX et al. ${ }^{15}$ que salientaram que os núcleos de resina composta quando falham podem ser reparados, o que não acontece com materiais rígidos que levam, geralmente, à fratura radicular condenando o elemento dental.

O padrão de fratura poderia ser diferente sob condições mais reais, pois o carregamento aplicado foi contínuo e as forças excederam o carregamento exercido durante a mastigação ${ }^{72}$. No entanto, este estudo encontra correlação com o trabalho de ISIDOR; BRONDUM; RAVNHOLT ${ }^{58}$, em que se utilizou carga intermitente de baixa intensidade, semelhante ao que ocorre na cavidade oral. A observação do padrão de fratura demonstrou mais tendência a fraturas dos núcleos de preenchimento, para os grupos sem remanescente coronário; enquanto que nos grupos com remanescente o predomínio foi de fratura do remanescente em sentido longitudinal, porém reparável.

Foi possível observar, neste experimento, que os corpos de prova com resina dual Enforce Core tiveram um padrão de fratura localizado no núcleo de preenchimento e com uma aplicação de força menor, quando comparados com os núcleos de Z-250. Provavelmente isto ocorreu devido à técnica de inserção com a resina dual Enforce Core ter sido feita em um único incremento, originando bolhas internas e, desta forma, diminuindo sua resistência coesiva ${ }^{81}$. A resistência à fratura de materiais frágeis depende de fatores estruturais, como inclusão de bolhas de ar, trincas e distribuição de falhas na superfície e dentro dos espécimes. 
ASSIF et al. ${ }^{6}$ afirmaram que a resina composta, além de ser o material mais resistente para núcleos de preenchimento, apresenta também a vantagem de possuir módulo de elasticidade semelhante ao da dentina, o que propicia, a este material, gerar menos forças danosas à raiz.

Ao observarmos o modo de fratura ocorrido nos espécimes do Grupo II (Z-250), verificamos que $70 \%$ das amostras encontraram-se com seu remanescente coronário fraturado, porém passível de ser reparado. Isto pode ser atribuído, como explicam VERLUIS; TANTBIROJN; DOUGLAS ${ }^{129}$, à utilização da técnica incremental, pois esta poderia aumentar a deformação do dente levando a uma formação de dente/resina, com níveis mais altos de estresse em uma restauração, com adesão adequada. Além disso, os melhores resultados encontrados para a resina fotopolimerizável Z-250, segundo ABDALLA; ALHAYDAINY ${ }^{1}$, provavelmente ocorrem devido a grande quantidade de carga que possuem.

Nossos resultados estão de acordo com CÂNDIDO ${ }^{18}$, o qual constatou que a resina Z-250, em comparação às resinas indiretas Solidex e Artglass, apresentou o maior valor médio de microdureza superficial. $O$ autor sugeriu ainda uma aplicabilidade clínica de resina Z-250, devido as ótimas propriedades, como facilidade de manuseio e menor tempo de trabalho.

No presente trabalho $47,5 \%$ das falhas envolveram o núcleo de preenchimento, descontados os outros $32,5 \%$ envolvendo o conjunto núcleo de preenchimento/remanescente coronário, porém reparável. Esses resultados estão, também, em acordo aos encontrados por COHEN et al. ${ }^{29}$, que observaram que $79 \%$ das falhas ocorreram nos núcleos de preenchimento

Para melhor comparação dos resultados de trabalhos devemos levar em consideração se os testes de resistência são realizados diretamente sobre os núcleos de preenchimento ou sobre uma coroa total fundida cimentada sobre estes núcleos. Segundo HOAG; DWYER ${ }^{53}$ e GELFAND; GOLDMAN; SUNDERMAN ${ }^{45}$, quando testes de resistência à fratura são feitos sobre uma coroa total com margens em estrutura dental sadia, os 
materiais empregados como núcleo não exercem influência no resultado de resistência à fratura na amostra testada.

Tem-se especulado que o efeito férula aumenta significativamente a resistência dos dentes tratados endodonticamente à fratura, assim como a estabilidade da coroa instalada nesses dentes ${ }^{11,110}$.

Segundo ASSIF et al. ${ }^{4}$, o tipo de pino tem pouca influência na resistência à fratura do dente e não é tão importante quanto a presença de uma coroa total envolvendo a estrutura dentária sadia, abaixo da margem cervical do núcleo coronário. Ou seja, realiza-se a presença de um efeito férula envolvendo o término dos preparos. Desse modo, quando houver remanescente dental coronário suficiente para que $2 \mathrm{~mm}$ de estrutura dentária possa ser envolvida pelo preparo protético, haverá uma maior liberdade de opção entre os diferentes sistemas de retenção intra-radicular.

Pouco se sabe sobre a influência da quantidade de remanescente dentário coronal sobre a resistência de dentes tratados endodonticamente, Neste trabalho, embora não se tenha feito emprego de coroas totais para completa restauração dos dentes, o autor considera que os resultados encontrados foram relevantes porque a resistência dos dentes foi testada sob uma situação crítica, tal como já tinham concluído COHEN et al. ${ }^{33}$. Mesmo dentro dessas condições obtiveram-se resultados muitos satisfatórios, onde a força necessária para causar a falha do conjunto dente/restauração foi muito superior à média de resistência que os dentes caninos suportam na força de mordida máxima encontrada no estudo realizado por LYONS $^{72}$. Outros estudos devem ser realizados, a fim de elucidar a influência do remanescente dentário e do núcleo de preenchimento, quando estes estiverem recobertos por uma coroa.

O mais importante a se considerar é que o sucesso na reconstrução de dentes tratados endodonticamente, depende muito mais do remanescente dentário e sua implantação do que da escolha de um ou de outro sistema de retentores intra-radiculares. 
7 CONCLUSÕES 


\section{CONCLUSÕES}

A partir da análise dos resultados obtidos neste estudo pode-se concluir:

7.1. Não houve diferença estatisticamente significativa na resistência à fratura entre os dentes com e sem remanescente coronário;

7.2. Houve diferença significativa entre os resultados obtidos entre as resinas utilizadas;

7.3. Os grupos restaurados com Z-250 foram significativamente mais resistentes que os do Enforce Core. 
ANEXOS 


\section{ANEXOS}

TABELA 5 - Padrão de fraturas

\begin{tabular}{|c|c|c|c|c|}
\hline & GRUPO I & GRUPO II & GRUPO III & GRUPO IV \\
\hline Amostra & $\begin{array}{c}\text { Enforce Core } \\
\text { com remanescente } \\
\text { coronal }\end{array}$ & $\begin{array}{c}\mathrm{Z}-250 \\
\text { com remanescente } \\
\text { coronal }\end{array}$ & $\begin{array}{c}\text { Enforce Core } \\
\text { sem remane scente } \\
\text { coronal }\end{array}$ & $\begin{array}{c}\mathrm{Z}-250 \\
\text { sem remanescente } \\
\text { coronal }\end{array}$ \\
\hline 1 & $\begin{array}{l}(38.50) \\
\text { Fraturou a resina }\end{array}$ & $\begin{array}{c}\text { (65.40) } \\
\text { Fratura da resina e } \\
\text { do remanescente } \\
\text { reparável }\end{array}$ & $\begin{array}{l}\qquad(54.50) \\
\text { Fraturou a resina }\end{array}$ & $\begin{array}{l}(45.30) \\
\text { Deslocamento da } \\
\text { resina }\end{array}$ \\
\hline 2 & $\begin{array}{l}(53.70) \\
\text { Fratura da resina e } \\
\text { do remanescente } \\
\text { reparável }\end{array}$ & $\begin{array}{l}\quad(50.70) \\
\text { Fraturou a resina }\end{array}$ & $\begin{array}{l}(53.60) \\
\text { Fraturou a resina }\end{array}$ & $\begin{array}{l}(58.15) \\
\text { Fraturou a resina }\end{array}$ \\
\hline 3 & $\begin{array}{l}(55.25) \\
\text { Fratura da resina e } \\
\text { do remanescente } \\
\text { reparável }\end{array}$ & $\begin{array}{c}(37.70) \\
\text { Fraturou a resina }\end{array}$ & $\begin{array}{l}(45.10) \\
\text { Fraturou a resina }\end{array}$ & $\begin{array}{l}(36.60) \\
\text { Fraturou a resina }\end{array}$ \\
\hline 4 & $\begin{array}{c}(34.10) \\
\text { Fratura da resina e } \\
\text { do remanescente } \\
\text { reparável }\end{array}$ & $\begin{array}{l}(39.40) \\
\text { Fratura da resina e } \\
\text { do remanescente } \\
\text { reparável }\end{array}$ & $\begin{array}{l}(52.80) \\
\text { Fraturou a resina }\end{array}$ & $\begin{array}{l}(66.70) \\
\text { Fraturou a resina }\end{array}$ \\
\hline 5 & $\begin{array}{c}(54.05) \\
\text { Fraturou a raiz }\end{array}$ & $\begin{array}{l}(72.45) \\
\text { Fratura da resina e } \\
\text { do remanescente } \\
\text { reparável }\end{array}$ & $\begin{array}{l}(40.30) \\
\text { Fraturou a resina }\end{array}$ & $\begin{array}{l}(58.70) \\
\text { Fraturou a resina }\end{array}$ \\
\hline 6 & $\begin{array}{l}(34.20) \\
\text { Fratura da resina e } \\
\text { do remanescente } \\
\text { reparável }\end{array}$ & $\begin{array}{l}(48.15) \\
\text { Fratura da resina e } \\
\text { do remanescente } \\
\text { reparável }\end{array}$ & $\begin{array}{l}(51.80) \\
\text { Fraturou a resina }\end{array}$ & $\begin{array}{l}(56.60) \\
\text { Fraturou a resina }\end{array}$ \\
\hline 7 & $\begin{array}{l}(40.65) \\
\text { Fratura da resina e } \\
\text { do remanescente } \\
\text { reparável }\end{array}$ & $\begin{array}{l}(58.40) \\
\text { Fraturou a raiz }\end{array}$ & $\begin{array}{l}(33.85) \\
\text { Fraturou a raiz }\end{array}$ & $\begin{array}{l}(49.45) \\
\text { Fraturou a raiz }\end{array}$ \\
\hline 8 & $\begin{array}{l}(56.70) \\
\text { Fratura da resina e } \\
\text { do remanescente } \\
\text { reparável }\end{array}$ & $\begin{array}{l}(81.00) \\
\text { Fratura da resina e } \\
\text { do remanescente } \\
\text { reparável }\end{array}$ & $\begin{array}{l}(37.05) \\
\text { Fraturou a resina }\end{array}$ & $\begin{array}{l}(63.20) \\
\text { Fraturou a resina }\end{array}$ \\
\hline 9 & $\begin{array}{l}(45.50) \\
\text { Fraturou a resina }\end{array}$ & $\begin{array}{l}\text { (78.25) } \\
\text { Fratura da resina e } \\
\text { do remanescente } \\
\text { reparável }\end{array}$ & $\begin{array}{l}(63.25) \\
\text { Fraturou a resina }\end{array}$ & $\begin{array}{l}(55.35) \\
\text { Fraturou a raiz }\end{array}$ \\
\hline 10 & $\begin{array}{l}(59.30) \\
\text { Fraturou a raiz }\end{array}$ & $\begin{array}{l}(47.50) \\
\text { Fratura da resina e } \\
\text { do remanescente } \\
\text { reparável }\end{array}$ & $\begin{array}{l}(48.45) \\
\text { Fraturou a resina }\end{array}$ & $\begin{array}{l}(79.00) \\
\text { Deslocamento da } \\
\text { resina }\end{array}$ \\
\hline
\end{tabular}




\begin{tabular}{lcccc}
\hline Tipo de falha & $\begin{array}{c}\text { Fratura da } \\
\text { Resina }\end{array}$ & $\begin{array}{c}\text { Fratura } \\
\text { radicular }\end{array}$ & $\begin{array}{c}\text { Fratura da resina } \\
\text { e remanescente } \\
\text { reparável }\end{array}$ & $\begin{array}{c}\text { Deslocamento do } \\
\text { núcleo de } \\
\text { preenchimento }\end{array}$ \\
\hline GRUPO I & $20 \%$ & $20 \%$ & $60 \%$ & - \\
GRUPO II & $20 \%$ & $10 \%$ & $70 \%$ & - \\
GRUPO III & $90 \%$ & $10 \%$ & - & - \\
GRUPO IV & $60 \%$ & $20 \%$ & - & $20 \%$ \\
TOTAL & $\mathbf{4 7 , 5 \%}$ & $\mathbf{1 5 \%}$ & $\mathbf{3 2 , 5 \%}$ & $\mathbf{5 \%}$ \\
\hline
\end{tabular}



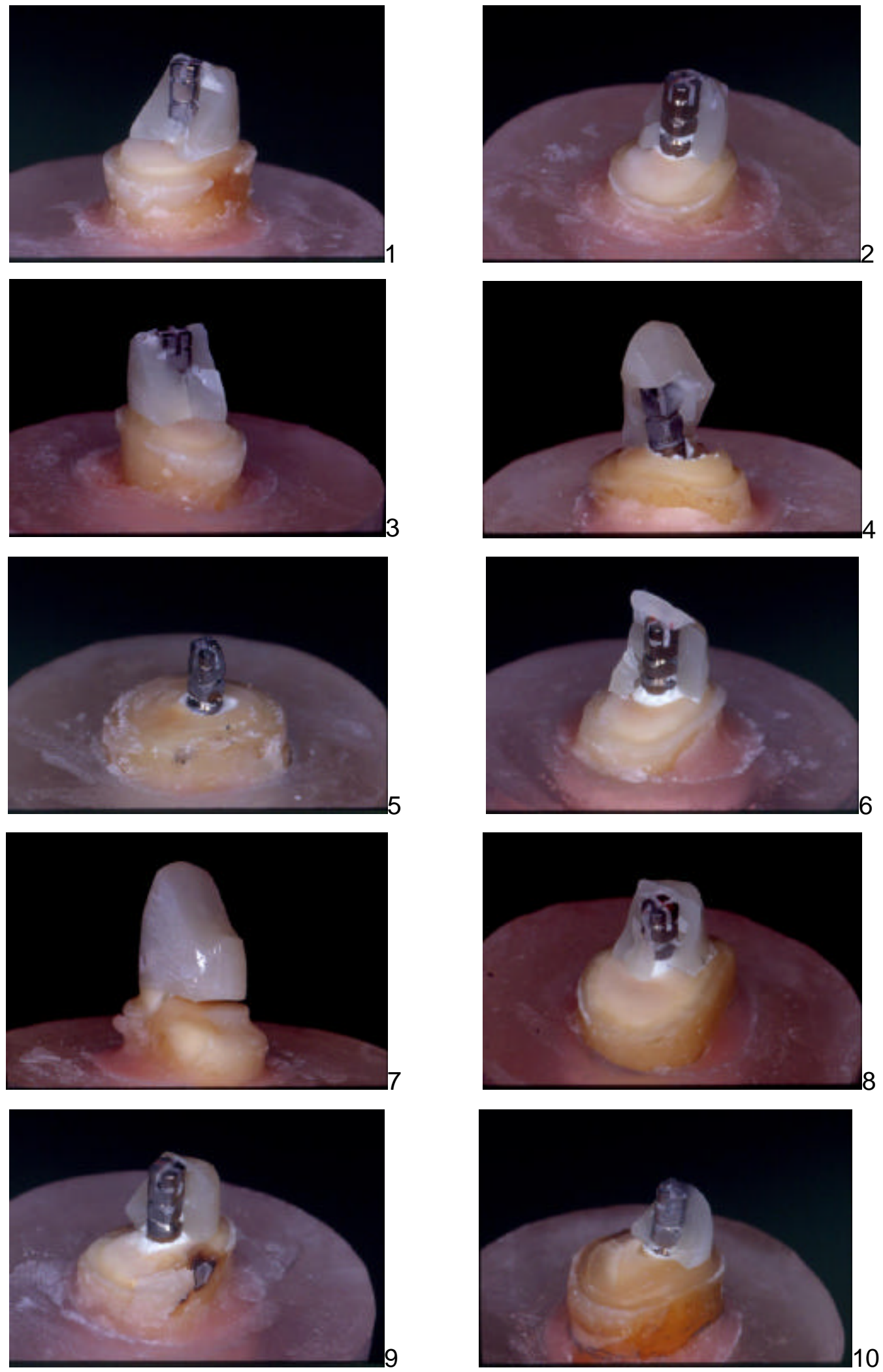

FIGURA 11 - Enforce Core sem remanescente coronal 

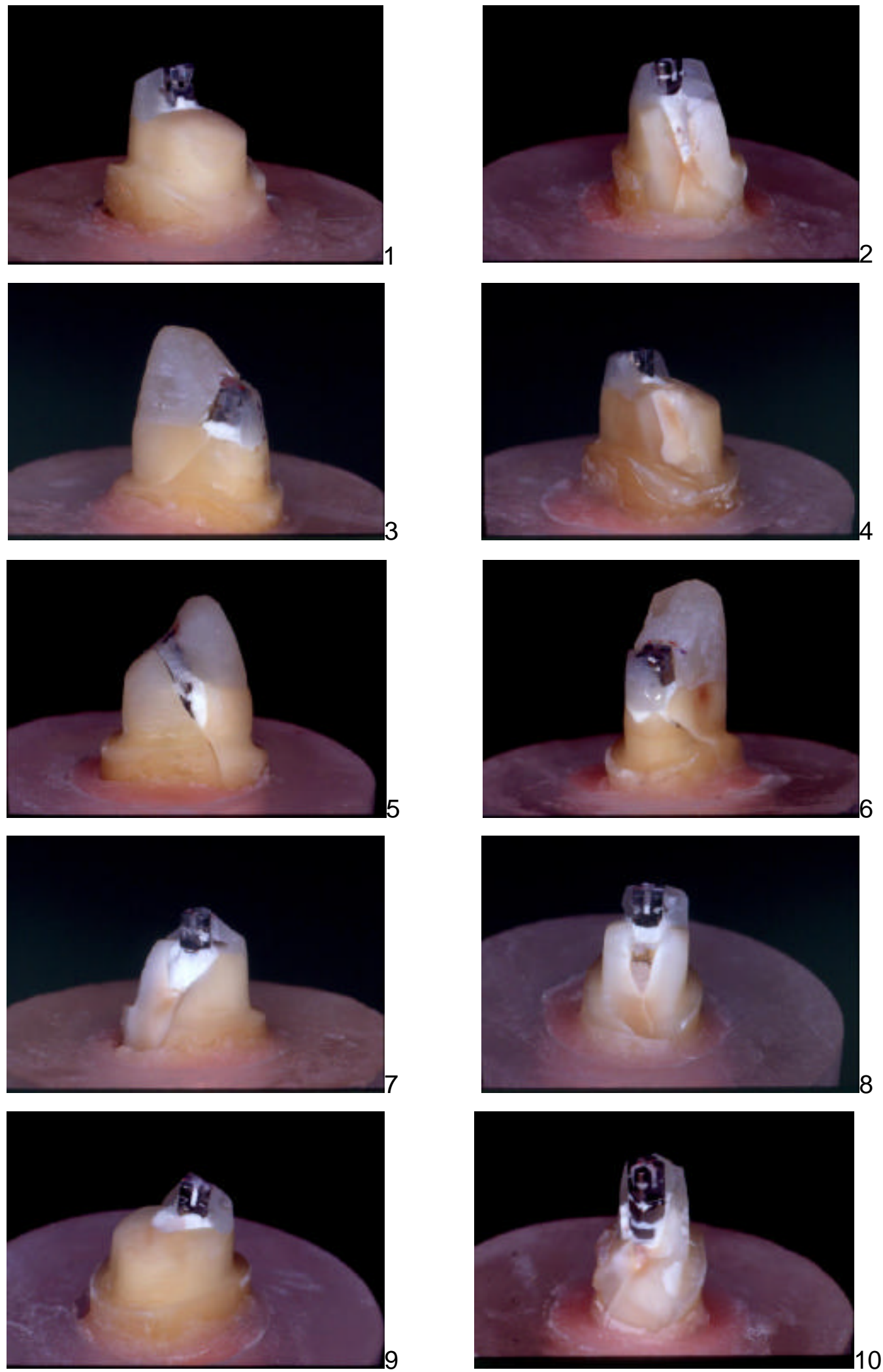

FIGURA 12 - Enforce Core com remanescente coronal 

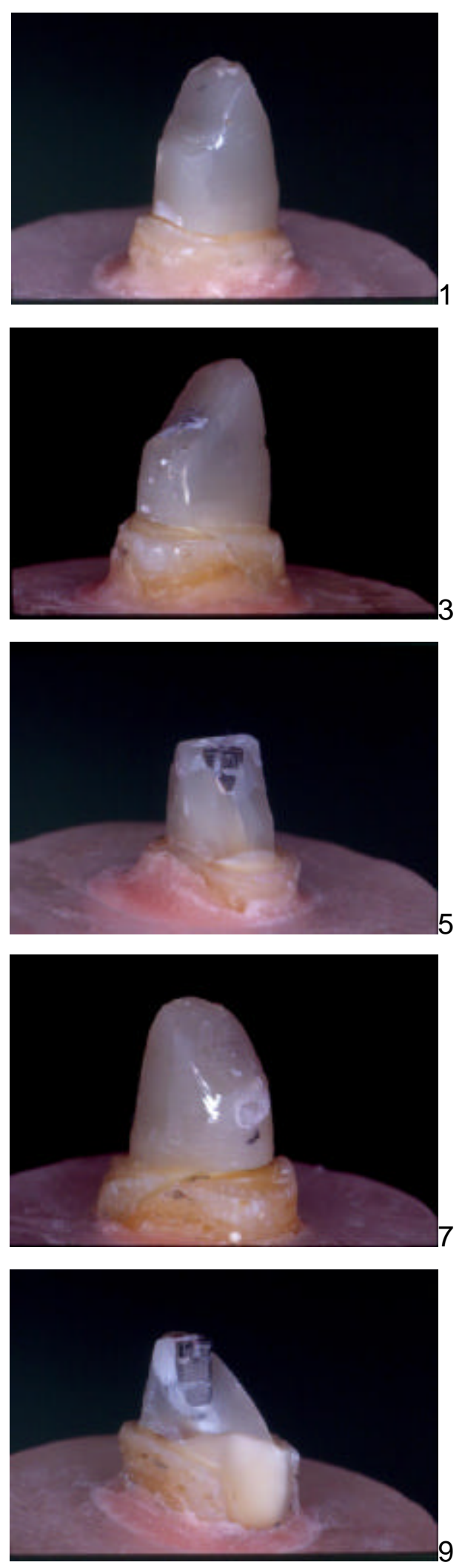

FIGURA 13 - Z-250 sem remanescente coronal
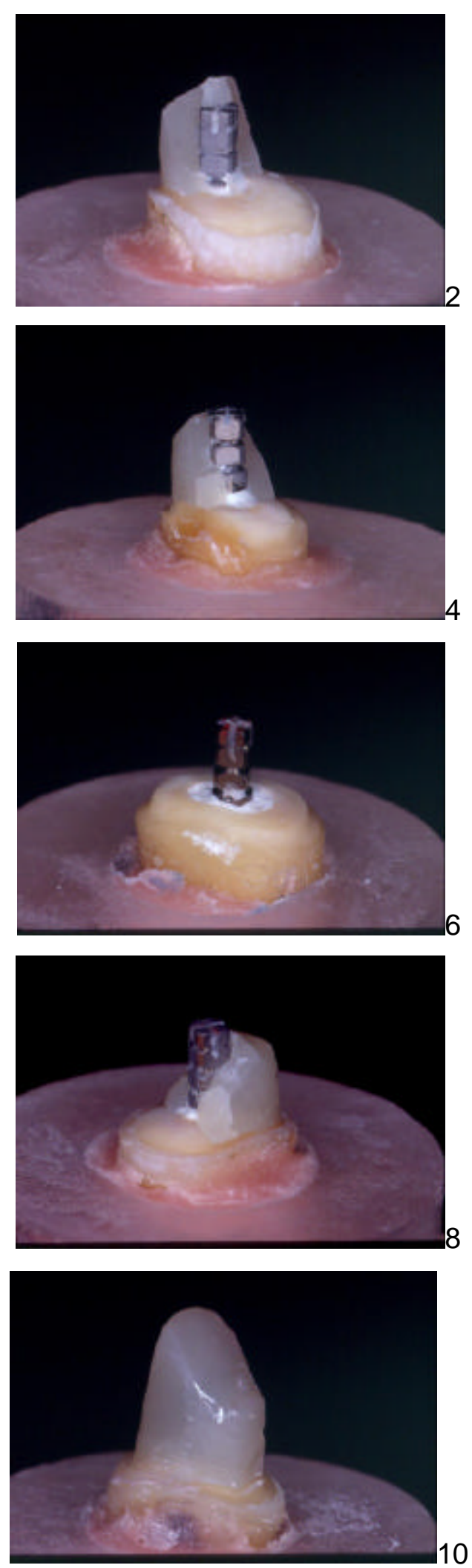

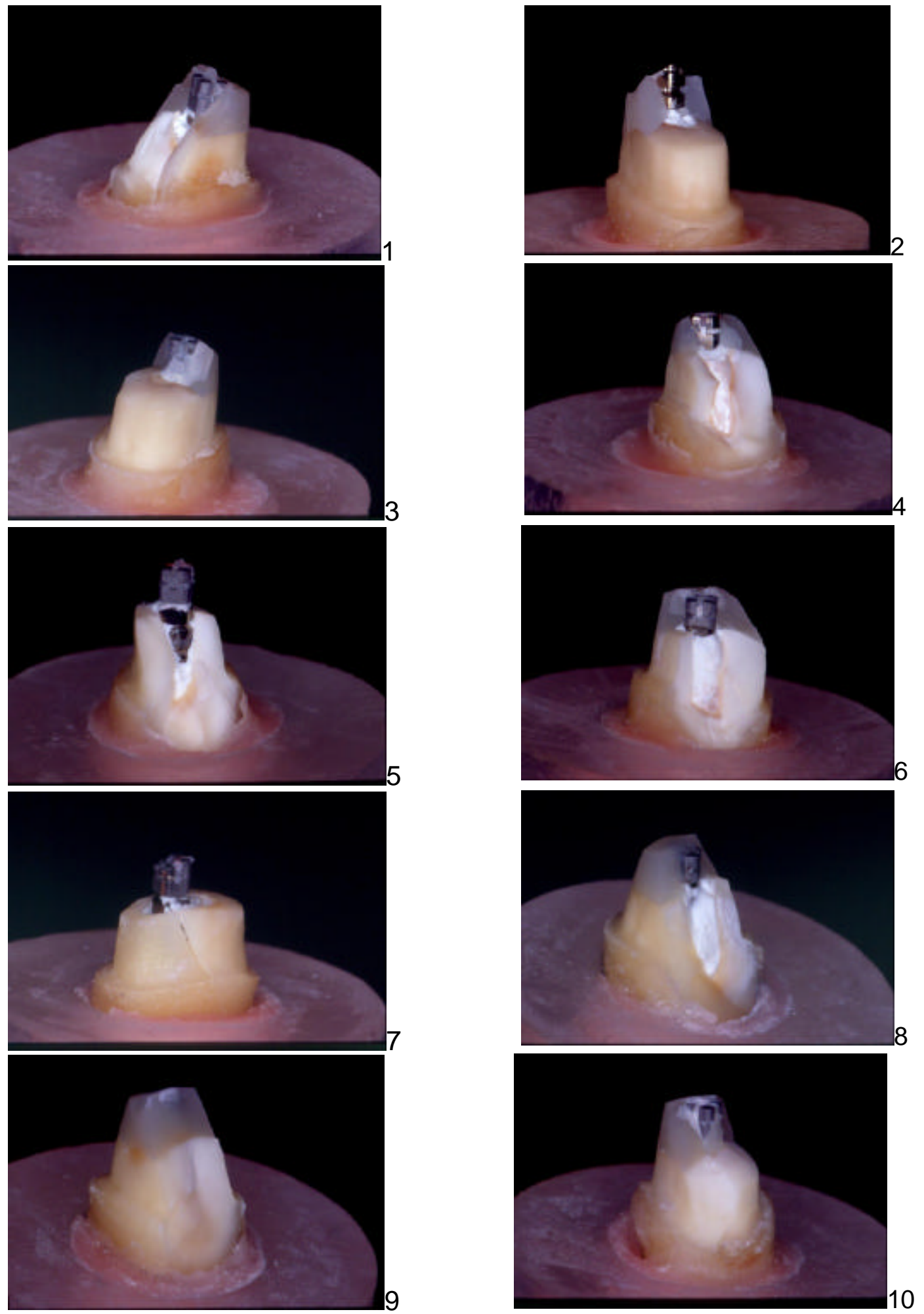

FIGURA 14 - Z-250 com remanescente coronal 
REFERÊNCIAS 


\section{REFERÊNCIAS}

1. ABDALLA, A. I.; ALHADAINY, H. A. 2-years clinical evaluation of class I posterior composites. Amer. J. Dent., v.9, n.4, p.150-2, Aug., 1996.

2. AKKAYAN. B. et al. Resístanse to fracture of endodontically treated restored with different post systems. J. prosth. Dent., v.87,n.4, p.431-7, Apr. 2002.

3. ANUSAVICE, K. J. Resinas para restauração. In: . Phillips materiais dentários. Rio de Janeiro, Guanabara Koogan, 1998. p.161-85.

4. ASSIF, D.; GORFIL, C. Biomechanical considerations in restoring endodontically treated teeth. J. prosth. Dent., v.71, n.6, p.565-7, June 1994.

5. ASSIF, D. et al. Effect of post design on resistance to fracture of endodontically treated teeth with complete crowns. J. prosth. Dent., v.69, n.1, p.36-40, Jan. 1993.

6. ASSIF, D. et al. Photoelastic analysis of stress transfer by endodontically treated teeth to the supporting structure using different restorative techniques. J. prosth. Dent., v.61, n.6, p.6768, Jan. 1989. 
7. AUSIELLO, P. et al. Fracture resistance of endodontically-treated premolars adhesively restored. Amer. J. Dent., v.10, n.5, p.23741, Oct. 1997.

8. BAHARAV, $\mathrm{H}$. et al. Effect of irradiation time on tensile properties of stiffness and strength of composites. J. prosth. Dent., v.77, n.5, p.471-4, May 1997.

9. BARABAN, D. J. A simplified method for making posts and cores. J. prosth. Dent., v.24, n.3, p.287-97, Sept. 1970.

10. BARABAN, D. J. Immediate restoration of pulpless teeth. J. prosth. Dent., v.28, n.6, p.607-12, Dec. 1972.

11. BARKHORDAR, R. A.; RADKE, R.; ABBASI, J. Effect of metal collars on resistance of endodontically treated teeth to root fracture. J. prosth. Dent., v.61, n.6, p.676-8, June 1989.

12. BEN-AMAR, A. et al. Retention of prefabricated post with dental adhesive and composite. J. prosth. Dent., v.56, n.6, p.681-4, Dec. 1986.

13. BENDER, I. B.; FREEDLAND, J. B. Adult root fracture. J. Amer. dent. Ass., v.107, n.3, p.413-9, Sept. 1983.

14. BERGMAN, B. et al. Restorative and endodontic results after treatment with cast and cores. J. prosth. Dent., v.61, n.1, p.10-5, 1989. 
15. BEX, R.T. et al. Effect of dentinal bonded resin post-core preparations on resístanse to vertical fracture. J. prosth. Dent., v.67, n.1, p.768-72, 1992.

16. BRAVIN, R. V. Post reinforcement tested: the functional stress analysis of post reinforcement. J. Calif. dent Ass., v.4, p.66-96, 1976.

17. CAIlleteAU, J. G.; RIEGER, M. R.; AKIN, E. D. A comparison of intracanal stresses in a post-restored tooth utilizing fuüte element method. J. Endod., v.18, n.11, p.540-44, Nov. 1992.

18. CÂNDIDO, A. L. Avaliação da microdureza Knoop de três resinas compostas comparada a microdureza do esmalte de molares decíduos. Bauru, 2002. 130p. Dissertação (Mestrado) Faculdade de Odontologia de Bauru, Universidade de São Paulo.

19. CAPUTO, A. A.; STANDLEE, J. P. Pins and posts: why, when and how. Dent. Clin. N. Amer., v.20, n.2, p.299-311, Apr. 1976.

20. CARVALHO, R. M. et al. A review of polimerization contraction: the influence of stress development versus stress relief. Oper. Dent., v.21, n.1, p.17-24, Jan./Feb. 1996.

21. CARVALHO JÚNIOR, O. B. Avaliação in vitro da contração de polimerização e da rugosidade de 29 resinas compostas. Bauru, 2002. 206p. Tese (Doutorado) - Faculdade de Odontologia de Bauru, Universidade de São Paulo.

22. CHAIN, M. C. Como polimerizar uma resina composta. In: GUIA de compras dental gaucho. Porto Alegre: Dental Gaúcho, 2001. 
23. CHAN, R. W.; BRYANT, R. W. Post-core foundations for endodontically treated posterior teeth. J prosth. Dent., v.48, n.4, p.401, Oct. 1982.

24. $\mathrm{CHO}, \mathrm{G}$. C. et al. Diametral and compressive strength of dental core materials. J. prosth. Dent., v.82, n.3, p.272-6, Sept. 1999.

25. CHRISTENSEN, G. J. Posts: necessary or unnecessary? J. Amer. dent. Ass., v.127, p.1522-58, Oct. 1996.

26. CHRISTIAN, G. W. et al. Post core restoration in endodontically treated posterior teeth. J. Endod., v.7, p.182-5, 1981.

27. CHRISTY, J. M.; PIPKO, D. J. Fabrication of a dual-post veneer crown. J. Amer. dent. Ass., v.75, n.6, p.1419-25, Dec. 1967.

28. COHEN, B. I. et al. Comparison of the retentive properties of two hollow-tube post systems to those of a solid post design. J. prosth. Dent., v.78, n.6, p.560-5, 1993.

29. COHEN, B. I. et al. Four different core materials measured for fracture strength in combination with five different designs of endodontic posts. J. prosth. Dent., v.76, n.5, p.487-95, Nov. 1996.

30. COHEN, B. I. et al. Comparison of torsional forces at failure for seven endodontic post systems. J. prosth. Dent., v.74, n.4, p.350-7, 1996.

31. COHEN, B. I. et al. Fracture strength of three different core materials in combination with three different endodontic posts. Int. J. Prosthodont., v.7, p.178-82, 1994. 
32. COHEN, B. I. et al. Pilot study comparing the photoelastic stress distribution for four endodontic post systems. J. oral. Rehab., v.23, p.679-85, Nov. 1996.

33. COHEN, B. I. et al. Fracture strengths of three core restorative materials supported with or without a pre-fabricated split-shank post. J. prosth. Dent., v.78, n.6, p.560-4, 1997.

34. COHEN, B. I. et al. Retention of a core material supported by three post designs. J. prosth. Dent., v.83, n.6, p.624-8, 2000.

35. CRUZ, J.; MAI, H.; SHELLARD, E. Rockwell hardness of hybrid composites with the optilux 501. J. dent. Res., v.79, p.446, 2000. Abstract n. 2420. Special issue.

36. DEUTSCH, A. S. et al. Prefabricated dowels: A literature review. J. prosth. Dent., v.49, n.4, p.498-503, Apr. 1983.

37. DEUTSCH, A. S. et al. Root fracture and the design of prefabricated posts. J. prosth. Dent., v. 53, n.1, p.12-4, Jan. 1985.

38. DEWALD, J. P. The use of extracted teeth for in vitro bonding studies: a review of infection control considerations. Dent. Mat., v.13, n.2, p.74-81, Mar. 1997.

39. ECKERBOM, M.; MAGNUSSON, T. Restoring endodontically treated teeth: A survey of current opinions among board-certified prosthodontics andgeneral dental practitioners in Sweden. Int. J. Prosthodont., v.14, n.3 p.245-9, 2001. 
40. FARAH, J. W.; KRAIG, R. G. Stress analysis of three marinal configurations of full posterior crowns by three-dimensional photoelasticity. J. dent. Res., n.21, v.5, p.1219-25, 1974.

41. FEDERICK, D. R. An application of the dowel and composite resin core technique. J. prosth. Dent., v.32, n.4, p.420-4, Oct. 1974.

42. FERNANDES, A. S.; DESSAI, G. S. Factors affecting the fracture resistance of post-core reconstructed teeth: a review. Int. J. Prosthodont., v.14, n.4, p.355-63, 2001.

43. FRAGA, R. C. et al. Fracture resistance of endodontically treated roots after restoration. J. oral Rehab., v.25, n.11, p.809-13, Nov. 1998.

44. GATEAU, P.; SABEK, M.; DAILEY, B. Fatigue testing and microscopic evaluation of post and core restoration under artificial crowns. J. prosth. Dent., v.82, n.3, p.341-7, Sept. 1999.

45. GELFAND, M.; GOLDMAN, M.; SUNDERMAN, E. J. Effect of complete veneer crowns on the compressive strength of endodontically treated posterior teeth. J. prosth. Dent., v. 52, p.635-8,1984.

46. GUTMANN, J. L. The dentin-root complex: anatomic and biologic considerations in restoring endodontically treated teeth. J. prosth. Dent., v.67, n.4, p.458-67, Apr. 1992.

47. GUZY, G. E.; NICHOLLS, J. I. In vitro comparison of intact endodontically treated teeth with and without endo-post reinforcement J. prosth. Dent., v.42, n.1, p.39-44, July 1979. 
48. HALPERN, G. B. Restoration of endodontically treated teeth. A conservative approach Symposium on restorative dentistry. Dent. Clin. N. Amer., v.29, n.2, p.293-303, Apr. 1985.

49. HENRY, H. W. et al. Fracture behavior of human mandibular incisors following endodontic treatment and porcelain veneer restoration. Int. J. Prosthodont., v.14, n.3, p.260-4, 2001.

50. HENRY, P. J. Photoelastic analysis for post core restorations. Aust. dent. J., v.22, n.3, p.157-9, June 1977.

51. HERNANDEZ, R. et al. Resistance to fracture of endodontically treated premolars restored with newgeneration dentin bonding system. Int. Endod. J., v.27, p.281-4, 1994.

52. HEYDECKE, G.; PETERS, M. C. The restoration of endodontically treated, single-rooted teeth with cast or direct posts and cores: a systematic review. J. prosth. Dent., v.87, n.4, p.380-6, Apr. 2002.

53. HOAG, E. P.; DWYER, T. G. A comparative evaluation of three post and core techniques. J. prosth. Dent., v.47, n.2, p.177-81, Feb. 1982.

54. HOLMES, D. C.; DIAZ-ARNOLD, A. M.; LEARY, J. M. Influence of post dimension on stress distribution in dentin. J. prosth. Dent., v.75, n.2, p.140-7, Feb. 1996.

55. HUANG, T. G.; SCHILDER, H.; NATHANSON, D. Effects of moisture content and endodontic treatment on some mechanical properties of human dentin. J. Endod., v.18, n.5, p.209-5, May 1992. 
56. HUNTER, A. J.; FEIGLIN, B.; WILLIAS, J. F. Effects of a post placement on endodontically treated teeth. J. prosth. Dent., v.62, n.8, p.166-72, Aug. 1989.

57. IRVIN, A. W. et al. Photoelastic analysis of stress induced from insertion of self-threading retentive pins. J. Prosth. Dent., v.53, p.311-6, 1985.

58. ISIDOR, F.; BRONDUM, K.; RAVNHOLT, G. The influence of post length and crown ferrule on the resistance to cyclic loading of bovine teeth prefabricated titanium post. Int. J. Prosthodont., v.12, n.1, p.79-82, 1999.

59. JOHNSON, J. K.; SAKAMURA, J. S. Dowel form and tensile force. J. prosth. Dent., v.40, n.6, p.645-9, Dec. 1978.

60. JOHNSON, J. K. et al. Evaluation and restoration of endodontically treated posterior teeth. J. Amer. dent Ass., v.93, n.3, p.597-605, Sept. 1976.

61. KAHN, F. H. et al. Comparison of fatigue for three prefabricated threaded post systems. J. prosth. Dent., v.75, n.2, p.148-53, Feb. 1995.

62. KANTOR, M. E.; PINES, M. S. A. Comparative study of restorative techniques for pulpless teeth. J. prosth. Dent., v.38, n.4 p.405-12, Oct. 1977.

63. KAYSER, A. F.; LEEMPOEL, P. J. B.; SNOEK, P. A. The metal post and composite core combination. J. oral. Rehab., v.14, n.1 p.311, 1987. 
64. KEYF, F.; SAHIN, E. Retentive properties of three post-core systems. Aust. dent. J., Saint Leonards, v.39, n.1, p.20-4, Jan. 1994.

65. KING, P. A.; SETCHELL, D. J. Analisys in vitro evaluation of a prototype CFRC prefabricated post developed for the restoration of pulpless teeth. J. oral Rehab., v.39, n.1, p.599-609, 1990.

66. LAMBRECHTS, $P$. et al. Evaluation of clinical performance for posterior composite resins and dentin adhesives. Oper. Dent., v.12, p.53-78, 1987.

67. LEARY, J. M.; AQUILINO-ASSWARE, C. W. An evaluation of post strength within the elastic limits of dentin. J. prosth. Dent., v.57, p.277-81, 1987.

68. LEVARTOVSKY, S. et al. A comparison of the diametral tensile strength, the flexural strength, and the compressive strength of two new core materials to a silver alloy-reinforcedglass-ionomer material. J. prosth. Dent., v.72, p.481-85, 1994.

69. LINDE, L. A. The use of composites as core material in root-filled teeth. Swed dent J., v.8, p.209-16, 1984.

70. LINDE, L. A. The use of composite resins in combination with anchorage posts as core material in endodontically treated teeth: clinical aspects of the technique. Quintessence Int., v.24, n.2, p.115-22, Feb. 1993.

71. LONEY, R. W.; KOTOWICS, W. E.; McDOWELL, G. C. Threedimension photoelastic stress analysis of the ferrule effect in cast post and cores. J. prosth. Dent., v.63, n.5, p.506-46, 1990. 
72. LYONS, M. F. A preliminary electromyographic study of bite force and jaw-closing muscle fatigue in human subjects with advanced tooth wear. J. oral Rehab., v.17, p.311-18, 1990.

73. MC DONALD, A. V.; KING, P. A.; SETCHELL, D. J. An in vitro study to compare impact fracture resistance of intact root-treated teeth. Int. Endod. J., v.23, p.304-12, 1990.

74. MCLEAN, A. Criteria for predictably restorable endodontically treated tooth. J. Canad. dent. Ass., v.64, n.9, p.652-6, Oct. 1998.

75. MCLEAN, A. Predictability of restoring endodontically trated teeth. J. Canad. dent. Ass., v.64, n.11, p.782-7, Dec. 1998.

76. MANNING, K. E. et al. Factors to consider for predictable post and core build-ups of endodontically treated teeth. Part I: Basic theoretical concepts. J. Canad. dent. Ass., v.61, n.8, p.685-95, Aug. 1995.

77. MANNING, K. E. et al. Factors to consider for predictable post and core build-ups of endodontically treated teeth. Part II: Clinical application of basic concepts. J. Canad. dent. Ass., v.61, n.8, p.696-706, Aug. 1995.

78. MARKLEY, M. R. Pin reinforcement and retention of amalgam foudations and restorations. J. Amer. dent. Ass., v.55, p.675-9, 1958.

79. MARTINEZ-INSUA, A. et al. Comparison of fracture resistances of pulpless teeth restored wth a cast post and core or carbon-fiber post with a composite core. J. prosth. Dent., v.80, n.5, p.527-32, Nov. 1998. 
80. MATTISON, G. D. Photoelastic stress analysis of cast-gold endodontic posts. J. prosth. Dent., v.48, n.4, p.407-11, Oct. 1982.

81. MENTINK, A. G. B. et al. Porosity in resin composite core restorations: the effect of manipulative techniques. Quintessence. Int., v.26, n.11, p.811-5, Nov. 1995.

82. MILLER, A. W. Direct pattern techinique for post and cores. J. prosth. Dent., v.40, n.4, p.327-9, 1978.

83. MONDELLI, J. et al. Fracture strength of human teeth with cavity preparations. J. prosth. Dent., v.43, n.4, p.419-22, Apr. 1980.

84. MORGANO, S. M. Restoration of pulpless teeth: application of traditional principles in present and future contexls. J. prosth. Dent., v.75, n.4, p.375-80, Apr. 1996.

85. MORGANO, S. M.; BRACKETT, S. E. Foundation restorations in fixed prosthodontics: current knowledge and future needs. J. prosth. Dent., v.82, n.6, p.643-57, Dec. 1999.

86. MORGANO, S.; MILOT, P. Clinical success of cast metal post and cores. J. prosth. Dent., v.69, n.1, p.11-6, 1993.

87. OLIVEIRA, F. C.; DENEHY, G. E.; BOYER, D. B. Fracture resistance of endodontically prepared teeth using various restorative materials. J. Amer dent. Ass., v.115, n.7, p.57-60, July 1987.

88. PEREL, M. L.; MUROFF, F. I. Clinical criteria for posts and cores. J. prosth. Dent., v.28, n.4, p.405-11, Oct. 1972. 
89. PETERS, M. C. R. B. et al. Stress analysis of a tooth restored with a post and core. J. dent. Res., v.62, n.2, p.760-3, June. 1983.

90. PEUTZFELD, A.; ASMUSSEN, E. Flexural and fatigue strengths of root canal posts. Scand. J. dent. Res., v.98, p.550-7, 1990.

91. PILO, R. Residual dentin thickness in mandibular premolars prepared withgatesglidden and ParaPost drills. J. prosth. Dent., v.83, n.6, p.617-23, June 2000.

92. PLASMANS, P. J. J. M. et al. In vitro comparison of dowel and core techniques for endodontically treated molars. J. Endod., v.12, p.382-7, 1986.

93. PLASMANS, P. J. J. M. et al. In vitro resistance of composite resin dowel and cores. J. Endod., v.14, p.300-4, 1988.

94. RADKE, R. A.; BARKHODAR, R. A.; PODESTA, R. E. Retention of cast endodontic posts: comparison of cementing agents. J. prosth. Dent., v.59, n.3, p.318-20. Mar. 1988.

95. RAIDEN, G. C; GENDELMAN, H. Effect of dowel space preparation on the apical seal of root canal fillings. Endod. dent. Traumat., v.10, p.109-12, July 1994.

96. RAYGOT, C. G. Fracture resistance and primary failure mode of endodontically treated teeth restored with a carbon fiber-reinforced resin post system In vitro. Int. J. Prosthodont., v.14, n.2, p.141-5, 2001. 
97. REAGAN, S. E. et al. Effects of cyclic loading on selected post and core systems. Quintessence Int., v.30, n.1, p.61-7, 1999.

98. ROBBINS, J. W. Guidelines for the restoration of endodontically treated teeth. J. Amer. dent. Ass., v.120, n.5, p.558-6, May 1990.

99. ROBBINS, J. W. et al. Fracture resistance of endodontically treated cuspids. J. Amer. dent. Ass., v.6, n.1, p.159-61, 1993.

100. ROLF, K. C.; PARKER, M. W.; PELLEU, G. B. Stress analysis of five prefabricated endodontic dowel designs: a photoelastic study. Oper. Dent., v.17, p.86-72, May/June 1992.

101. ROSEN, H. Operative procedures on mutilated endodontically treated teeth. J. prosth. Dent., v.11, p.973-86, 1961.

102. SEDGLEY, C. M.; MESSER, H. H. Are endodontically treated teeth more brittle? J. Endod., v.18, n.7, p.332-5, July 1992.

103. SIDOLI, G. E.; KING, P. A.; SETCHELL, D. J. An in vitro evaluation of carbon fiber-based post and core system. J. prosth. Dent., v.78, n.1, p.5-9, July 1997.

104. SILVERSTEIN, W. H. The reinforcement of weakened pulpless teeth. J. prosth. Dent., v.14, p.372-81, 1964.

105. SIRIMAI, S.; RIIS, D.N.; MORGANO, S. M. An in vitro study of the fracture resistance and the incidence of vertical root fracture of pulpless teeth restored with six post-and-core systems. J. prosth. Dent., v.81, n.3, p.262-9, Mar. 1999. 
106. SMITH, C. T.; SCHUMAN, N. Restoration of endodontically treated teeth: guide for the restorative dentist. Quintessence Int., v.28, n.7, p.457-62, 1997.

107. SMITH, C. T.; SCHUMAN, N. J.; WASSON, W. Biomechanical criteria for evaluating prefabricated post-and-core systems: aguide for the restorative dentist. Quintessence Int., v.29, n.5. p.305-12, May 1998.

108. SORENSEN, J. A. Preservation of tooth structure. J. Calif. Dent. Ass., v.11 p.15-21, Nov. 1988.

109. SORENSEN, J. A.; ENGELMAN, M. J. Effect of post adaptation on fracture resistance of endodontically treated teeth. J. prosth. Dent., v.64, n.4, p.419-24, Oct. 1990.

110. SORENSEN, J. A.; ENGELMAN, M. J. Ferrule design and fracture resistance of endodontically treated teeth. J. prosth. Dent., v.63, n.5, p.529-36, May 1990.

111. SORENSEN, J. A.; MARTINOFF, J. T. Intracoronal reinforcement and coronal coverage: a study of endodontically treated teeth. J. prosth. Dent., v.51, n.6, p.780-4, June 1984.

112. SORENSEN, J. A.; MARTINOFF, J. T. Clinical significant factors in dowel design. J. prosth. Dent., v.52, n.1, p.28-35, July 1984.

113. SORENSEN, J. A. et al. Selection criteria for post and core materials in restoration of endodontically treated teeth. Dent. Mat., p.67-84, 2001. 
114. SORNKUL, E.; STANNARD, J. T. Strength of roots before and after endodontic treatment and restoration. J. Endod., v.18, n.9, p.4403, Sept. 1992.

115. STAHL, G. J.; O'NEAL, R. B. The composite resin dowel and core. J. prosth. Dent., v.33, n.6, p.642-8, June 1975.

116. STANDLEE, J. P. et al. Analysis of stress distribution by endodontic posts. Oral Surg., v.33, n.6, p.953-60, June 1972.

117. STANDLEE, J. P.; CAPUTO-HANSON, E. C. Retention of endodontic dowels: effect of cement, dowel, lenght and design. J. prosth. Dent., v.39, p.401-5, 1978.

118. STERN, N.; HIRSHFELD, Z. Principles of preparing endodontically treated teeth for dowel and core restorations. J. prosth. Dent., v.30, n.2, p.162-5, Aug. 1973.

119. STOCKTON, L. W. Factors affecting retention of post systems: a literature review. J. prosth. Dent., v.81, n.4, p.380-5, Apr. 1999.

120. STOKES, A. N. Post crowns: a review. Int. Endod. J., v.20, p.1-7, 1987.

121. TALEGHANI, M.; LEINFELDER, K. F. Evaluation of a newglass ionomer cement with silver as a core buildup under a cast restoration. Reconstructive materials for endodontically treated teeth. J. prosth. Dent., v.57, n.4, p.446-9, Apr. 1988.

122. TALEGHANI, M.; MORGAN, R. W. Reconstructive materials for endodontically treated teeth. J. prosth. Dent., v.57, n.4, p.446-9, Apr. 1987. 
123. TJAN, A. H. L.; WHANG, S. B. Resistance to root fracture of dowel channels with various thicknesses of buccal dentin walls. J. prosth. Dent., v.53, n.4, p.496-500, Apr. 1985.

124. TORBJÖRNER, A.; KARLSSON, S.; ODMAN, P. A. Survival rate and failure characteristics for two post designs. J. prosth. Dent., v.73, n.5, p.439-44, May 1995.

125. TRABERT, K. C.; CAPUT, A. A.; ABOU-RASS, M. Tooth fracture-a comparison of endodontic and restorative treatments. J. Endod., v.4, n.11, p.341-5, Nov. 1978.

126. TROPE, M.; TRONSTAD, L. Resistance to fracture of endodontically treated premolars restored withglass ionomer cement or acid etch composite resin. J. prosth. Dent., v.17, n.6, p.257-9, June 1991.

127. TROPE, M.; MALTZ, D. O.; TRONSTAD, L. Resistance to fracture of restored endodontically treated teeth. Endod. dent. Traumat., v.1, n.3, p.108-11, June 1985.

128. VALLE, A. L. do. Avaliação do desajuste vertical, resistência à tração e compressão de núcleos metálicos fundidos, cimentados com cimentos de fosfato de zinco e resinoso em condutos tratados ou não com ácido fosfórico. Bauru 2000. 191p. (Tese Livre - Docência) - Faculdade de Odontologia de Bauru, Universidade de São Paulo.

129. VERSLUIS, A. et al. Do an incremental filling technique reduce polymerization shrinkage stresses? J. dent. Res., n.3, p.871-8, Mar. 1996. 
130. WEINE, F. S.; WAX, A. H.; WENCKUS, C. S. Retrospective study of tapered, smooth post systems in place for 10 years or more. J. Endod., v.17, n.6, p.293-7, 1991.

131. YAMAN, P.; THORSTEINSSON, T. S. Effect of core materials on stress distribuition of post. J. prosth. Dent., v.68, p.416-20, 1992.

132. ZALKIND, M.; HOCHMAN, N. Esthetic considerations in restoring endodontically treated teeth with posts and cores. J. prosth. Dent., v.79, n.6, p.702-5, June 1998. 
ABSTRACT 


\section{ABSTRACT}

\section{FRACTURE STRENGTH ASSESSMENT OF TEETH ENDODONTICALLY TREATED, RESTORED WITH PREFABRICATED POSTS AND COMPOUND RESINS, AND VARYING AMOUNT OF REMAINING CORONAL DENTAL STRUCTURE}

The aim of this study was to evaluate the remaining coronal dental structure influence of endodontically treated teeth, restored with prefabricated posts and two different types of resin filling cores, a dual cure resin (Enforce Core) and a photopolymerizing resin (Z-250). 40 extracted upper canine human teeth were used, divided into four groups of 10 specimens each: Group I - with coronal dental structure of $3 \mathrm{~mm}$ restored with Enforce Core; Group II - with coronal dental structure of $3 \mathrm{~mm}$ restored with Z-250; Group III - without any remaining coronal dental structure restored with Enforce Core; Group IV - without any remaining coronal dental structure restored with Z-250. After the complete restoration, the teeth were taken to a universal test machine, and then submitted to compression forces at $45^{\circ}$, until reaching the fracture of the restoration. The analysis of the results (ANOVA, p>0,05) showed no statistically significant difference between the teeth with or without coronal dental structure. In relation to the material used for the coronal filling, there has been a statistically significant difference. Higher fracture strength values were found in the group restored with photopolymerizing resin.

Keywords: Strength, post, core, compound resins. 